\title{
SISTEMA AGROINDUSTRIAL BRASILEIRO DA CARNE BOVINA: ANÁLISE DO IMPACTO DAS MUDANÇAS INSTITUCIONAIS EUROPÉIAS SOBRE A ESTRUTURA DE GOVERNANÇA
}

\author{
Mariusa Momenti Pitelli
}

Dissertação apresentada à Escola Superior de Agricultura "Luiz de Queiroz", Universidade de São Paulo, para obtenção do Título de Mestre em Ciências, Área de Concentração: Economia Aplicada.

P I R A C I C A B A

Estado de São Paulo - Brasil

Dezembro - 2004 


\title{
SISTEMA AGROINDUSTRIAL BRASILEIRO DA CARNE BOVINA: ANÁLISE DO IMPACTO DAS MUDANÇAS INSTITUCIONAIS EUROPÉIAS SOBRE A ESTRUTURA DE GOVERNANÇA
}

\author{
Mariusa Momenti Pitelli \\ Bacharel em Ciências Econômicas
}

Orientador: Profa. Dra. MÁRCIA AZANHA FERRAZ DIAS DE MORAES

\begin{abstract}
Dissertação apresentada à Escola Superior de Agricultura "Luiz de Queiroz", Universidade de São Paulo, para obtenção do Título de Mestre em Ciências, Área de Concentração: Economia Aplicada.
\end{abstract}

P I R A C I C A B A

Estado de São Paulo - Brasil

Dezembro - 2004 


\section{Dados Internacionais de Catalogação na Publicação (CIP) DIVISÃO DE BIBLIOTECA E DOCUMENTAÇÃO - ESALQ/USP}

\section{Pitelli, Mariusa Momenti}

Sistema agroindustrial brasileiro da carne bovina: análise do impacto das mudanças institucionais européias sobre a estrutura de governança / Mariusa Momenti Pitelli. - Piracicaba, 2004.

$$
160 \mathrm{p} \text {. }
$$

Dissertação (Mestrado) - - Escola Superior de Agricultura Luiz de Queiroz, 2004.

Bibliografia.

1. Carne bovina - Aspecto econômico 2. Comportamento do consumidor 3. Custo de transação 4. Instituição I. Título

CDD 338.4766492 
DEDICO

Aos meus avós, Arlindo Momenti e Irma Bianconi Momenti, e à minha mãe Marli Aparecida Momenti, pelo amor incondicional que sempre recebi e pelos sacrifícios que tiveram que passar em prol da minha formação. 


\section{AGRADECIMENTOS}

À minha família, especialmente aos meus primos e irmãos, que sempre estiveram presentes nos meus momentos de alegria e de maiores dificuldades, me apoiando em todas as decisões.

À Prof. Márcia Azanha Ferraz Dias de Moraes, pela orientação dedicada e competente, pelos incentivos constantes e pela paciência e compreensão durante todo o período de elaboração desta dissertação.

Aos Profs. Alexandre Lahóz Mendonça de Barros, Pedro Valentim Marques e Sílvia Helena Galvão de Miranda pelas críticas e sugestões apresentadas por ocasião do exame de qualificação.

Ao CNPq, pelo auxílio e incentivo através da concessão da bolsa para o curso de mestrado.

Aos professores do Departamento de Economia, Sociologia e Administração da ESALQ/USP, pelos ensinamentos recebidos.

Aos funcionários do Departamento de Economia, Sociologia e Administração da ESALQ/USP, com especial destaque à Maielle, Helena e Ligiana.

Aos amigos e companheiros da Pós-Graduação em Economia Aplicada, Leila, Ana Maria, Renata, Luciane Schneider, Luciane Conte, Margarida, Sandra, Madalena, Piedade, Jonas, Moisés, e em especial a Cassiano, pelas palavras de ânimos em todos os momentos da realização do mestrado. 
E, por fim, a todas as demais pessoas que, direta ou indiretamente, contribuíram para a realização deste trabalho. 


\section{SUMÁRIO}

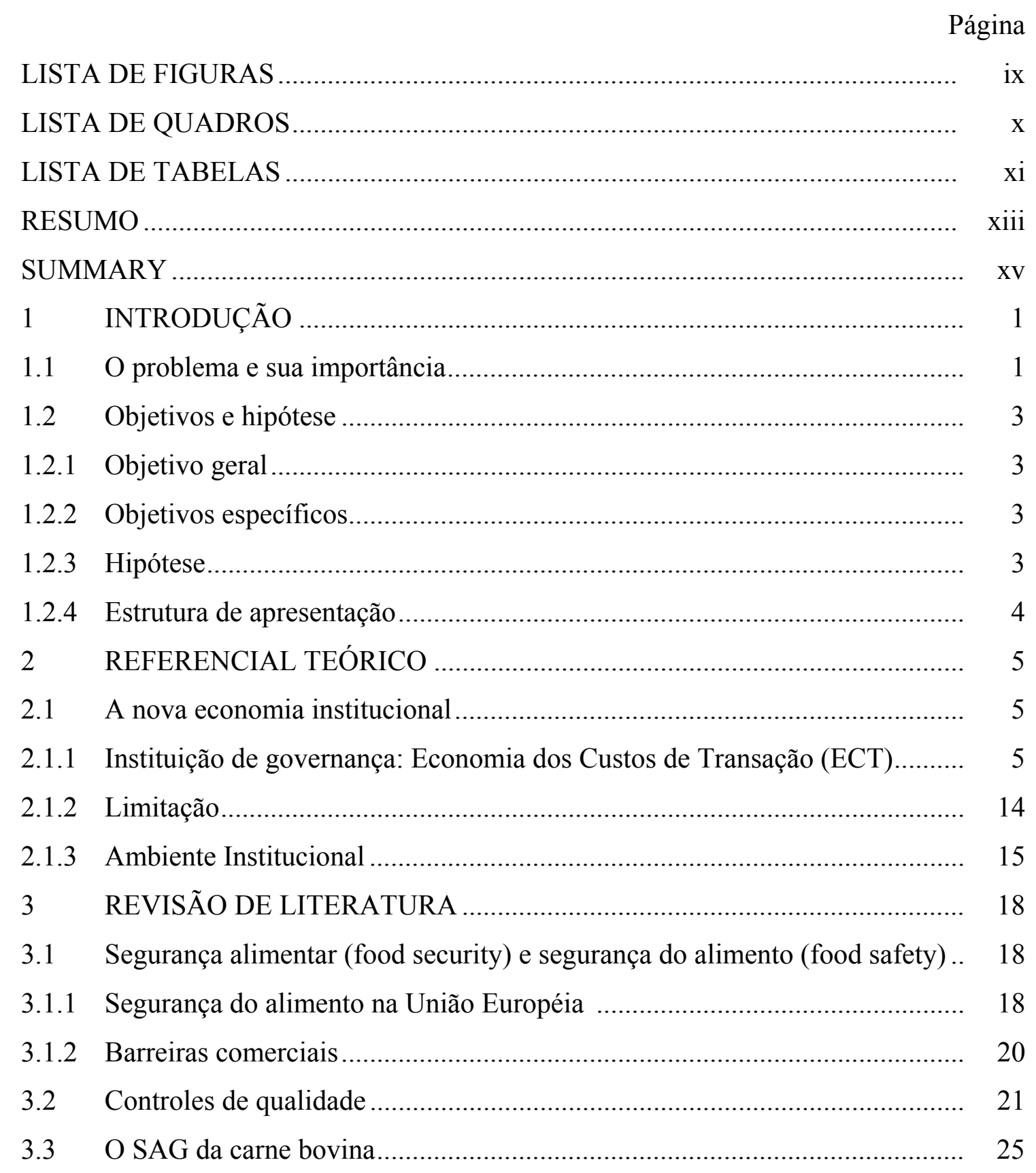


3.3.1 Panorama mundial do setor de carne bovina................................................. 25

3.3.1.1 Produção e consumo................................................................................ 25

3.3.1.2 Exportação e importação ............................................................................. 31

3.3.2 Panorama do SAG da carne bovina brasileira............................................. 35

3.3.2.1 Rebanho e abate ................................................................................ 42

3.3.2.2 Produção e consumo.................................................................................. 45

3.3.2.3 Exportação e importação ............................................................................ 46

3.3.2.4 Preços e margem de lucro ......................................................................... 54

3.3.2.5 Principais desafios .............................................................................. 57

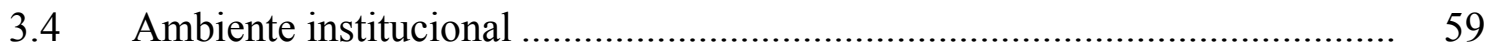

3.4.1 Análise das mudanças no ambiente institucional da União Européia............. 61

3.4.2 Análise das mudanças no ambiente institucional do Brasil ........................... 65

3.4.2.1 Clandestinidade da carne bovina no Brasil ................................................. 68

3.4.3 Sistema de inspeção sanitária ..................................................................... 72

3.5 Ambiente organizacional.................................................................. 76

3.5.1 Programas e alianças mercadológicas ............................................................. 76

3.6 Algumas evidências sobre a especificidade do ativo ....................................... 80

4 MATERIAL E MÉTODOS ………………....................................... 83

$4.1 \quad$ Obtenção de dados ........................................................................... 84

4.2 Estrutura e variáveis do questionário .......................................................... 87

4.2.1 Características gerais ........................................................................ 87

4.2.2 Aspectos institucionais e organizacionais .................................................... 88

4.2.3 Relação com o fornecedor ....................................................................... 89

4.2.4 Relação com o varejo ............................................................................. 90

4.2.5 Relação com clientes europeus ................................................................... 91

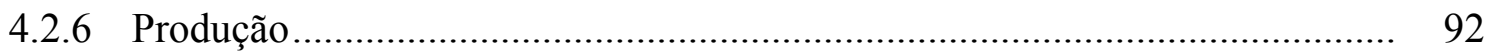

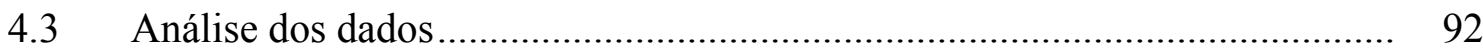

4.4 Problemas relativos à pesquisa.................................................................... 93

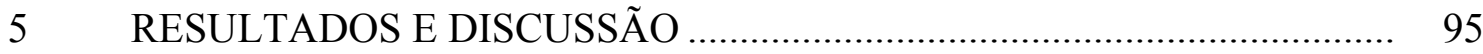

$5.1 \quad$ Características gerais............................................................................. 95 


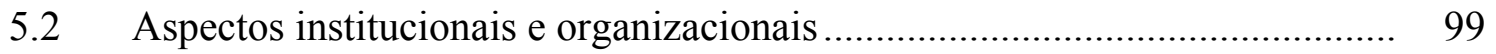

5.3 Relação com o fornecedor ................................................................... 110

5.4 Relação com o cliente interno ............................................................ 118

5.5 Relação com o cliente europeu................................................................ 122

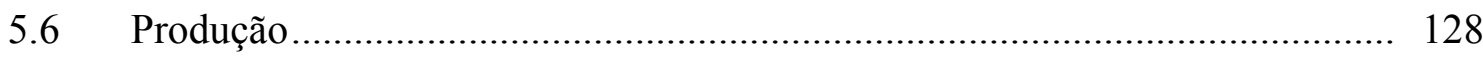

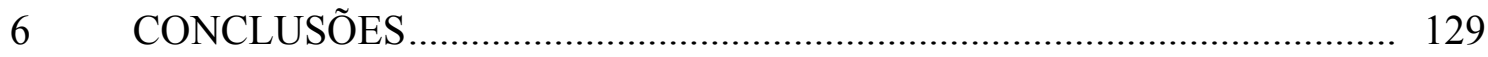

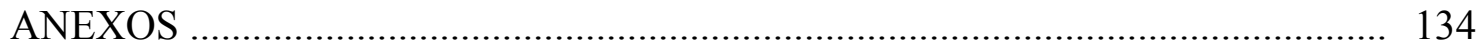

REFERÊNCIAS BIBLIOGRÁFICAS......................................................... 141

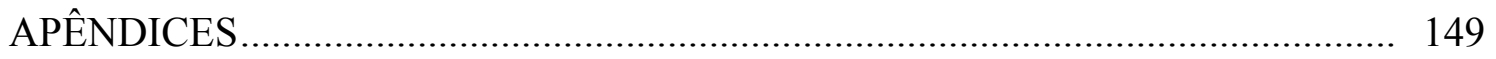




\section{LISTA DE FIGURAS}

Página

1 Formas de governança e especificidade do ativo ............................................. 13

2 O SAG da carne bovina................................................................................ 37

3 Evolução dos preços à vista médios internos do boi no Brasil R\$....................... 54

4 Evolução dos preços de exportação de carne bovina total US\$/T....................... 56 


\section{LISTA DE QUADROS}

Página

1 Atributos do processo de contratação.............................................................. 10

2 Alinhamento dos contratos: especificidade dos ativos e incerteza........................ 11

3 Quadro sinóptico de eventos que podem ter provocado mudanças no ambiente

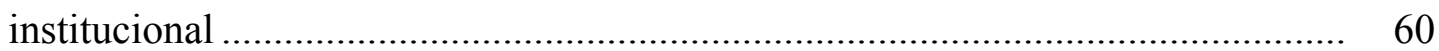

4 Principais atributos incidentes na cadeia de carne bovina ............................... 69

5 Peculiaridades dos sistemas de inspeção sanitária para carnes no Brasil.............. 73

6 Ambiente organizacional do sistema agroindustrial da carne bovina no Brasil.... 77

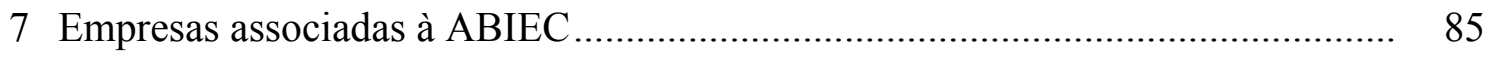

8 Dificuldades da empresa em atender o SISBOV ............................................. 106

9 Impactos da doença da vaca-louca sobre a estrutura/investimento na empresa ..... 108

10 Clientes europeus: exigências futuras e adicionais às existentes ........................ 109

11 Medidas tomadas pela empresa quanto à febre aftosa ..................................... 113

12 Variação dos fornecedores de boi ................................................................. 116

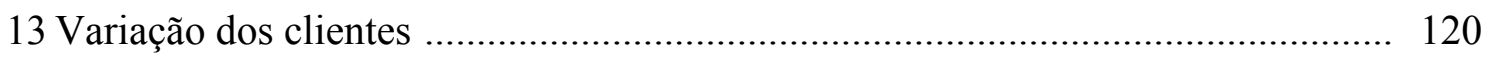




\section{LISTA DE TABELAS}

Página

1 Evolução da produção e consumo de carnes...................................................... 26

2 Evolução da produção de carne bovina (mil toneladas métricas equivalente

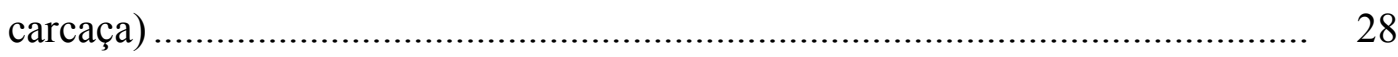

3 Evolução do consumo mundial de carne bovina (mil toneladas métricas

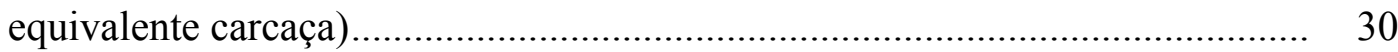

4 Evolução da exportação de carne bovina (mil toneladas métricas equivalente

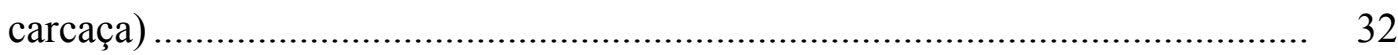

5 Evolução da importação de carne bovina (mil toneladas métricas equivalente

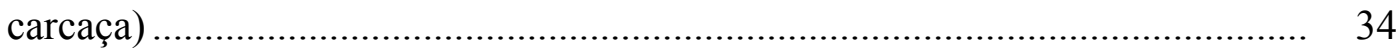

6 Evolução do rebanho bovino brasileiro por regiões e estados ........................... 43

7 Evolução da produção e consumo de carne bovina no Brasil............................. 45

8 Evolução da exportação e importação de carne bovina brasileira ....................... 46

9 Evolução da exportação brasileira de carne bovina (em peso e receita)............ 47

10 Evolução da exportação de carne bovina pelo Brasil por destino e tipo de produto (em toneladas métricas) ........................................................ 49

11 Evolução da importação de carne bovina pelo Brasil por origem e tipo de produto - em toneladas métricas ......................................................... 53

12 Estimativas da evolução do abate informal de bovinos .................................... 70

13 Data de fundação da empresa................................................................ 96

14 Mercado atendido e participação na produção em 2003 .................................. 96

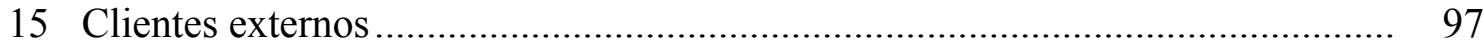

16 Participação dos clientes externos na quantidade exportada em 2003 ............... 98

17 Ano inicial de exportação aos clientes externos ........................................... 99 
18 Participação da empresa em Alianças Mercadológicas ou Programas de

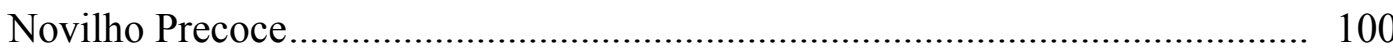

19 Responsável pela coordenação........................................................................ 101

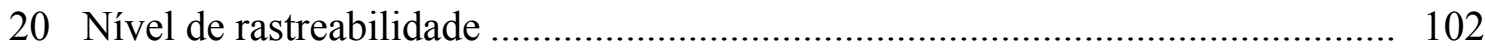

21 Programas de qualidade adotados pela empresa ............................................... 103

22 Ano de implementação das medidas de qualidade adotadas................................. 103

23 Programas de qualidade exigidos pelos europeus............................................. 104

24 Ano de exigência pela UE dos programas de qualidade ...................................... 105

25 Portaria com dificuldade em atender .............................................................. 106

26 Exigências dos clientes europeus quanto à matéria prima boi............................. 108

27 Forma de adquirir a matéria-prima boi ............................................................ 110

28 Criação de boi para fornecimento próprio ……………………………............. 112

29 Número de fornecedores da empresa ............................................................ 114

30 Compra de boi rastreado ...................................................................... 115

31 Incentivo dado pela empresa ao boi rastreado ……........................................ 115

32 Freqüência de compra de boi ........................................................................ 116

33 Incerteza quanto à matéria-prima boi.............................................................. 117

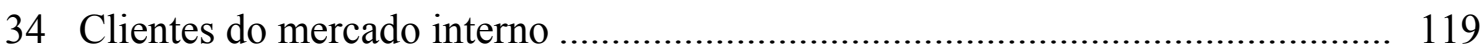

35 Freqüência de venda ao cliente interno.......................................................... 120

36 Incerteza quanto à venda da carne ao cliente interno........................................... 121

37 Tipo de carne exportada para a UE ............................................................. 122

38 Principais clientes europeus ........................................................................ 123

39 Opinião da empresa frigorífica sobre às exigências européias ............................ 124

40 Principais medidas adotadas para atender a essas exigências.............................. 125

41 Principais demandas em relação ao setor............................................................ 126

42 Freqüência de venda aos clientes europeus........................................................ 127

43 Incerteza quanto à venda da carne ao cliente europeu ....................................... 127 


\title{
SISTEMA AGROINDUSTRIAL BRASILEIRO DA CARNE BOVINA: ANÁLISE DO IMPACTO DAS MUDANÇAS INSTITUCIONAIS EUROPÉIAS SOBRE A ESTRUTURA DE GOVERNANÇA
}

\author{
Autor: MARIUSA MOMENTI PITELLI \\ Orientador: Profa. Dra. MÁRCIA AZANHA FERRAZ DIAS DE MORAES
}

\section{RESUMO}

O objeto de estudo desse trabalho é verificar os impactos das mudanças no ambiente institucional, europeu e nacional, em virtude das exigências do consumidor europeu quanto à qualidade do produto, sobre o Sistema Agroindustrial Bovino nacional.Utiliza-se como referencial teórico a Nova Economia Institucional (NEI), nas vertentes da Economia dos Custos de Transação (Williamson, 1989) e Economia Institucional (North, 1993). A hipótese central do trabalho considera que a alteração no ambiente institucional, devido ao crescimento das exigências do consumidor europeu, aumenta a especificidade do ativo, levando a adoção de uma estrutura de governança mais restrita como forma de reduzir os custos de transação. A partir das informações coletadas via questionários e entrevistas aplicadas às empresas frigoríficas exportadoras de carne bovina para a União Européia, concluiu-se que embora o aumento das exigências dos consumidores europeus tenha alterado o ambiente institucional do bloco, com conseqüentes alterações no ambiente institucional brasileiro, houve pouco impacto sobre a forma de governança das transações do SAG da carne bovina nacional. No que 
diz respeito à relação da indústria frigorífica exportadora com o fornecedor de boi, verificou-se que não há estabelecimentos de contratos nas transações. Contudo, este fato pode ser explicado pela criação de compromissos confiáveis entre as partes (fornecedores de boi e frigoríficos exportadores), e também pela falta de enforcement da rastreabilidade por parte da UE e do governo brasileiro (o que acaba por reduzir a especificidade do ativo da matéria-prima). Quanto à relação do frigorífico com seus compradores do mercado interno, rejeita-se a hipótese, pois prevalece um compromisso confiável entre as partes, sendo as transações conduzidas via mercado. No que se refere às relações dos frigoríficos exportadores com o mercado europeu, não se rejeita a hipótese, pois o aumento da especificidade dos ativos conduziu ao estabelecimento de contratos como forma de diminuir seus custos de transação. 


\title{
BRAZILIAN BEEF AGRO-INDUSTRIAL SYSTEM: ANALYSIS OF THE IMPACT OF EUROPEAN INSTUTITIONAL CHANGES ON THE GOVERNING FRAMEWORK
}

\author{
Author: MARIUSA MOMENTI PITELLI \\ Adviser: Prof. MÁRCIA AZANHA FERRAZ DIAS DE MORAES
}

\section{SUMMARY}

The aim of this study is to analyze the changes in the institutional environments, European and National, due to European consumers' requirements regarding the quality of products, about the National Beef Agro-Industrial System. It uses as theoretical references the New Institutional Economy (NEI), in its slopes of Economy of Cost of Transactions (Williamson, 1989) and Institutional Economy (North, 1993). The central hipothesis of the study considers that the changes in the institutional environment, due to the rise on requirements from European consumers, increases the peculiarity of the assets, leading to a more restrict governing framework as a way to reduce costs of transactions. Taking the data collected via questionairies and interviews made with the beef export slaughterhouses to the European Union, it is conluded that even though the rise on requirements from European consumers has changed the institutional environment of the block, with consequent changes in the Brazilian institutional environment, there has been little impact on the governing procedures of transactions of SAG of domestic beef. Regarding the beef export slaughterhouse industry, it was verified that there are no establishments of agreements for the 
transactions. However, this fact can be explained through the creation of reliable commitments between the parts (beef suppliers and slaughterhouses), and also by the lack of enforcement on traceability on the part of the European Union and the Brazilian government (which ends up reducing the peculiarity of the assets of the raw material). As for the relationship between the slaughterhouse and its consumers of the domestic market, the hypothesis is rejected, because what prevails is a realible commitment between the two parts, being the transactions conducted through the market. Regarding the relationship between the export slaughterhouse and the European market, the hypothesis is not rejected, because the rise on the peculiarity of assets leads to the establishment of agreements as a way to reduce the costs of transactions. 


\section{INTRODUÇÃO}

\subsection{O problema e sua importância}

O Sistema Agroindustrial (SAG) brasileiro da carne bovina está enfrentando um processo de evolução, em que as empresas, pressionadas pelo aumento de competição, estão se reestruturando para obterem ganhos de produtividade e qualidade. A cadeia bovina é composta por aproximadamente 1 milhão de pecuaristas de gado de corte, aproximadamente 1000 estabelecimentos da indústria de carnes, derivados e serviços de armazenagem, e aproximadamente 50 mil pontos varejistas (Bánkuti \& Azevedo, 2004a).

Em 2002, segundo dados do Instituto Brasileiro de Geografia e Estatística (IBGE, 2004), o rebanho bovino brasileiro era de 185,4 milhões de cabeças, sendo o maior rebanho comercial do mundo. Em 2003, a produção de carne bovina foi de 7,385

milhões de toneladas em equivalente carcaça ${ }^{1}$, e um consumo interno de 6,273 milhões de toneladas em equivalente carcaça segundo o Departamento de Agricultura dos Estados Unidos (USDA) (2004). Quanto ao comércio internacional, verificou-se uma importação de 63 mil toneladas em equivalente carcaça e uma exportação no valor de 1,175 milhões de toneladas em equivalente carcaça, com tendência crescente ao longo dos últimos anos, com previsão de tornar-se o maior exportador de carne bovina mundial em 2004 (Estados Unidos, 2004).

\footnotetext{
${ }^{1}$ Para conversão kg líquido para equivalente-carcaça usa-se: carne com osso = equivalente-carcaça (e.c), carne sem osso x 1,3 = e.c., carne industrializada x $2.5=$ e.c.
} 
Com o anúncio, em 1996, da relação entre a Encefalopatia Espongiforme Bovina (EEB) ou doença da "vaca-louca" e a doença em humanos Creutzfeldt-Jakob (CJD), aumentou-se a preocupação dos consumidores, principalmente o europeu, quanto à qualidade do produto e segurança do alimento. A partir disso, a União Européia introduziu leis sanitárias rigorosas aos produtos cárneos, exigindo dos países dos quais importa carnes que seus estabelecimentos produtores fossem por ela habilitados, devendo estes possuir um certificado de saúde pública emitido pela mesma, para então a comercialização ser aceita pelos estados membros (Brasil, 2001).

Como a UE é o maior importador de carne bovina brasileira ${ }^{2}$, aproximadamente $41 \%$ do valor total de carne bovina brasileira exportada em 2003 (ver anexo A), as exigências impostas trouxeram a necessidade de um processo de reestruturação ao longo de toda cadeia de carne bovina no Brasil, incluindo ações dos agentes privados e do governo, implicando alterações no ambiente institucional brasileiro para viabilizar a implantação de um sistema rigoroso de rastreabilidade dos produtos cárneos, visando a manutenção da segurança do alimento e aumento da competitividade, atendendo às exigências dos consumidores, principalmente externos.

Dessa forma, considerando-se que a União Européia é o maior mercado importador de carnes do Brasil e o fato deste país ter um grande potencial em expandir suas exportações, o estudo sobre os impactos das exigências dos consumidores europeus sobre a coordenação da cadeia produtiva e sobre as estruturas de governança torna-se tema relevante de trabalho.

${ }^{2}$ Cabe ressaltar que os dados de exportação de carne bovina brasileira utilizados na constatação da UE como maior importador de carne bovina brasileira foram extraídos do Sistema Alice, no Ministério do Desenvolvimento, Indústria e Comércio Exterior, através do Sistema Harmonizado (SH), cujos códigos estão descritos no anexo A. 


\subsection{Objetivos e hipótese}

\subsubsection{Objetivo geral}

O objetivo geral deste trabalho é verificar os impactos de mudanças no ambiente institucional, europeu e nacional sobre o Sistema Agroindustrial Brasileiro da carne Bovina, em virtude das exigências do consumidor europeu quanto à qualidade do produto.

\subsubsection{Objetivos específicos}

Têm-se como objetivos específicos:

- Caracterização do SAG da carne bovina bem como sua forma de coordenação atual;

- Identificar as principais exigências do consumidor europeu quanto à qualidade do produto;

- Apontar as principais mudanças relevantes no ambiente institucional e organizacional brasileiro e europeu com possíveis impactos ao SAG;

- Analisar se a variação de especificidade do ativo está alterando a estrutura de governança nos seguintes elos: frigorífico e fornecedor de boi; frigorífico e varejo (mercado interno); e, frigorífico e mercado europeu.

\subsubsection{Hipótese}

A hipótese deste trabalho é que a alteração no ambiente institucional, devido principalmente às exigências do consumidor europeu, aumenta a especificidade do ativo, 
levando a adoção de uma estrutura de governança mais restrita como forma de reduzir os custos de transação, em ambiente de oportunismo e racionalidade limitada.

\subsubsection{Estrutura de apresentação}

O objetivo e a hipótese deste trabalho estão descritos no capítulo 1. Em seguida é apresentado o referencial teórico que embasa o trabalho. No capítulo 3 apresenta-se a revisão de literatura. A metodologia é discutida no capítulo 4 e os resultados e discussões dos questionários são apresentados no capítulo 5. As conclusões são apresentadas no capítulo 6 . 


\section{REFERENCIAL TEÓRICO}

\subsection{A nova economia institucional}

O presente item apresenta os conceitos fundamentais para o trabalho sobre a Nova Economia das Instituições (NEI), que é composta por duas correntes, denominadas por Williamson (1989) de Ambiente Institucional e de Instituições de Governança.

A NEI tem como principal objetivo estudar o custo das transações como o indutor dos modos alternativos de governança dentro de um arcabouço analítico institucional.

Zylberzstajn (1995) afirma que existem pelo menos duas dimensões para lidar com a coordenação de sistemas de agribusiness. A primeira são os modos de governança resultantes das características das transações e a segunda são as características de governança resultantes do ambiente organizacional e institucional. Ambas interagem dando a forma final do modo de governança do sistema de agribusiness.

\subsubsection{Instituição de governança: economia dos custos de transação (ECT)}

A utilização da ECT como base analítica para o estudo de formas organizacionais da produção busca relacionar as dimensões típicas das transações com as formas de organização mais eficientes em termos de economia nos custos de transação e produção, em que a análise comparativa implica no contraste entre formas 
alternativas de organização, desde a realização da produção via mercado até o outro extremo, que é a verticalização.

Os custos de transação, segundo Arrow ${ }^{3}$, citado por Williamson (1989), são os custos de conduzir o sistema econômico, ou seja, os custos ex-ante de preparar, negociar e salvaguardar um acordo bem como os custos ex-post dos ajustamentos e adaptações que resultam, quando a execução de um contrato é afetada por falhas, erros, omissões e alterações inesperadas.

De acordo com Zylberzstajn (1995), o pressuposto básico da ECT é a existência de custos na utilização do sistema de preços como na condução de contratos intrafirma. O segundo pressuposto é de que as transações ocorrem em um ambiente institucional estruturado e que as instituições não são neutras, ou seja, interferem nos custos de transação, sendo o ambiente institucional correspondente ao sistema de normas (restrições informais, regras formais e sistemas de controle) que afetam o processo de transferência dos direitos de propriedade, exigindo recursos reais para operarem. $\mathrm{Ou}$ seja, o ambiente institucional é o locus de parâmetros de deslocamento que influencia na decisão sobre a forma organizacional de produção a ser adotada.

Governança de uma transação é a forma como as transações ocorrem. Existem três formas de governança: transacionar insumos e produto diretamente no mercado; forma híbrida, quando a firma adota contratos para se relacionar com outros agentes na transação; e forma hierárquica (verticalizada), em que a firma se encarrega de toda a produção e/ou comercialização de seus produtos. A ECT analisa qual estrutura de governança é mais eficiente através da consideração dos seus pressupostos comportamentais e das dimensões das transações.

Dessa forma, a governança de uma transação se faz através do uso de mecanismos apropriados para regular uma determinada transação, denominados de

\footnotetext{
${ }^{3}$ ARROW, R.H. The organization of economic activity: issues pertinent to choice of market versus nonmarket allocation. Washington: Governement Priting Office/US Joint Committee, 1969. (Analysis and evalution of public expecditure, 91)
} 
estruturas de governança (ou estruturas de gestão), que diferem em seus custos e competência, onde se devem alinhar as transações, tendo em vista a minimização de custos.

Em relação aos pressupostos comportamentais, dois são importantes para a ECT:

- Oportunismo: "é a busca do interesse próprio com dolo" (Williamson, 1989, p.57), incluindo mentiras, enganação e trapaças. Há o oportunismo ex-ante, quando uma parte não age eticamente antes de se efetivar a transação (resultando no fenômeno da seleção adversa) e, ex-post, em que o comportamento aético é verificado durante a vigência do contrato, conhecido como risco moral;

- Racionalidade Limitada: assume que os indivíduos agem racionalmente, mas de forma limitada. A obtenção de informações bem como a capacidade de processamento dessas informações são limitadas, o que torna os contratos incompletos, levando-os a incluir salvaguardas contratuais (Williamson, 1989).

Dessa forma, tanto o oportunismo quanto a racionalidade limitada estão relacionados à característica de incompletude dos contratos, sendo condições necessárias para ter custos de transação. Segundo Farina et al. (1997), na ECT, devido ao fato dos contratos serem incompletos, os custos de transação não são totalmente identificáveis ex-ante, ou seja, os custos de transação não podem se reduzir à elaboração do contrato, pois existem também custos ex-post. Como os indivíduos são racionais, mas limitadamente, e são oportunistas, leva-os a desenhar instituições que tenham a função de amenizar os problemas de adaptação entre eles e, dessa forma, viabilizar as transações. Assim considerando-se esses pressupostos comportamentais, emergem os custos de transação. 
No que se refere às dimensões das transações, são consideradas três pela ECT: especificidade de ativos, incerteza e freqüência.

Farina et al. (1997) afirmam que ativos específicos são aqueles que não podem ser reempregáveis sem perda de valor, tornando o investimento nesses ativos sujeito a riscos, gerando custos de transação. $\mathrm{O}$ valor da especificidade do ativo depende da continuidade da transação à qual ele é específico, gerando uma quase-renda.

Segundo Marshall, quase-renda é a quantidade obtida pelo vendedor de um bem ou serviço que supera seu custo de oportunidade, quando o bem ou serviço se encontra com a oferta fixa, ou seja, não há possibilidade de aumentá-la no curto prazo (Sandroni, 1999).

Williamson ${ }^{4}$ citado por Farina et al. (1997) define a quase-renda - também utilizando a terminologia marshalliana - como sendo a diferença entre o retorno de um ativo empregado em uma transação específica e seu retorno em outro emprego alternativo. Assim, quanto maior a especificidade, maior são os riscos de adaptação e, maiores os custos de transação, e maior quase renda.

A literatura descreve seis tipos de especificidade de ativos: a) especificidade locacional, em que a localização próxima de firmas de uma cadeia produtiva economiza custos de transporte e armazenagem; b) especificidades de ativos físicos, que se refere à especialização do ativo necessária para produzir o produto; c) especificidades de ativos humanos, que se refere à necessidade de investimentos em capital humano para exercer a atividade; d) ativos dedicados, que são investimentos feitos para clientes específicos; e) especificidade da marca, refere-se a investimentos feitos na marca de uma empresa; f) especificidade temporal, na qual o valor da transação está relacionado ao tempo em que ela é processada, muito importante no caso da negociação de produtos perecíveis.

${ }^{4}$ WILLIAMSON, O. Comparative economic organization: the analysis of discrete structural alternatives. Administrative Science Quartely, n.36, p.269-296, June 1991. 
A freqüência de uma transação está relacionada à repetição de uma mesma espécie de transação. Desta forma, quanto maior a freqüência, maior a possibilidade de diluir os custos de adoção de um mecanismo complexo por várias transações e construção de reputação por parte dos agentes envolvidos na transação.

Por um lado, a reputação economiza custos de transação, contudo, por outro, pode implicar aumento dos custos de transformação decorrido do controle de qualidade. Assim, segundo Farina et al. (1997), a freqüência das transações somente trará reputação se a economia de custos de transação for superior ao aumento dos custos de transformação.

A incerteza de uma transação está relacionada à informação assimétrica e incompleta ou quando há incerteza no reconhecimento das informações importantes ao contrato, tornando-o, assim, incompleto, estando sujeito à atitude oportunista das partes envolvidas e, portanto, a custos de transação.

É importante ressaltar que a racionalidade limitada é uma característica do indivíduo, enquanto que incerteza é uma característica do ambiente, ou melhor, da transação. A incerteza torna o problema da racionalidade limitada mais evidente pelo fato de que quanto maior a incerteza, maior o número de contingências futuras, ou seja, maior o desconhecimento de elementos futuros relacionados à transação, e portanto, mais complexa é a elaboração de contratos contingentes (Farina et al., 1997).

Em relação aos custos, sua "minimização ocorre por referência à soma dos custos de produção e transação", definindo a estrutura de governança das transações (Williamson, 1989, p.33).

O Quadro 1 relaciona os pressupostos comportamentais frente às especificidades do ativo com a forma contratual redutora de custos de transação 


\begin{tabular}{|c|c|c|l|}
\hline $\begin{array}{l}\text { Pressupostos } \\
\text { Comportamentais }\end{array}$ & $\begin{array}{c}\text { Especificidade } \\
\text { Ativo }\end{array}$ & \multicolumn{1}{|c|}{ Processo de Contratação } \\
\cline { 1 - 2 } $\begin{array}{l}\text { Racionalidade } \\
\text { Limitada }\end{array}$ & Oportunismo & + & $\begin{array}{l}\text { Planejamento (capacidade de previsão } \\
\text { de todos os problemas) }\end{array}$ \\
\hline 0 & 0 & + & $\begin{array}{l}\text { Promessa (baseado na honestidade das } \\
\text { partes) }\end{array}$ \\
\hline+ & + & 0 & Mercado \\
\hline+ & + & + & Relações hierárquicas \\
\hline+ & + & + & \\
\hline
\end{tabular}

Quadro 1 - Atributos do processo de contratação

Fonte: Williamson (1989)

No caso em que as partes tenham racionalidade total, mas são oportunistas e os ativos são específicos, todos os aspectos pertinentes do contrato se esclarecem na etapa da negociação, ex-ante, assim, sugere-se o planejamento. Nesse caso, os contratos seriam completos, uma vez que os agentes seriam todos racionais e poderiam prever todas as situações ex-ante. Na situação em que os agentes não são oportunistas, mas a racionalidade é limitada e tem-se a presença de ativos específicos, a simples promessa (acordo tácito) entre as partes seria suficiente para não se aproveitarem da incompletude dos contratos, contornando a dependência bilateral entre as partes gerada pela especificidade do ativo. No caso em que há ausência de especificidade, mas há racionalidade limitada e oportunismo, é eficaz a contratação discreta via mercado, pois os ativos podem ser livremente deslocados entre suas utilizações. Na situação com racionalidade limitada, oportunismo e especificidade dos ativos, as relações hierárquicas seriam indicadas para minimizar os custos envolvidos.

Nota-se que a especificidade do ativo só tem importância na presença de racionalidade limitada e oportunismo, sendo estes os dois pilares da ECT.

Assim, com os pressupostos comportamentais e as dimensões das transações, a ECT mostra um modelo para escolha da forma organizacional eficiente a uma 
determinada transação, considerando, de acordo com Williamson (1989) a especificidade do ativo como variável-chave. O Quadro 2 mostra o alinhamento dos contratos:

\begin{tabular}{|c|c|c|c|}
\hline \multirow{2}{*}{$\begin{array}{c}\text { Especificidade dos } \\
\text { Ativos }\end{array}$} & Baixa & Média & Alta \\
\cline { 2 - 4 } & Mercado & Mercado & Mercado \\
\hline Baixa & Contrato & Contrato ou & Contrato ou \\
Média & Contratogração vertical & Contrato ou & Integração vertical \\
\hline Alta & Integração vertical \\
& & Incal & \\
\hline
\end{tabular}

Quadro 2 - Alinhamento dos contratos: especificidade dos ativos e incerteza

Fonte: Briclkey, Smith \& Zimmerman ${ }^{6}$ citado por Zylberzstajn (2004)

Em relação ao Quadro 2, segundo Zylberzstajn (2004), quando a especificidade dos ativos é baixa, a transação pode acontecer no mercado, pois não há necessidade de forte controle sobre ela. Mas, à medida que a especificidade dos ativos aumenta, o mercado passa a ser uma solução ineficiente, sendo necessário maior controle, através da integração vertical ou contratos com salvaguardas específicas.

O modelo de Integração Vertical - Forma Analítica Reduzida - mostra segundo Williamson ${ }^{7}$ citado por Zylberzstajn (2004), a sensibilidade dos custos de governança às mudanças no grau de especificidade dos ativos relacionando-os aos diferentes modos de governança.

\footnotetext{
5 "Não existe uma clara definição dos termos verticalização e integração vertical, mas utiliza-se ambos os termos como sinônimos" (correspondência eletrônica com Zylberzstajn, 30 jun. 2004).

6 BRICLKEY, J.; SMITH, C.; ZIMMERMAN, J. Managerial economics and organizational architecture. 1.ed. New York: McGraw Hill, 1997. 33p.

${ }^{7}$ Williamson, op. cit., p.8.
} 
De acordo com esse modelo, para comparar as diferentes formas organizacionais, define uma função de custo de governança para cada uma, sendo que todas apresentam como parâmetro a especificidade de ativos (variável chave) e um vetor de parâmetros de deslocamento das funções, em que este inclui a incerteza e elementos do ambiente institucional (definição e garantia dos direitos de propriedade).

As funções que representam os custos de governança das formas organizacionais de mercado são: $M(k, \theta)$ para mercado, $X(k, \theta)$ para híbrida e $H(k, \theta)$ para hierárquica; sendo que $\mathrm{k}$ é a especificidade de ativos e $\theta$ é o vetor de parâmetros de deslocamento.

De acordo com Farina et al. (1997), considerando a eficiência relativa das formas organizacionais para diferentes níveis de especificidade de ativos, surgem algumas restrições para as funções: $M(0, \theta)<X(0, \theta)<H(0, \theta)$, qualquer $\theta \in R^{n}$, sendo $\mathrm{n}=$ número de parâmetros de deslocamento. Isso ocorre porque o mercado promove adaptações mais eficientes quando as especificidades dos ativos são negligenciáveis. Assim, dada a especificidade do ativo igual a zero, o custo de governança mercado é menor que o da híbrida, que por sua vez é menor que o da hierárquica. Em resumo, para nível de especificidade nula, o mercado é sempre mais eficiente que a hierarquia e a forma híbrida.

Conforme aumenta a especificidade de ativos (k), aumenta a dependência bilateral e, portanto, a necessidade de controle. Os custos de se usar o mercado aumentam relativamente mais à medida que se aumenta a especificidade de ativos. Assim: $\partial \mathbf{M} / \partial \mathbf{k}>\partial \mathrm{X} / \partial \mathbf{k}>\partial \mathrm{H} / \partial \mathbf{k}$.

Todas derivadas são positivas, pois a especificidade de ativos cria dependência bilateral, o que aumenta o custo de governança sobre a transação, dado $\theta=$ constante.

Como pode ser visto na Figura 1, a especificidade dos ativos, eixo das abscissas, é medida pelo índice k e no eixo vertical são representados os custos das 
transações. As três curvas representam as formas de governança via mercado (M), via hierárquica $(\mathrm{H})$ e mista $(\mathrm{X})$. Em k1, o nível de especificidade é tal que os agentes são indiferentes entre escolher mercado e híbrida; em k2 os agentes são indiferentes entre híbrida e hierárquica (Farina et al., 1997).

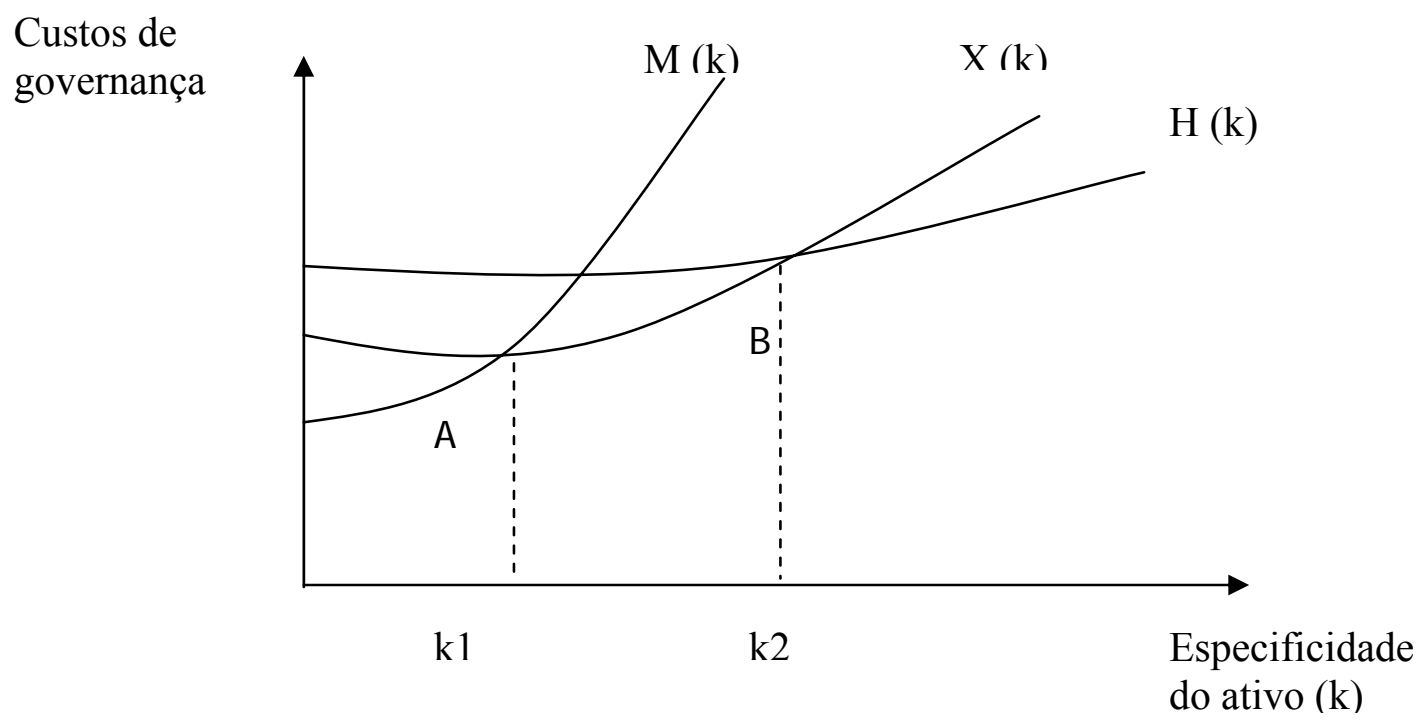

Figura 1- Formas de governança e especificidade dos ativos

Fonte: Williamson ${ }^{8}$ citado por Zylbersztajn (2004)

É possível traçar uma curva envelope que associa a especificidade de ativos aos custos de governança, que indica a forma organizacional ótima. Assim, a forma organizacional que minimiza os custos está sobre a curva envelope.

Num extremo, o ativo possui alta especificidade e está associado a perdas vultuosas caso ocorra a ruptura do contrato, sendo necessário salvaguardas contratuais, assim, é mais eficiente se as transações são conduzidas internamente à firma, prevalecendo a hierarquia (integração vertical). No outro extremo, há baixa

\footnotetext{
${ }^{8}$ Williamson, op. cit., p.8.
} 
especificidade do ativo, onde a ruptura do contrato não gera custos aos agentes, podendo reatar relações com outros agentes no mercado (mercado governa as transações). $\mathrm{O}$ caso intermediário possui forma de governança mista ou contratual, sendo os casos mais comuns de organização das empresas (Zylberzstajn, 2004).

Dessa forma, dada a especificidade $\mathrm{k}^{*}$, a forma organizacional mais eficiente será:
a) Mercado se $\mathrm{k}^{*}<\mathrm{k} 1$;
b) Híbrida se $\mathrm{k} 1<\mathrm{k}^{*}<\mathrm{k} 2$;
c) Hierarquia se $\mathrm{k}^{*}<\mathrm{k} 2$.

Se $\mathrm{k}^{*}$ estiver próximo de $\mathrm{k} 1$ ou $\mathrm{k} 2$, há indiferença entre as respectivas formas organizacionais (Farina et al., 1997).

Mudanças nos parâmetros de deslocamento afetam diferentemente cada tipo de estrutura. Esses parâmetros de deslocamento das funções são utilizados para adicionar as contribuições da corrente de ambiente institucional, representando o efeito de uma mudança institucional sobre os custos de transação obtidos pelos tipos organizacionais.

Dessa forma, o modelo Forma Analítica Reduzida apresenta uma tentativa de tratamento integrado das duas principais vertentes da NEI, que são Ambiente Institucional e Instituições de Governança (Farina et al., 1997).

\subsubsection{Limitação}

Uma limitação importante ao modelo da ECT reside na dificuldade de mensuração dos custos de transação. 
O modelo Forma Analítica Reduzida apresentada por Williamson "dribla essa limitação ao comparar a eficiência relativa das formas organizacionais, evitando a mensuração dos custos de transação em termos absolutos" (Farina et al., 1997, p.95).

Nas palavras de Zylbersztajn:

“A proposição que sustento é de que a identificação de uma base teórica útil para se entender a coordenação dos sistemas produtivos em geral e dos SAGs em particular já representa considerável avanço na literatura de agribusiness. Caso se consiga quantificar as variáveis, testes de hipóteses mais robustos poderão ser realizados..." (Zylbersztajn, 2004, p.230).

\subsubsection{Ambiente institucional}

A NEI incorpora a teoria das instituições na economia e, segundo North (1993), a incompleta informação e limitada capacidade mental de processá-la fazem com que seja necessária a imposição de restrições sobre as interações humanas a fim de estruturá-las. Assim, "a incompleta informação e limitada capacidade mental de processar a informação determinam o custo de transação reforçando a formação de instituições" (North, 1993, p.2).

Dessa forma, quando há significantes custos de transação, as instituições irão ser designadas a induzir os agentes a adquirirem informações essenciais que os conduzirão a modelos corretos. De fato, segundo North (1993):

"O Estado não pode ser considerado um ator exógeno no desenvolvimento político, e a obtenção de preços corretos somente tem a conseqüência desejada quando há um 
conjunto de direitos de propriedade e enforcement que irão conduzir a condições de mercado competitivas" (North, 1993, p.5).

O autor afirma que as instituições podem ser formais (constituição, leis e direitos de propriedade), e informais (costumes, tradições, regras de conduta). O autor distingue claramente as instituições das organizações: as primeiras são as regras do jogo da sociedade, que é composta pelas regras formais e informais; e as organizações são os jogadores, que inclui corpo político (agências reguladoras, senado, câmaras, etc), corpo social (igrejas, clubes, associações atléticas, entre outros), corpo econômico (firmas, traders, cooperativas, fazendeiros, etc.) e um corpo educacional (escolas, faculdades, entre outros).

As organizações desenvolvem-se dentro do ambiente institucional, sendo assim, limitadas e condicionadas pelas regras institucionais, porém, as instituições são da mesma forma afetadas pelas organizações.

Mudanças no ambiente institucional, devido, por exemplo, às exigências do consumidor ou à imposição de leis que obriguem a maior nível de segurança do alimento, que é o foco deste trabalho, acarretam uma mudança nas empresas no sentido de minimizarem seus custos mediante maior coordenação vertical. Dessa forma, as instituições não são neutras, pois afetam o desempenho das organizações.

A mudança institucional resulta da percepção das organizações sobre oportunidade de lucros, que depende da informação e do processamento da informação. Os agentes de mudança são os empresários, políticos ou agentes econômicos.

As mudanças das regras formais, segundo North (1994), incluem, entre outras, reformas legislativas, como a aprovação de novas leis, mudanças jurídicas resultantes de jurisprudência que altera os institutos do direito, mudanças de normas e diretivas por parte dos órgãos reguladores e mudanças de dispositivos constitucionais, os quais alteram as regras que ditam a elaboração de outras normas. 
Ressalta-se que as mudanças institucionais resultantes da alteração de restrições informais ocorrem mais gradativamente, à medida que as pessoas desenvolvem seus padrões de comportamento. Assim, a mudança das regras formais pode ser dificultada pelas restrições informais incorporadas nos costumes e tradições, os quais são muito resistentes às mudanças.

Então, para que as regras e comportamentos desejados sejam cumpridos, é necessário que haja algum mecanismo de enforcement capaz de assegurá-las e conduzilas através do tempo.Tendo como exemplo o ambiente institucional do SAG da carne bovina, pode-se considerar que mesmo que as novas regras formais (por exemplo, a regra formal da rastreabilidade) estas estariam apresentando melhores resultados se houvesse mecanismos de enforcement mais eficientes.

À medida que as organizações econômicas evoluem para tirar proveito das oportunidades de lucro, tornam-se mais eficientes e gradualmente alteram as instituições, proporcionando crescimento econômico e aumento da produtividade.

North (1993) diz que as instituições são formadas para reduzir a incerteza nas relações de troca, sendo necessárias para gerar desenvolvimento econômico. Afetam o desenvolvimento econômico pelo seu efeito sobre os custos de troca e de produção, que juntamente com a tecnologia, determinam os custos de transação e de produção, que formam os custos totais.

O modo eficiente de governança resultará, portanto, da interação entre o ambiente institucional, o comportamento dos indivíduos e das características das transações. 


\section{REVISÃO DE LITERATURA}

\subsection{Segurança alimentar (food security) e segurança do alimento (food safety)}

Segundo Spers (2003), segurança alimentar tem um enfoque quantitativo e refere-se ao abastecimento adequado de uma população, ou seja, no âmbito de saúde coletiva, enquanto que segurança do alimento possui um enfoque qualitativo, referindose à garantia do consumidor adquirir um alimento com atributos de qualidade que atendam às suas necessidades.

Nesta dissertação, trabalha-se com o conceito de segurança do alimento, realçando a importância das novas demandas ditadas pelos consumidores, resultadas principalmente da conscientização destes sobre a ecologia, importância da saúde física e do bem-estar.

A segurança do alimento pode ser garantida, por exemplo, com a implantação de programas de qualidade ao longo da cadeia produtiva da carne bovina.

\subsubsection{Segurança do alimento na União Européia}

O Livro Verde, que estabelece os princípios da legislação alimentar da UE, tem como objetivos básicos: a) garantir um nível elevado de proteção da saúde pública, da segurança e dos consumidores; b) garantir a livre circulação de mercadorias no mercado interno; basear a legislação em provas científicas e numa avaliação de riscos; c) garantir a competitividade da indústria européia e melhorar as perspectivas de exportação; d) fazer da indústria, dos produtores e dos fornecedores os principais 
responsáveis da segurança dos produtos alimentares; e) velar pela coerência, racionalidade e clareza da legislação (Europa, 2004b).

Porém, uma série de crises relacionadas à alimentação humana e animal, como por exemplo a EEB, pôs em evidência as falhas na concepção e na aplicação da regulamentação alimentar na UE, o que levou esta a promover um nível elevado de segurança do alimento, conduzindo, em 2000, a criação do Livro Branco sobre segurança do Alimento. Neste documento, a Comissão Européia propõe um conjunto de medidas que permitem organizar a segurança do alimento de forma mais coordenada e integrada.

Para restaurar a confiança das pessoas na segurança dos alimentos que consomem, a UE adotou uma estratégia global, que se assenta em três pilares (Europa, 2004b):

- Nova legislação relativa à segurança dos gêneros alimentícios e dos alimentos para animais;

- Pareceres científicos sólidos nos quais se fundamentem as decisões;

- Execução e controle da legislação comunitária.

O regulamento da legislação alimentar estabeleceu pela primeira vez, em 2002, os princípios gerais em matéria de segurança do alimento e também dos alimentos para animais,visto que a contaminação destes ocasionou os principais alertas sanitários dos últimos anos. A partir de 1 de janeiro de 2005, as empresas do setor alimentar e do setor de alimentos para animais devem assegurar a rastreabilidade dos gêneros alimentícios, dos alimentos para animais e dos respectivos ingredientes ao longo de toda cadeia alimentar.

A legislação alimentar geral é complementada por: legislação específica relativa a um conjunto de questões relacionadas com a segurança dos alimentos, tais como a utilização de pesticidas, de suplementos alimentares, corantes, antibióticos e 
hormônios na produção de alimentos; normas em matéria de higiene; procedimentos rigorosos relativos à liberação, comercialização, rotulagem e rastreabilidade das culturas e dos gêneros alimentícios que contenham organismos geneticamente modificados (OGM); integração das questões de bem-estar animal na política alimentar.

A Comissão Européia zela pela execução da legislação comunitária em relação aos gêneros alimentícios e alimentos para animais de três maneiras: verifica se a legislação comunitária foi devidamente transposta para a legislação nacional dos Estados-Membros; verifica, por meio dos relatórios enviados pelos Estados-Membros e por países terceiros, se as normas foram devidamente respeitadas; e efetua inspeções no terreno da UE e outros países (Europa, 2004a).

\subsubsection{Barreiras comerciais}

As exigências quanto à segurança e qualidade dos alimentos podem se transformar em barreiras ao livre comércio entre os países, o que poderá se constituir em grandes barreiras comerciais a serem enfrentadas pelos países que desejam se fortalecer no comércio internacional, como também para aqueles que querem ampliar sua participação no comércio mundial. Este item apresenta a definição de barreiras tarifárias e não tarifárias, que constituem obstáculos ao livre acesso a mercados.

Em relação às barreiras relativas ao comércio de bens, são apresentados os principais entraves aos três grupos de barreiras mais comuns, segundo Brasil (2001):

- Barreiras tarifárias: tarifas de importação, outras taxas e impostos, procedimentos de valorização aduaneira;

- Barreiras não tarifárias: restrições quantitativas, licenciamento de importações, procedimentos alfandegários, medidas antidumping e compensatórias;

- Barreiras técnicas: normas e regulamentos técnicos, regulamentos sanitários e fitossanitários, de vigilância animal e vegetal. 
De acordo com Brasil (2001), a partir da criação do Acordo Geral de Tarifas e Comércio (GATT) as barreiras tarifárias sofreram progressiva redução, porém, paralelamente, as barreiras não tarifárias e técnicas vêm ganhando importância como nova forma de proteção aos mercados nacionais. Assim, embora possam representar exigências legítimas de segurança e de proteção à saúde, também podem apresentar novas formas de protecionismo disfarçado.

Cabe observar que as normas e os regulamentos técnicos não são barreiras comerciais per se. Contudo, tornam-se barreiras técnicas quando assumem caráter protecionista, em que há ausência de transparência das normas ou regulamentos aplicados, pela imposição de procedimentos morosos ou dispendiosos para a avaliação de conformidade; ou em decorrência de regulamentos excessivamente rigorosos impostos pela legislação estrangeira.

Segundo Moraes (2002), nem todas restrições comercias são barreiras passíveis de negociações na Organização Mundial do Comércio (OMC) e nas negociações de livre comércio. É importante distinguir as barreiras passíveis de negociação nos acordos de comércio e na OMC daquelas impostas como restrição dos próprios consumidores, que neste caso não entram na pauta de negociação entre os países. Embora seus requisitos tornem-se um impedimento ao comércio, são restrições de mercado impostas pelos próprios consumidores e deverão ser atendidas pelos países que quiserem vender para aqueles mercados.

\subsection{Controles de qualidade}

Dentre as organizações e programas referentes à qualidade mais importantes para carne bovina, destacam-se a rastreabilidade, Boas Práticas de Fabricação (BPF), Análise de Perigos e Pontos Críticos de Controle (HACCP), Internacional Standartization Organization (ISO) e Serviço Europeu de Inspeção e Segurança do Alimento (EFSIS). 
Vinholis \& Azevedo (2000) definem rastreabilidade como:

"Um sistema de rastreabilidade, seja ele informatizado ou não, permite seguir, rastrear informações de diferentes tipos (referente ao processo, produto, pessoal e ou serviço) a jusante e ou montante de um elo de cadeia ou de um departamento interno de uma empresa. A rastreabilidade possibilita ter um histórico do produto, sendo que a complexidade do conteúdo deste histórico dependerá do objetivo a que se pretende alcançar. Este objetivo pode ser influenciado pelas estratégias adotadas e pelo ambiente externo em que a empresa está inserida" (Vinholis \& Azevedo, 2000, p.12).

O Regulamento da Comunidade Européia, CE n ${ }^{\circ}$ 1760/2000, posteriormente modificado pelo Regulamento CE $\mathrm{n}^{\circ} 1825 / 2000$, estabelece que os animais devem ser identificados individualmente através de marcadores auriculares em ambas orelhas, introduz o uso do passaporte para o deslocamento, determina a implantação de uma base de dados informatizada nacional e implanta o sistema de rotulagem da carne, com informações sobre a carne do bovino, e o local de abate do qual o animal provém.

No Brasil, o MAPA instituiu, através da Instrução Normativa $\mathrm{n}^{\circ} 1$, de 09/01/2002, o Sistema Brasileiro de Identificação de Origem Bovina e Bubalina (SISBOV), no qual a Secretaria de Defesa Agropecuária (SDA/MAPA) é responsável pela normalização, regulamentação, implementação e supervisão da execução das etapas de identificação e registro individual do rebanho brasileiro e credenciamento de entidades certificadoras, cujos dados estão inseridos no Cadastro Nacional do SISBOV.

Porém, novas regras constam de Instrução Normativa $n^{0} 77$, da Secretaria de Defesa Agropecuária (SDA), publicada dia 29 de outubro de 2004, no Diário Oficial da União (DOU), em que apenas os animais cuja carne é destinada à exportação precisam 
estar cadastrados no (SISBOV), ou seja, não obriga mais o cadastro de animais destinados aos frigoríficos não habilitados ao mercado internacional.

De acordo com Iba et al. (2003), também afirmam que:

"a rastreabilidade funciona como um complemento no gerenciamento da qualidade e quando aplicado isoladamente não traduz segurança ao produto, nem ao processo. Deve estar agregado a outros sistemas de controle de qualidade, como o HACCP e Boas Práticas" (Iba et al., 2003, p.12).

O HACCP é um processo científico que enfatiza e previne os riscos de contaminação alimentar através de medidas de controle e corretivas na indústria de alimentos. Responde a Diretiva de Higiene CEE 43/93 na UE e, no Brasil, foi implantada pela Portaria $\mathrm{n}^{\circ} 46$ de 10/02/98. O sistema HACCP tem como base a prevenção, eliminação ou redução dos perigos em todas as etapas da cadeia produtiva. Possui sete princípios básicos: 1) identificação do perigo; 2) identificação do ponto crítico; 3) estabelecimento do limite crítico; 4) monitorização; 5) ações corretivas; 6) procedimentos de verificação; 7) registros de resultados. Segundo o Instituto Euvaldo Lodi (IEL) et al. (2000), é de responsabilidade do Departamento de Inspeção de Produtos de Origem Animal (DIPOA) validar e realizar auditorias nos planos HACCP dos estabelecimentos que fazem comércio interestadual e internacional.

Em relação ao programa brasileiro de qualidade Boas Práticas de Fabricação (BPF), de acordo com Dorr (2003), entrou em vigor em 2000, e permite um controle rigoroso do ambiente onde seria produzido o produto, via procedimentos higiênicosanitários. O Manual de Boas Práticas de Fabricação deve atuar, em geral, nos itens: i) matérias-primas; ii) edificações e instalações; iii) higienização; iv) higiene pessoal; v) fabricação; vi) identificação, armazenamento e distribuição; vii) controle de pragas; viii) garantia e controle de qualidade e ix) garantia de rastreabilidade. 
Através da Instrução Normativa $\mathrm{n}^{0} 1$ de 13 de fevereiro de 2003, foi aprovado o Regulamento Técnico sobre as Condições Higiênico-Sanitárias e de Boas Práticas de Fabricação para os estabelecimentos brasileiros fabricantes e industrializadores de alimentos para animais, e também o Roteiro de Inspeção.

No que diz respeito à International Standartization Organization (ISO), uma organização sediada em Genebra (Suíça), reconhecida e aceita internacionalmente no estabelecimento de normas técnicas desenvolvidas e avaliadas no âmbito de competência de suas delegações nacionais. É uma rede dos institutos nacionais dos padrões de 146 países, sendo uma organização não-governamental.

O Instituto Brasileiro de Normas Técnicas (INMETRO) representa, no Brasil, o Comitê Brasileiro de Certificação na ISO, sendo a Associação Brasileira de Normas Técnicas (ABNT) o organismo de certificação brasileiro, credenciado pelo INMETRO, que atua na certificação de sistemas de garantia de qualidade no país. No âmbito internacional, o INMETRO é reconhecido pelo International Accreditation Fórum (IAF) como organismo credenciador, inclusive para a certificação de Sistemas de Qualidade, sendo responsável pelo credenciamento dos próprios organismos de certificação no Brasil. Conforme os critérios oficializados pelo IAF, os atos de credenciamento e de certificação são voluntários.

Deve-se, no entanto, salientar que a certificação representa um conjunto de procedimentos pelo qual uma entidade certificadora - imparcial e independente - atesta que o produto atende a requisitos pré-estabelecidos (Iba, 2003).

No que se refere ao Sistema Europeu de Inspeção e Segurança do Alimento (EFSIS), sediado no Reino Unido, é um serviço independente de inspeção de alimentos, que presta aos varejistas, fabricantes e fornecedores serviços de consultoria e certificação para as suas operações, baseado nas normas ISO e no HACCP. A posse da certificação emitida pelo EFSIS permite que a empresa venda seus produtos diretamente ao varejo da Europa (Dorr, 2003). 


\subsection{O SAG da carne bovina}

Os tópicos a seguir mostram o panorama do SAG da carne bovina, nos âmbitos mundial e brasileiro.

Cabe ressaltar que as informações estatísticas disponíveis sobre o produto carne bovina podem ser extremamente díspares entre as diversas fontes de dados, apresentando confiabilidade discutível, uma vez que há dificuldade operacional desses levantamentos devido à sonegação de informação e à existência de abate e comercialização clandestinos. Neste trabalho optou-se em utilizar dados das seguintes fontes: Departamento de Agricultura dos Estados Unidos (USDA), Instituto Brasileiro de Geografia e Estatística (IBGE), Organização Mundial das Nações Unidas para Alimentação e Agricultura (FAO).

\subsubsection{Panorama mundial do setor de carne bovina}

\subsubsection{Produção e consumo}

A Tabela 1 apresenta as estimativas de produção e de consumo per capita mundiais por tipos de carne. 
Tabela 1. Evolução da produção ${ }^{9}$ e do consumo de carnes $^{1}$

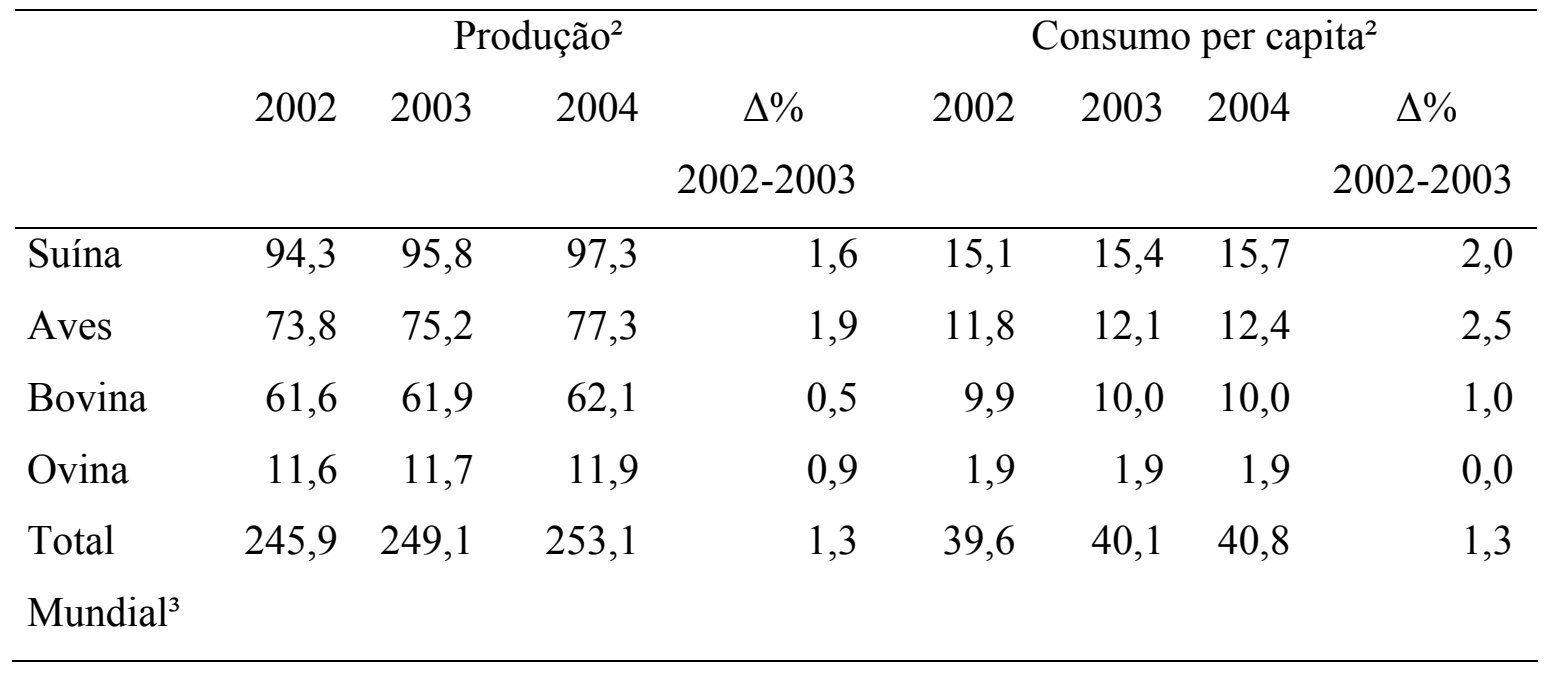

Fonte: FAO (2004)

${ }^{1}$ produção em milhões de toneladas em equivalente carcaça e consumo em kg/ano em equivalente carcaça

${ }^{2}$ os dados referentes aos anos de 2004 e 2003 são preliminares

3 inclui estas e outras carnes

Segundo os dados da Organização Mundial das Nações Unidas para Alimentação e Agricultura (FAO), Tabela 1, a produção mundial de carnes no período 2002-2003 teve um crescimento de 1,3\%, em que a carne de aves teve o maior crescimento, de 1,9\%, seguida pela suína, com um aumento de 1,6\%, ovina, com um $0,9 \%$, e a carne bovina, com apenas 0,5\%. A carne bovina representou, em 2003, aproximadamente $25 \%$ da produção mundial de todas as carnes, porém a produção de carne suína é a maior, representando $38,4 \%$ da produção mundial de carnes, seguida pela carne de aves, com 30,2\%, e a carne de ovinos, com 0,0\%. Em 2004, estima-se um aumento da produção mundial de carnes, de 1,6\% em relação à 2003.

No que diz respeito ao consumo per capita, observa-se na Tabela 3 que o consumo per capita mundial de carnes teve um crescimento de $1,3 \%$, carne bovina teve

9 Os dados referentes à produção mundial de carne bovina diferem-se entre as fontes utilizadas. 
um crescimento de apenas $1,0 \%$, enquanto que a de aves teve um crescimento maior, de $2,5 \%$, seguida pela carne suína, com $2,0 \%$, enquanto que não houve variação do consumo per capita de carne ovina. A participação da carne bovina no consumo per capita mundial total em 2003 é de $25,0 \%$, e a estimativa para 2004 é a manutenção dessa participação. A carne suína teve a maior participação em 2003 no consumo per capita mundial de carne, com $38,4 \%$, enquanto que a carne de aves tem uma participação de $30,2 \%$.

Após a crise da vaca louca em 1996, o consumo de carne bovina per capita na Europa registrou queda de 10,0\%, mas o consumo de carnes em geral registrou queda de apenas 3,0\%. Houve a substituição de carne bovina por frango, suíno e peru (Pineda, 2002).

A produção mundial de carne bovina pode ser visualizada na Tabela 2, que traz sua evolução entre 1999 e 2004. 
Tabela 2. Evolução da produção de carne bovina. (milhões toneladas métricas equivalente carcaça)

\begin{tabular}{lrrrrrrr}
\hline & 1999 & 2000 & 2001 & 2002 & $2003(*)$ & $2004(* *)$ & $\begin{array}{c}\Delta \% \\
1999- \\
\end{array}$ \\
& & & & & & & \multicolumn{1}{c}{2003} \\
\hline EUA & 12,1 & 12,3 & 12,0 & 12,4 & 12,0 & 11,6 & $-0,8$ \\
Brasil & 6,3 & 6,5 & 6,9 & 7,2 & 7,4 & 7,7 & 17,5 \\
União & 7,6 & 7,5 & 6,9 & 7,5 & 7,3 & 7,3 & $-3,9$ \\
Européia ${ }^{1}$ & & & & & & & \\
China & 5,1 & 5,3 & 5,5 & 5,8 & 6,1 & 6,5 & 19,6 \\
Argentina & 2,8 & 2,9 & 2,6 & 2,7 & 2,8 & 2,7 & 0,0 \\
México & 1,9 & 1,9 & 1,9 & 1,9 & 2,0 & 2,2 & 5,3 \\
Índia ${ }^{2}$ & 1,7 & 1,7 & 1,8 & 1,8 & 2,0 & 2,1 & 17,6 \\
Austrália & 2,0 & 2,0 & 2,0 & 2,1 & 2,0 & 2,0 & 0,0 \\
Federação & 1,9 & 1,8 & 1,8 & 1,7 & 1,7 & 1,6 & $-10,5$ \\
Russa & & & & & & & \\
Canadá & 1,2 & 1,2 & 1,3 & 1,3 & 1,1 & 1,3 & $-8,3$ \\
Ucrânia & 791 & 754 & 646 & 704 & 775 & 665 & $-2,0$ \\
Outros & 6,3 & 6,2 & 5,7 & 5,8 & 4,6 & 4,6 & $-27,0$ \\
Países & & & & & & & \\
Total & 49,6 & 50,1 & 49,0 & 51,0 & 49,7 & 50,1 & 0,2 \\
Mundial & & & & & & & \\
\hline
\end{tabular}

Fonte: Estados Unidos (2004)

${ }^{1}$ UE-15

${ }^{2}$ Inclui búfalo

(*) preliminares

$(* *)$ previsão

Conforme observado na Tabela 2, os principais produtores mundiais de carne bovina são EUA, Brasil, UE e China, que juntos detêm 66,0\% da oferta mundial. Nota-se que durante o período 1999 a 2003 o crescimento da produção mundial foi pouco expressivo, de ordem de $0,2 \%$. Contudo, este crescimento não foi uniforme entre os países. Observa-se que os EUA, que é o maior produtor, têm sua produção girando ao 
redor de 12 milhões de toneladas equivalente carcaça, sendo que no período apresentou uma redução na produção de $0,8 \%$.

Por sua vez o Brasil, segundo maior produtor mundial em 2003, apresentou um crescimento expressivo no período analisado, de aproximadamente 17,5\%. Em 2003 a produção brasileira superou a da UE, representando aproximadamente $14,9 \%$ da produção mundial de carne bovina.

Da mesma forma, China e Índia apresentaram crescimentos importantes, de 19,6\% e 17,6\% respectivamente. Por outro lado, além dos EUA, outros países/blocos tiveram decréscimo da oferta no período, dentre eles: UE (-3,9\%); Argentina (0,0\%); Federação Russa (-10,5\%); Austrália (0,0\%); Canadá (-8,3\%); Ucrânia (-2,0\%).

A Tabela 3 traz a evolução do consumo dos principais países para o período 1999-2004. Como pode se observar nesta tabela, ao longo do período 1999-2003, os EUA estabeleceram-se como os maiores consumidores de carne bovina, seguida pela UE. China e Brasil são outros importantes consumidores. Nota-se que os quatro maiores produtores são também os que detêm o maior consumo. Nesse período, houve uma diminuição do consumo mundial em 1,8\%. Em relação ao Brasil, sua participação no consumo mundial de carne bovina em 2003 é de 13,0\%, e a China teve um aumento do consumo ao longo do período analisado de $22,0 \%$. 
Tabela 3. Evolução do consumo mundial de carne bovina. (milhões toneladas métricas equivalente carcaça)

\begin{tabular}{lrrrrrrr}
\hline & 1999 & 2000 & 2001 & 2002 & $2003(*)$ & $2004(* *)$ & \multicolumn{1}{c}{$\begin{array}{c}\Delta \% \\
1999- \\
\end{array}$} \\
& & & & & & & 2003 \\
\hline EUA & 12,3 & 12,5 & 12,4 & 12,7 & 12,3 & 12,8 & 0,0 \\
União & 7,4 & 7,3 & 6,8 & 7,5 & 7,6 & 7,6 & 2,7 \\
Européia $^{1}$ & & & & & & & \\
China & 5,0 & 5,3 & 5,4 & 5,8 & 6,1 & 6,5 & 22,0 \\
Brasil & 5,9 & 6,1 & 6,2 & 6,4 & 6,3 & 6,4 & 6,8 \\
México & 2,3 & 2,3 & 2,3 & 2,4 & 2,3 & 2,4 & 0,0 \\
Federação & 2,7 & 2,3 & 2,4 & 2,4 & 2,3 & 2,3 & $-14,8$ \\
Russa & & & & & & & \\
Argentina & 2,5 & 2,5 & 2,5 & 2,4 & 2,4 & 2,2 & $-4,0$ \\
Índia ${ }^{2}$ & 1,4 & 1,3 & 1,4 & 1,4 & 1,5 & 1,6 & 7,1 \\
Japão & 1,5 & 1,6 & 1,4 & 1,3 & 1,3 & 1,1 & $-13,3$ \\
Canadá & 0,994 & 0,992 & 0,968 & 0,977 & 1,0 & 1,0 & 0,6 \\
Austrália & 0,722 & 0,645 & 0,654 & 0,704 & 0,726 & 0,672 & 0,6 \\
Outros & 6,6 & 6,4 & 5,8 & 5,9 & 4,6 & 4,4 & $-30,3$ \\
Países & & & & & & & \\
Total & 49,4 & 49,3 & 48,3 & 49,9 & 48,5 & 48,8 & $-1,8$ \\
Mundial & & & & & & & \\
\hline
\end{tabular}

Fonte: Estados Unidos (2004)

1 UE-15

${ }^{2}$ Inclui búfalo

(*) preliminares

$(* *)$ previsão

Alguns países tiveram sua demanda reduzida ao longo do período analisado, dentre eles a Federação Russa (-14,8\%), o Japão (-13,3\%), outros países $(-30,3 \%)$ e Argentina (-4,0\%). Dentre as possíveis causas para a redução da demanda pode-se citar problemas econômicos com redução da renda e problemas sanitários, como a doença da "vaca-louca". Após a nova crise de "vaca-louca" no ano 2000, de maiores magnitudes que a do ano de 1996, pois houve casos na Itália, Espanha e Alemanha, os efeitos sobre o consumo ampliaram para diversos países (Oriente Médio, Japão), além do surgimento 
de focos de febre aftosa na Inglaterra, Argentina e Rio Grande do Sul, que também tiveram efeitos negativos sobre o consumo (Pineda, 2002).

Curiosamente, a demanda de carne bovina na UE entre 1999 e 2003 não apresentou redução no período, a despeito do aparecimento de casos da doença da "vaca-louca" na Itália, Espanha e Alemanha.

Segundo análises realizadas pela FAO, continua o processo de deslocamento do consumo e da produção mundial de carne bovina, dos países desenvolvidos para os em desenvolvimento, que teriam puxado o crescimento destas variáveis em 2003 (POLÍTICAS e doenças afetam mercado mundial..., 2004a).

\subsubsection{Exportação e importação}

A Tabela 4 traz os dados sobre exportação de carne bovina, referente ao período 1999 a 2004. 
Tabela 4. Evolução da exportação de carne bovina (milhões toneladas métricas equivalente carcaça)

\begin{tabular}{|c|c|c|c|c|c|c|c|}
\hline & 1999 & 2000 & 2001 & 2002 & $2003(*)$ & $2004(* *)$ & $\begin{array}{r}\Delta \% \\
1999- \\
2003 \\
\end{array}$ \\
\hline Brasil & 0,464 & 0,492 & 0,748 & 0,881 & 1,2 & 1,4 & 158,6 \\
\hline Austrália & 1,3 & 1,3 & 1,4 & 1,4 & 1,3 & 1,3 & 0,0 \\
\hline EUA & 1,1 & 1,1 & 1 & 1,1 & 1,1 & 0,195 & 0,0 \\
\hline Canadá & 0,492 & 0,523 & 0,575 & 0,610 & 0,384 & 0,565 & $-22,0$ \\
\hline $\begin{array}{l}\text { Nova } \\
\text { Zelândia }\end{array}$ & 0,462 & 0,505 & 0,516 & 0,505 & 0,578 & 0,560 & 25,1 \\
\hline Índia ${ }^{2}$ & 0,222 & 0,365 & 0,370 & 0,416 & 0,465 & 0,520 & 109,5 \\
\hline Argentina & 0,359 & 0,357 & 0,169 & 0,348 & 0,384 & 0,420 & 7,0 \\
\hline $\begin{array}{l}\text { União } \\
\text { Européia }{ }^{1}\end{array}$ & 0,994 & 0,644 & 0,575 & 0,512 & 0,400 & 0,360 & $-59,8$ \\
\hline Uruguai & 0,189 & 0,236 & 0,145 & 0,259 & 0,314 & 0,330 & 66,1 \\
\hline Ucrânia & 0,151 & 0,157 & 0,98 & 0,146 & 0,172 & 0,140 & 13,9 \\
\hline China & 0,057 & 0,054 & 00,60 & 0,043 & 0,043 & 0,045 & $-24,6$ \\
\hline $\begin{array}{l}\text { Outros } \\
\text { Países }\end{array}$ & 0,126 & 0,128 & 0,131 & 0,188 & 0,109 & 0,095 & $-13,5$ \\
\hline $\begin{array}{l}\text { Total } \\
\text { Mundial }\end{array}$ & 5,9 & 5,9 & 5,8 & 6,4 & 6,4 & 5,9 & 8,5 \\
\hline
\end{tabular}

Fonte: Estados Unidos (2004)

1 UE-15

${ }^{2}$ Inclui búfalo

(*) preliminares

$(* *)$ previsão

Os principais exportadores de carne bovina ao longo do período 1999-2003 foram a Austrália, EUA, Brasil e Canadá.

Observa-se que as exportações de carne bovina mundial tiveram um crescimento de 8,5\%, no período 1999-2003. Em relação ao Brasil, observou-se uma tendência crescente nas exportações entre os anos 1999 e 2003, sendo que a variação no 
período foi de $158,6 \%$, e a expectativa é tornar-se o maior exportador de carne bovina em 2004. As exportações de carne bovina da Austrália nesse período em nada se alteraram, e o mesmo aconteceu para os EUA.

Em 2003, a Austrália teve uma participação de 20,3\% na exportação mundial, enquanto que o Brasil obteve uma participação de 18,7\%, e os EUA de 17,2\%.

Os ganhos no comércio internacional de carnes deverão ser supridos particularmente pelos países em desenvolvimento, à medida que os fornecimentos limitados de carnes e o aumento de preços juntos com o fortalecimento das moedas em vários países desenvolvidos contiveram sua competitividade.

A Austrália além de enfrentar um período de seca em 2003, que reduziu o seu rebanho e a sua produção de carne, e da valorização da sua moeda, dólar australiano, frente a outras moedas, tirando lhe competitividade no mercado externo, também enfrentou problemas em dois de seus principais mercados, Japão e Canadá, que devido à doença da vaca louca nesses países, apresentaram queda no consumo de carne bovina, de acordo com Yassu (2004).

O Canadá, o quarto colocado no ranking de exportações, teve o primeiro registro da doença da vaca louca em seu rebanho em maio de 2003. Já os Estados Unidos, foram afetados pela redução do embarque de cortes nobres para o Canadá, com a queda no consumo de carne bovina neste país, e com o fechamento da fronteira para a entrada do gado em pé canadense, que deixou a indústria frigorífica dos EUA com menos matéria-prima, para trabalhar, e em dezembro de 2003, constatou-se o primeiro caso da doença da vaca louca nesse país.

De acordo com BeefPoint (2003a), os exportadores da América do Sul, beneficiados pela taxa de câmbio - desvalorização de suas moedas - pelos melhores preços médios de exportação e pelas questões sanitárias nos outros fornecedores (EUA e UE), estão se recuperando e aumentando a participação da região nas exportações globais. 
Dessa forma, com a Austrália e EUA apresentando dificuldades para fornecer carne para o mercado e a demanda global se mostrando crescente, a América do Sul tem uma enorme oportunidade para se fortalecer como grande fornecedora de carne bovina no mundo. Para tanto, precisa se consolidar como uma região que possui um controle sanitário forte, eficiente, transparente e com muita credibilidade.

A Tabela 5 mostra a evolução das importações dos principais países.

Tabela 5. Evolução da importação de carne bovina (milhões toneladas métricas equivalente carcaça)

\begin{tabular}{|c|c|c|c|c|c|c|c|}
\hline & 1999 & 2000 & 2001 & 2002 & $2003\left(^{*}\right)$ & $2004(* *)$ & $\begin{array}{c}\Delta \% \\
1999- \\
2003 \\
\end{array}$ \\
\hline EUA & 1,3 & 1,4 & 1,4 & 1,5 & 1,4 & 1,5 & 7,7 \\
\hline $\begin{array}{l}\text { Federação } \\
\text { Russa }\end{array}$ & 0,838 & 0,478 & 0,650 & 0,660 & 0,590 & 0,650 & $-29,6$ \\
\hline $\begin{array}{l}\text { União } \\
\text { Européia }^{1}\end{array}$ & 0,457 & 0,450 & 0,413 & 0,518 & 0,550 & 0,560 & 20,4 \\
\hline Japão & 0,959 & 1,0 & 0,955 & 0,678 & 0,810 & 0,520 & $-15,5$ \\
\hline México & 0,358 & 0,420 & 0,046 & 0,489 & 0,370 & 0,250 & 3,4 \\
\hline Canadá & 0,254 & 0,263 & 0,299 & 0,307 & 0,274 & 0,230 & 7,9 \\
\hline $\begin{array}{l}\text { Coréia do } \\
\text { Sul }\end{array}$ & 0,242 & 0,324 & 0,246 & 0,430 & 0,444 & 0,200 & 83,5 \\
\hline Filipinas & 0,099 & 0,118 & 0,104 & 0,126 & 0,120 & 0,125 & 21,2 \\
\hline Egito & 0,218 & 0,236 & 0,136 & 0,162 & 0,100 & 0,100 & $-54,1$ \\
\hline Taiwan & 0,094 & 0,083 & 0,078 & 0,089 & 0,098 & 0,085 & 4,3 \\
\hline Brasil & 0,054 & 0,072 & 0,044 & 0,078 & 0,063 & 0,070 & 16,7 \\
\hline $\begin{array}{l}\text { Outros } \\
\text { Países }\end{array}$ & 0,318 & 0,244 & 0,216 & 0,228 & 0,201 & 0,180 & $-36,8$ \\
\hline $\begin{array}{l}\text { Total } \\
\text { Mundial }\end{array}$ & 5,2 & 5,1 & 5,0 & 5,2 & 5,0 & 4,5 & $-3,8$ \\
\hline
\end{tabular}

Fonte: Estados Unidos (2004)

${ }^{1}$ UE-15

(*) preliminares

$(* *)$ previsão 
Nota-se que as importações mundiais diminuíram em 3,8\% no período 19992003. Os principais importadores de carne bovina são EUA, Federação Russa, Japão e UE. As importações dos EUA corresponderam a 28,0\% do total mundial em 2003, tendo apresentado um crescimento de 7,7\% entre 1999-2003. A UE, maior importador de carne bovina brasileira, teve uma participação nas importações totais de 11,0\% em 2003, e ao longo do período considerado, um aumento de 20,4\%, com previsão de aumento dessa participação em 2004. No que se refere ao Brasil, não obstante tenha tido um crescimento nas importações de $16,7 \%$ no período, não é um importante importador, tendo tido uma participação de 1,3\% do total importado mundialmente em 2003.

\subsubsection{Panorama do SAG da carne bovina brasileiro}

Neste tópico, apresenta-se a caracterização do SAG da carne bovina no Brasil, em que se destacam seus principais gargalos. A Figura 2 ilustra o SAG da carne bovina, delimitado de acordo com os objetivos deste estudo, cujo foco de estudo está nas relações: do frigorífico com o fornecedor de boi (pecuária); do frigorífico com o varejo (mercado interno); e do frigorífico com o mercado europeu.

Faveret Filho \& Paula (1997) constataram que a pecuária de corte no Brasil pode ser analisada a partir de duas características básicas: a) diversidade: das raças, de sistema de criação, de condições sanitárias de abate e de formas de comercialização; b) descoordenação da cadeia produtiva: baixa estabilidade nas relações entre criadores, frigoríficos, atacadistas e varejistas, que tem como um dos efeitos a falta de rastreabilidade dos produtos, bem como a falta de qualidade do produto e informalidade.

Este fato dificulta a coordenação ao longo da cadeia, e num cenário de mudanças nos atributos de qualidade do produto, advindo das exigências dos consumidores externos, pode significar necessidade de mudanças importantes na relação entre os diversos elos produtivos. 
Os diferenciais competitivos do Brasil em relação a seus concorrentes são: fartura de terras, que possibilita ganho em escala e expansão da atividade; genética bovina melhorada e adaptada ao meio ambiente; tecnologia, que possibilita aumentar seus índices de produtividade; condições climáticas muito favoráveis à produção pecuária de baixo custo e "ecologicamente correta", ou seja, animais criados soltos, a pasto, sem hormônios ou outras substâncias proibidas e com baixo uso de insumos químicos (Franco, 2003). 


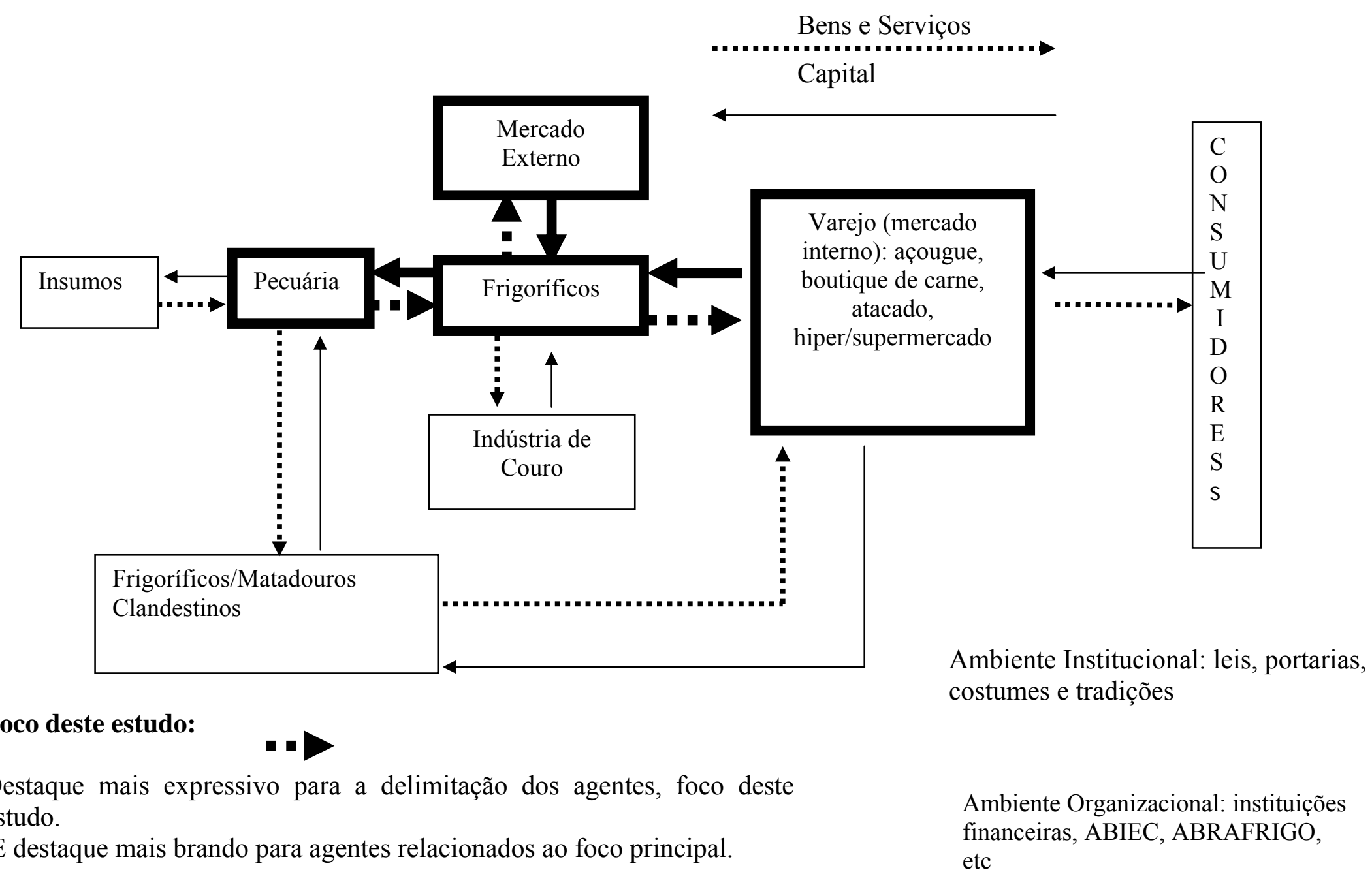

Figura 2 - O SAG da carne bovina 
Assim, um diferencial da carne do Brasil é a sua produção extensiva, ao contrário do Hemisfério Norte que possui uma produção intensiva. O Brasil é atualmente o único país com capacidade de produzir grande quantidade de carne em sistemas de produção a pasto, e considerando-se que há uma tendência internacional de valorização de sistemas de produção mais naturais (ou menos intensivos), pode-se inferir que o país tem vantagem competitiva, podendo aumentar suas exportações. Contudo, é preciso que se implante projetos para a produção de carne com qualidade assegurada, em que todas as fases de produção sejam certificadas (Cavalcanti, 2004a).

Tem-se verificado um deslocamento das unidades de abate para o Centro Oeste, devido à migração da produção primária e à modernização da bovinocultura nos estados do Brasil Central, aumentando a oferta de boi gordo.

Em relação aos frigoríficos, estima-se que existam aproximadamente 1.000 frigoríficos no Brasil, dos quais 351 possuem o aval da inspeção federal (SIF), sendo que destes, apenas 67 frigoríficos, 19,1\% do total, estão prontos a atender a demanda internacional, segundo dados da Associação Brasileira das Indústrias Exportadoras de Carne $^{10}$ (ABIEC) (citado por Oliveira Neto, 2004). É interessante observar que esses 67 frigoríficos pertencem na verdade a 17 grupos que dividem entre si $98 \%$ do faturamento bruto relativos as vendas externas. Segundo o autor, a Região Centro-Oeste do Brasil possui, atualmente, $56 \%$ das plantas frigoríficas prontas para o abate destinado à exportação.

Faveret Filho \& Paula (1997) afirmaram que a maior parte dos frigoríficos trabalhava sem marcas, e os produtores entregavam animais em situações diferenciadas (idade, sexo, gordura etc). Dessa forma, a diferenciação de produtos era limitada e fica praticamente nas mãos dos varejistas, via manipulação dos vários tipos de cortes.

10 ASSOCIAÇÃO BRASILEIRA DA INDÚSTRIA EXPORTADORA DE CARNE (ABIEC). Estatísticas. http://www.abiec.org.br (22 ago. 2004) 
A carne bovina tem desvantagem com relação a produtos substitutos (carne de frango, de suínos) pela inconstância de qualidade e padronização da matéria prima, além de ser considerada uma commodity, ou seja, um produto com baixo valor agregado e sem diferenciação (Barcellos \& Ferreira, 2003).

Quanto ao nível tecnológico, Siffert Filho \& Faveret Filho (2003), notaram que as indústrias ligadas ao segmento de exportação apresentavam elevado nível tecnológico e de acordo com padrões internacionais de competição, mas tinham alto nível de ociosidade média devido ao fechamento ou paralisação de diversas unidades.

Em contrapartida, encontram-se parte dos frigoríficos/matadouros municipais e a totalidade dos clandestinos, com baixa ou nula tecnologia de abate e processamento, e condições sanitárias insuficientes para garantir a segurança do alimento. Os frigoríficos de pequeno e médio porte vistoriados pelos sistemas de inspeção estadual possuem variações em relação ao nível tecnológico e sanitário bastante acentuadas, a depender do estado, da forma de transação com pecuaristas, dos objetivos do proprietário e dos veterinários responsáveis, entre outros fatores (Bánkuti, 2002).

Mesmo com declínio dos grandes frigoríficos líderes da década de 80 devido à elevada carga tributária e à concorrência predatória das empresas que operam legalmente com as que operam clandestinamente - o setor continuou evoluindo em termos logísticos, tecnológicos e de estrutura empresarial, incorporando setores laterais como couro e sabões, além de se especializarem no fornecimento de cortes especiais e produtos industrializados. Algumas empresas têm investido no desenvolvimento de marcas próprias, através de lojas próprias e parcerias com redes de supermercados. Os principais projetos dos frigoríficos são: aquisição de unidades industriais, diversificação de atividades e modernização de unidades existentes. Até 1998, não houve financiamentos para a construção de novas unidades (Siffert Filho \& Faveret Filho, 1998). 
No que se refere à distribuição de carne bovina no mercado interno, verificou-se que é realizada por quatro canais: supermercados, açougues, boutiques e feiras livres. Os supermercados tornaram-se a mais importante forma de venda de carne bovina no Brasil, e passaram a exigir novas formas de apresentação, qualificação e garantia da carne ofertada. Deve ser salientado que o setor de supermercados está mais concentrado que os tradicionais varejos de carne, o que lhe permite estabelecer forte poder de barganha sobre os demais segmentos do SAG (Aguiar \& Silva, 2002). Além disso, o setor supermercadista possui predomínio sobre as informações por estar mais próximo do consumidor (Souza et al., 2004).

Em se tratando do consumidor nacional, uma análise de uma recente pesquisa feita a partir da demanda de carne bovina, que verificou junto aos consumidores entrevistados que grau atribuiriam às características ligadas à qualidade da carne, sugeriu que o consumidor está muito preocupado com a segurança do alimento em que informações sobre data de validade, certificação de qualidade e registro de inspeção federal são consideradas muito importantes, acima de $90 \%$ dos consumidores de carne bovina entrevistados (Barcellos \& Ferreira, 2003).

Quanto à coordenação da cadeia produtiva, os autores Siffert Filho \& Faveret Filho (1998) observaram uma descoordenação entre os elos da cadeia, que implica na falta de rastreabilidade do produto, fazendo com que o consumidor não consiga estabelecer uma ligação entre o produto que adquire e o respectivo fornecedor. Assim, o SAG da carne bovina brasileira carece de uma organização hegemônica, dado que atualmente o fluxo de informação entre os diversos elos da cadeia ainda é muito pequeno, e esta ausência é uma das principais responsáveis pela perda de competitividade da cadeia, sendo que a transmissão de informações é realizada principalmente via preço.

Ao contrário da cadeia bovina, a cadeia avícola apresenta maior uso de relações contratuais com fornecedores, cuja integração vertical contribuiu para o desenvolvimento da indústria avícola uma vez que induziu à rápida adoção de tecnologia 
para um melhor controle da matéria-prima, economias de escala, redução de custos e diminuição de riscos na atividade, possibilitando, dessa forma, maior competitividade (Costa, 1999).

Cabe ressaltar que na cadeia de carne bovina a exigência de volume de capital é muito maior que na avicultura, além disso, o ciclo de vida do boi é mais longo, ou seja, o tempo que se leva para um bovino estar em ponto de abate é grande. É interessante, como sugestão de trabalho futuro, fazer um estudo comparativo entre os modos de governança das cadeias avícola e bovina e de seus determinantes.

Visando a organização e melhoria do relacionamento dentro da cadeia produtiva, foi constituída, em 2003, a Câmara Setorial da Carne Bovina, onde serão delineadas as futuras ações do setor via debate entre governo e representantes da cadeia. Nesse mesmo ano também houve a criação, pela indústria, da Associação Brasileira da Indústria Frigorífica (Abrafrigo), com a promessa de uma maior aproximação dos pecuaristas, defendendo maior transparência e melhoria no relacionamento com o pecuarista, bem como remunerações diferenciadas ditadas pelas classificações da carcaça e do couro (Vacas puxam crescimento da produção..., 2004b).

Iniciativas como o Sistema de Informação da Carne (SIC), sinalizam melhora no relacionamento entre os consumidores e os demais elos da cadeia. Segundo Marques (2004 apud BeefPoint, 2004b), o SIC é muito importante para mostrar a segurança do produto e seu valor bem como o papel dos agentes no processo produtivo. Apressa-se a rastreabilidade, no conceito de segurança do alimento, da fazenda até o consumidor, envolvendo todos os elos.

Não há como rastrear e certificar sem o funcionamento harmônico dos segmentos que compõem o setor pecuário, principalmente para garantir a sanidade animal. Dessa forma, o sucesso da pecuária de corte brasileira está na capacidade de harmonização da cadeia produtiva bovina (Ramos, 2004). 
Porém, portarias impostas pelo governo deverão acelerar mudanças na estrutura do setor, pois exigirão capacitação técnica e investimentos por parte dos agentes da cadeia, sendo, assim, necessário realizar um estudo mais recente e aprofundado das alterações ocorridas no setor a partir das novas exigências, que é um dos objetivos deste trabalho.

\subsubsection{Rebanho e abate}

A Tabela 6 mostra a evolução do número de cabeças do rebanho bovino brasileiro entre 1995 e 2002, por região e estado.

Verifica-se que o rebanho bovino brasileiro teve um crescimento de $15,0 \%$ no período de 1995-2002, sendo que em 2002, totalizou aproximadamente 185,35 milhões de cabeças, com todas as regiões mostrando aumentos em seus números, com exceção do Distrito Federal, que teve um decréscimo. 
Tabela 6. Evolução do rebanho bovino brasileiro por regiões e estados

\begin{tabular}{|c|c|c|c|}
\hline & 1995 & 2002 & Var.(\%) \\
\hline Região Norte & 19.183 .092 & 30.428 .813 & 58,6 \\
\hline Rondônia & 3.928 .027 & 8.039 .890 & 104,7 \\
\hline Acre & 471.434 & 1.817 .467 & 285,5 \\
\hline Amazonas & 805.804 & 894.856 & 11,1 \\
\hline Roraima & 282.049 & 423.000 & 50,0 \\
\hline Pará & 8.058 .029 & 12.190 .597 & 51,3 \\
\hline Amapá & 93.349 & 83.901 & $-10,1$ \\
\hline Tocantins & 5.544 .400 & 6.979 .102 & 25,9 \\
\hline Região Nordeste & 23.173 .936 & 23.890 .540 & 3,1 \\
\hline Maranhão & 4.162 .059 & 4.776 .278 & 14,8 \\
\hline Piauí & 2.135 .286 & 1.804 .477 & $-15,5$ \\
\hline Ceará & 2.266 .278 & 2.230 .159 & $-1,6$ \\
\hline Rio Grande do Norte & 722.058 & 839.402 & 16,3 \\
\hline Paraíba & 1.053 .737 & 951.698 & $-9,7$ \\
\hline Pernambuco & 1.362 .064 & 1.752 .722 & 28,7 \\
\hline Alagoas & 834.347 & 816.067 & $-2,2$ \\
\hline Sergipe & 796.870 & 863.447 & 8,4 \\
\hline Bahia & 9.841 .237 & 9.856 .290 & 0,2 \\
\hline Região Sudeste & 37.168 .199 & 37.923 .575 & 2,0 \\
\hline Minas Gerais & 20.146 .402 & 20.558 .937 & 2,1 \\
\hline Espírito Santo & 1.968 .311 & 1.682 .827 & $-14,5$ \\
\hline Rio de Janeiro & 1.905 .353 & 1.981 .026 & 4,0 \\
\hline São Paulo & 13.148 .133 & 13.700 .785 & 4,2 \\
\hline Região Sul & 26.641 .412 & 27.537 .047 & 3,4 \\
\hline Paraná & 9.389 .200 & 10.048 .172 & 7,0 \\
\hline Santa Catarina & 2.992 .986 & 3.117 .737 & 4,2 \\
\hline Rio Grande do Sul & 14.259 .226 & 14.371 .138 & 0,8 \\
\hline Região Centro Oeste & 55.061 .299 & 65.567 .223 & 19,1 \\
\hline Mato Grosso do Sul & 22.292 .330 & 23.168 .235 & 3,9 \\
\hline Mato Grosso & 14.153 .541 & 22.183 .695 & 56,7 \\
\hline Goiás & 18.492 .318 & 20.101 .893 & 8,7 \\
\hline Distrito Federal & 123.110 & 113.400 & $-7,9$ \\
\hline Brasil & 161.227 .938 & 185.347 .198 & 15,0 \\
\hline
\end{tabular}

Fonte: IBGE (2004) 
A região Centro-Oeste possui o maior rebanho bovino, concentrando cerca de $35,37 \%$ do rebanho nacional, em que o estado de Mato Grosso do Sul tem o maior rebanho bovino brasileiro. A região Sudeste é a segunda maior concentradora do rebanho bovino brasileiro, com uma participação de 20,46\%. A região Norte, terceira maior região produtora, foi a que teve o maior crescimento no período 1995-2002, com $58,6 \%$.

Segundo o artigo Vacas puxam o crescimento da produção... (2004b), do total de bovinos abatidos pesquisado até setembro de 2003 pelo IBGE, 8,37 milhões de cabeças eram de bois (machos com mais de 4 anos), 4,9 milhões de cabeças de Vacas (fêmeas acima de 4 anos), 2,39 milhões de cabeças de novilhos (machos e fêmeas com menos de 4 anos), e uma pequena parcela de vitelos (animais com menos de 12 meses). Se comparar com equivalente período em 2002, o volume de bois abatidos caiu 1,3\%, o de novilhos 6,5\%, mas o volume de Vacas cresceu em 48,6\%.

Os ganhos atuais da soja e da cana-de-açúcar vêm fazendo a agricultura avançar sobre as pastagens, pois superaram os ganhos obtidos com a pecuária, o que está conduzindo a um abate de matrizes elevado, pois a maioria das áreas transferidas para a agricultura é composta por fazendas de cria. Não houve repasse dos ganhos advindos da exportação, que juntamente com a baixa evolução dos preços da arroba aos produtores, levaram o pecuarista a partir para a agricultura buscando aumentar seus rendimentos (Pitombo, 2004).

Considerando os abates inspecionados acompanhados pelo IBGE, foram abatidos 4,9 milhões de Vacas, cerca de 31,5\% do total de animais, sendo que o normal, segundo o Fórum Nacional Permanente da Pecuária de Corte (FNPPC), é estar entre $20 \%$ e $25 \%$ do rebanho (Vacas puxam crescimento da produção..., 2004b). 


\subsubsection{Produção e consumo}

A Tabela 7 traz a evolução da produção e consumo brasileiros de carne bovina entre 1997-2004.

Tabela 7. Evolução da produção e consumo de carne bovina no Brasil ${ }^{1}$

\begin{tabular}{lrrrrrrrrr}
\hline & 1997 & 1998 & 1999 & 2000 & 2001 & 2002 & 2003 & $2004(*)$ & $\begin{array}{r}\Delta \% \\
1997- \\
2003\end{array}$ \\
\hline $\begin{array}{l}\text { Produção } \\
\text { Consumo }\end{array}$ & 6,1 & 6,1 & 6,3 & 6,5 & 6,9 & 7,2 & 7,4 & 7,7 & 21,3 \\
$\begin{array}{l}\text { Excedente de } \\
\text { Produção }\end{array}$ & 0,1 & 5,9 & 5,9 & 6,1 & 6,2 & 6,4 & 6,3 & 6,4 & 5,0 \\
\hline
\end{tabular}

Fonte: Estados Unidos (2004)

${ }^{1}$ milhões toneladas equivalente carcaça

(*) previsão

Observa-se que o Brasil tem apresentado uma tendência crescente na produção de carne bovina ao longo do período 1997-2003, (variação de 21,3\%), com uma taxa média anual de crescimento de 3,4\%. Em se tratando do consumo, aumentou em 2003 cerca de 5,0\% em comparação ao ano de 1997, com uma taxa média anual de crescimento de 0,8\%. Em 2003, o consumo diminuiu em 1,6\% em relação a 2002. A previsão para 2004 é o aumento tanto do consumo quanto da produção. Nota-se ao longo do tempo a existência de excedentes, que apresentaram tendência de crescimento no período analisado.

Numa entrevista, Nogueira, que preside o FNPPC, diz que o consumo interno está estagnado pela falta de poder aquisitivo da população e pela má distribuição de renda. Os dados estimados pela entidade mostraram um consumo per capita de 35,5 $\mathrm{Kg}$ em equivalente carcaça em 2003, contra 35,8\% Kg em equivalente carcaça em 2002 (Vacas puxam crescimento da produção..., 2004b). 


\subsubsection{Exportação e importação}

Atualmente, o Brasil fornece carne para 104 países, quando em 2002 exportava para 80 países, e os frigoríficos associados à ABIEC representam $96 \%$ das exportações brasileiras de carne bovina (Moraes, 2004 apud BeefPoint, 2004c).

Segundo Yassu (2004), o avanço da exportação se deve aos ganhos da pecuária em melhoramento genético, ganhos de produtividade, redução da idade ao abate e também ao reconhecimento do status sanitário brasileiro por muitos países.

A Tabela 8 traz a evolução das exportações e importações brasileiras de carne bovina entre 1997-2004.

Tabela 8. Evolução da exportação e importação de carne bovina brasileira ${ }^{1}$

\begin{tabular}{|c|c|c|c|c|c|c|c|c|c|}
\hline & 1997 & 1998 & 1999 & 2000 & 2001 & 2002 & 2003 & $2004(*)$ & $\begin{array}{c}\Delta \% \\
1997- \\
2003\end{array}$ \\
\hline $\mathrm{Ex}_{1}$ & 232 & 306 & 0,464 & 492 & 0,748 & 0,881 & 1,2 & 1,4 & 417,2 \\
\hline Importação & 0,145 & 0,102 & 0,054 & 0,072 & 0,044 & 0,078 & 0,063 & 0,070 & $-56,6$ \\
\hline Saldo & 0,087 & 0,204 & 0,410 & 0,420 & 0,704 & 0,803 & 1,1 & 1,3 & 1206,9 \\
\hline
\end{tabular}

Fonte: Estados Unidos (2004)

${ }^{1}$ milhões toneladas equivalente carcaça

(*) previsão

Em relação à exportação, observa-se que o Brasil teve um crescimento da quantidade exportada, ao longo do período 1997-2003, de 417,2\%, com uma taxa de crescimento média anual de 31,0\%. Em 2003, as exportações aumentaram em 36,2\% sobre 2002, e a estimativa é tornar-se o maior exportador mundial de carne bovina em 2004. No que se refere às importações, no período 1997-2003, nota-se que as mesmas diminuíram em 56,6\%, com uma taxa de crescimento anual negativa de 13,0\%. Em 
2003, as importações diminuíram em 19,2\% sobre 2002. A previsão para 2004 é o aumento das importações. Verifica-se também a evolução crescente do saldo das exportações brasileiras.

A Tabela 9 traz a evolução das exportações brasileiras de carne bovina por tipo de produto (in natura e industrializada). Observa-se nesta tabela que a carne bovina in natura teve um crescimento de $667,1 \%$ no período $1998-2003$, enquanto que a carne industrializada obteve um crescimento de 67,0\%. Nota-se se que a partir de 2001, a quantidade exportada de carne in natura superou a quantidade exportada de carne industrializada. O volume exportado aumentou $235,1 \%$ no período, enquanto que a receita total aumentou em $155,6 \%$.

Tabela 9. Evolução das exportações brasileiras de carne bovina ${ }^{1}$ (em peso e receita)

\begin{tabular}{lrrrrrrr}
\hline & 1998 & 1999 & 2000 & 2001 & 2002 & 2003 & $\begin{array}{r}\Delta \% \\
1998- \\
\end{array}$ \\
& & & & & & & 2003 \\
\hline In natura & 105,1 & 196,0 & 245,3 & 478,8 & 559,4 & 806,2 & 667,1 \\
Industrializada $^{\text {Total-peso }}$ & 270,1 & 352,2 & 336,2 & 336,8 & 401,2 & 451,0 & 67,0 \\
Total-receita & 375,2 & 538,1 & 581,5 & 815,6 & 960,6 & 1257,2 & 235,1 \\
(US\$) & 590,7 & 761,3 & 792,5 & 1013,7 & 1086,5 & 1509,7 & 155,6 \\
\hline
\end{tabular}

Fonte: Brasil (2004c)

1 volumes expressos em mil toneladas equivalência-carcaça, receita em milhões de dólares

Em se tratando do preço, além de aumentar o volume exportado, a cadeia de carne bovina conseguiu em 2003 um preço melhor em dólar, e graças à maior valorização do produto brasileiro, a receita total aumentou 38,9\% sobre 2002 - de US\$ 1,086 bilhão para US\$ 1,509 bilhão - bem mais que o crescimento em volume, que foi

${ }^{11}$ É interessante ressaltar que os valores dos saldos das exportações e importações da Tabela 8 se diferem do total-peso da Tabela 9 devido ao uso de fontes de dados diferentes. 
de $30,8 \%$. Na média do ano, a carne bovina in natura brasileira teve um preço médio de 3,2\% maior que em 2002 - passou de US\$ 1.084 para 1.862 a tonelada líquida - e a industrializada 1,9\% - de US\$1.933 para US\$1.969 a tonelada líquida (Yassu, 2004).

De acordo Yassu (2004), praticamente todos os países que já compravam carne bovina brasileira ampliaram o volume em 2003, principalmente de carne in natura, cujos embarques cresceram 44,1\% em volume sobre 2002, apesar da carne bovina in natura continuar fora dos principais mercados, como do Nafta (mercado comum que reúne México, Canadá e Estados Unidos) e da Ásia (Japão e Coréia do Sul), sendo a Europa o único grande mercado que o país atende.

A Tabela 10 mostra a evolução das exportações de carne bovina brasileira por destino e tipo, entre 1995 e 2003. 
Tabela 10.Evolução da exportação de carne bovina pelo Brasil por destino e tipo de produto (em mil toneladas métricas)

\begin{tabular}{|c|c|c|c|c|c|c|c|c|c|}
\hline \multicolumn{10}{|c|}{ Fresca } \\
\hline DESTINO & 1995 & 1996 & 1997 & 1998 & 1999 & 2000 & 2001 & 2002 & 2003 \\
\hline Argentina & 0 & 0 & 0 & 0,016 & 0,021 & 0,030 & 0,419 & 0,419 & 0 \\
\hline Chile & 0 & 0,022 & 0,520 & 0,661 & 10,1 & 18,5 & 40,2 & 55,7 & 76,4 \\
\hline EU & 5,3 & 5,6 & 6,7 & 7,5 & 16,9 & 24,0 & 37,5 & 41,3 & 57,1 \\
\hline Líbano & 0 & 0 & 0 & 206 & 2,3 & 3,6 & 2,6 & 4,6 & 7,8 \\
\hline Arábia & 0 & 0 & 0 & 0 & 0 & 0,103 & 0,440 & 0,592 & 1,6 \\
\hline \multicolumn{10}{|l|}{ Saudita } \\
\hline Suíça & 1,0 & 0,813 & 0,750 & 1,1 & 1,4 & 2,3 & 1,8 & 1,3 & 2,2 \\
\hline Emirados & 0 & 0 & 0 & 0 & 0 & 0,103 & 0,440 & 0,592 & 1,6 \\
\hline \multicolumn{10}{|l|}{ Árabes } \\
\hline EUA & 0 & 0 & 0 & 0 & 0 & 0 & 29 & 35 & 0 \\
\hline Outros & 0,027 & 0,010 & 0,016 & 1,4 & 0,369 & 0,302 & 0,694 & 1,9 & 4,1 \\
\hline \multicolumn{10}{|c|}{ Fresca } \\
\hline DESTINO & 1995 & 1996 & 1997 & 1998 & 1999 & 2000 & 2001 & 2002 & 2003 \\
\hline Total & 6,4 & 6,5 & 7,9 & 10,9 & 31,1 & 48,8 & 85,1 & 109,0 & 154,7 \\
\hline \multicolumn{10}{|c|}{ Congelada } \\
\hline DESTINO & 1995 & 1996 & 1997 & 1998 & 1999 & 2000 & 2001 & 2002 & 2003 \\
\hline Argentina & 0 & 0 & 0,022 & 0,112 & 0,268 & 0,134 & 0,388 & 0 & 0 \\
\hline Angola & 0,025 & 0,075 & 0,072 & 0,443 & 0,303 & 0,862 & 1,7 & 2,6 & 2,9 \\
\hline Bahrain & 0 & 0 & 0 & 0 & 0,208 & 0,175 & 0,492 & 0,296 & 0,447 \\
\hline Bulgária & 0 & 0,027 & 0 & 0 & 0 & 2,0 & 9,9 & 3,0 & 8,5 \\
\hline Chile & 0 & 0 & 0,370 & 1,7 & 8,8 & 13,1 & 16,4 & 20,2 & 19,0 \\
\hline China & 0 & 0 & 0,014 & 0 & 0,015 & 0,373 & 1,2 & 0,244 & 0,722 \\
\hline Egito & 0 & 0 & 0,946 & 2,1 & 0,277 & 2,4 & 49,6 & 47,2 & 76,2 \\
\hline UE & 23,3 & 31,8 & 33,5 & 45,6 & 72,4 & 76,4 & 77,7 & 84,4 & 94,3 \\
\hline Hong Kong & 4,2 & 2,6 & 2,6 & 3,3 & 12,7 & 11,2 & 13,5 & 14,0 & 18,9 \\
\hline Irã & 0 & 0 & 0 & 4,0 & 5,2 & 1,6 & 27,2 & 8,4 & 35,6 \\
\hline Israel & 0,991 & 1,7 & 4,1 & 7,1 & 5,7 & 12,4 & 34,4 & 19,1 & 19,1 \\
\hline Kuwait & 0 & 0 & 0 & 0 & 0,058 & 0,039 & 1,5 & 2,4 & 3,5 \\
\hline Líbano & 0,028 & 0,042 & 0,053 & 0,307 & 0,589 & 0,743 & 0,366 & 0,875 & 0,675 \\
\hline Países & 0,082 & 0,250 & 0,311 & 0,926 & 1,3 & 1,4 & 1,6 & 0,830 & 0,656 \\
\hline \multicolumn{10}{|l|}{ Baixos } \\
\hline Peru & 0 & 0,025 & 0,146 & 0,466 & 0,733 & 0,808 & 0,811 & 0,217 & 0,332 \\
\hline Filipinas & 0 & 0 & 0 & 0 & 0,025 & 0,990 & 6,8 & 17,0 & 21,7 \\
\hline Rússia & 0 & 0 & 0 & 0 & 0 & 0 & 2,0 & 39,0 & 83,5 \\
\hline Arábia & 0,100 & 0,912 & 0 & 0,075 & 1,9 & 2,3 & 24,7 & 40,7 & 39,5 \\
\hline \multicolumn{10}{|l|}{ Saudita } \\
\hline Cingapura & 1,5 & 1,6 & 1,5 & 1,7 & 6,2 & 6,3 & 7,3 & 9,8 & 11,1 \\
\hline Suíça & 0,730 & 0,366 & 0,454 & 1,9 & 2,1 & 3,1 & 1,5 & 1,6 & 3,4 \\
\hline Emirados & 0 & 0 & 0 & 0 & 0,270 & 0,576 & 1,7 & 2,8 & 3,9 \\
\hline \multicolumn{10}{|l|}{ Árabes } \\
\hline EUA & 0,014 & 0,027 & 0,030 & 0 & 0,016 & 0,023 & 0,087 & 0,081 & 0,066 \\
\hline
\end{tabular}


Tabela 10.Evolução da exportação de carne bovina pelo Brasil por destino e tipo de produto (em mil toneladas métricas)

\begin{tabular}{|c|c|c|c|c|c|c|c|c|c|}
\hline Venezuela & 0 & 0 & 0 & 0 & 0 & 0 & 0,917 & 1,8 & 0,300 \\
\hline Outros & 0,154 & 0,713 & 0,450 & 0,236 & 0,648 & 2,9 & 1,5 & 4,7 & 21,2 \\
\hline Total & 31,1 & 40,2 & 44,5 & 70,0 & 119,7 & 139,8 & 283,1 & 321,3 & 465,4 \\
\hline \multicolumn{10}{|c|}{ Processada } \\
\hline DESTINO & 1995 & 1996 & 1997 & 1998 & 1999 & 2000 & 2001 & 2002 & 2003 \\
\hline Angola & 0,109 & 0,319 & 0,312 & 0,663 & 1,4 & 1,5 & 1,9 & 4,3 & 5,7 \\
\hline Bahamas & 0,443 & 0,528 & 0,370 & 0,318 & 0,676 & 0,686 & 0,584 & 0,479 & 0,622 \\
\hline Barbados & 0,484 & 0,433 & 0,514 & 0,636 & 0,584 & 0,432 & 0,492 & 0,549 & 0,575 \\
\hline Canadá & 1,1 & 1,9 & 2,6 & 1,5 & 3,0 & 2,9 & 1,2 & 2,4 & 4,2 \\
\hline Egito & 2,4 & 1,3 & 0,411 & 1,8 & 923,0 & 1,4 & 1,4 & 2,0 & 1,3 \\
\hline UE & 60,1 & 49,4 & 47,8 & 54,2 & 67,1 & 64,0 & 66,4 & 72,7 & 74,9 \\
\hline Israel & 0,134 & 0,085 & 0,085 & 0,187 & 0,152 & 165 & 0,516 & 0,253 & 0,608 \\
\hline Jamaica & 2,7 & 1,8 & 3,3 & 3,6 & 4,2 & 2,9 & 2,2 & 3,5 & 3,4 \\
\hline Japão & 0,713 & 0,905 & 0,677 & 0,625 & 1,1 & 1,4 & 1,1 & 0,758 & 0,840 \\
\hline Jordânia & 0,518 & 0,383 & 0,705 & 0,522 & 0,851 & 0,906 & 0,871 & 1,4 & 2,8 \\
\hline Kuwait & 0 & 0 & 0,015 & 0,057 & 0,005 & 0,098 & 0,270 & 0,346 & 0,472 \\
\hline Líbano & 0,308 & 0,536 & 0,335 & 0,594 & 0,305 & 0,250 & 0,281 & 0,184 & 1,1 \\
\hline Malta & 0,811 & 0,933 & 0,710 & 0,650 & 0,775 & 0,677 & 0,771 & 0,811 & 0,704 \\
\hline \multicolumn{10}{|c|}{ Processada } \\
\hline DESTINO & 1995 & 1996 & 1997 & 1998 & 1999 & 2000 & 2001 & 2002 & 2003 \\
\hline Paraguai & 0,559 & 0,243 & 0,169 & 0,330 & 0,305 & 0,484 & 0,264 & 0,164 & 0,148 \\
\hline Filipinas & 3,0 & 2,2 & 1,4 & 633 & 717 & 902 & 346 & 950 & 1,1 \\
\hline Arábia & 0,987 & 0,941 & 0,521 & 1,2 & 1,0 & 0,794 & 0,391 & 1,3 & 1,3 \\
\hline Saudita & & & & & & & & & \\
\hline $\begin{array}{l}\text { Trindade e } \\
\text { Tobago }\end{array}$ & 0,582 & 0,738 & 0,486 & 1,2 & 1,0 & 0,785 & 1,3 & 1,2 & 1,3 \\
\hline $\begin{array}{l}\text { Emirados } \\
\text { Árabes }\end{array}$ & 0,228 & 0,221 & 0,185 & 0,179 & 0,273 & 0,297 & 0,568 & 725 & 1,2 \\
\hline EUA & 17,2 & 22,3 & 24,7 & 25,6 & 26,2 & 25,9 & 26,2 & 46,3 & 48,8 \\
\hline Outros & 5,4 & 3,0 & 2,7 & 12,1 & 28,9 & 18,5 & 18,6 & 7,5 & 13,2 \\
\hline Total & 97,8 & 88,1 & 88,0 & 106,8 & 139,4 & 125,0 & 125,9 & 147,8 & 164,2 \\
\hline $\begin{array}{l}\text { Grande } \\
\text { Total }\end{array}$ & 135,3 & 134,7 & 140,4 & 187,6 & 290,2 & 313,6 & 494,2 & 578,0 & 784,4 \\
\hline
\end{tabular}

Fonte: Estados Unidos (2004)

Nota-se na Tabela 10 que a quantidade total de carne bovina brasileira aumentou em 479,9\% no período 1995-2003, em que a carne do tipo fresca aumentou em $2326,0 \%$, a carne do tipo congelada em $1395,0 \%$ e a do tipo processada em $68,0 \%$. 
Em 2003, a carne do tipo congelada teve uma participação de $60,0 \%$ do total de carne exportada, a do tipo processada de $21,0 \%$ e a do tipo fresca de 19,7\%. Observa-se que a carne do tipo congelada é a mais exportada a partir de 2000, superando a do tipo processada.

Os dados da Tabela 10 mostram que a UE é o maior mercado importador da carne bovina brasileira, sendo que, em 2003, importou mais carne do tipo congelada, $20,3 \%$ do total deste tipo, seguidas pela do tipo processada com $45,6 \%$, e fresca com $36,9 \%$.

Segundo Miranda \& Motta (2001), a maioria da carne bovina industrializada exportada é sob a forma de corned beef (carne enlatada), sendo um produto típico de exportação, não tendo mercado interno para o mesmo, sendo a UE o principal destino dessas exportações. Quanto à carne in natura, as exportações de cortes especiais são as que têm maior participação em receita e em volume, sendo a UE o maior mercado importador.

Cabe destacar também que o Brasil exporta para o mercado europeu dentro da Cota Hilton, de atualmente 5mil toneladas, cortes da parte nobre do boi gordo, composto pelo traseiro.

Ainda com relação à Tabela 10, o Chile ficou em segundo lugar em volume total exportado do Brasil, e em receita gerada, além de manter a liderança na compra de carne in natura, sendo que só compra este tipo de carne do Brasil (Yassu, 2004).

Outros países que também aumentaram as importações de carne bovina brasileira foram o Irã, com um aumento de 425,0\%, a Rússia, e o Egito, cujas importações aumentaram em $61,0 \%$.

Como ressaltado, o ano de 2004 começou com um novo fato favorável às exportações brasileiras: registro da doença da vaca louca em dezembro de 2003 nos EUA, primeiro caso dessa doença neste país. Assim, com o Canadá e os EUA 
temporariamente fora do mercado, a cadeia de carne bovina brasileira pode se beneficiar com o aumento das vendas nos países que já compram do Brasil bem como conquistar uma parcela de outros mercados, como do Japão, da Coréia do Sul e do Nafta, que não compram carne in natura de países aftósicos e nem dos que, mesmo sem foco, vacinam seu gado, como é o caso do Brasil. Além disso, o avanço da gripe do frango pode ajudar indiretamente a abrir o mercado de carne bovina brasileira na Ásia.

O governo brasileiro tem grande expectativa nos mercados da China e nos países do Oriente Médio, que vêm aumentando gradativamente suas compras, e estes mercados são promissores pelo tamanho e por apresentar taxa de crescimento de consumo de carne expressiva (Yassu, 2004).

A Tabela 11 traz a evolução da importação de carne bovina pelo Brasil, entre 1995 e 2003. 
Tabela 11. Evolução da importação de carne bovina pelo Brasil por origem e tipo de produto, em mil toneladas métricas

\begin{tabular}{|c|c|c|c|c|c|c|c|c|c|}
\hline \multicolumn{10}{|c|}{ Fresca } \\
\hline Origem & 1995 & 1996 & 1997 & 1998 & 1999 & 2000 & 2001 & 2002 & 2003 \\
\hline Argentina & 31,6 & 61,9 & 24,0 & 5,4 & 5,0 & 4,8 & 2,7 & 6,8 & 3,3 \\
\hline Paraguai & 8,9 & 8,6 & 6,9 & 15,1 & 8,4 & 18,5 & 12,1 & 24,8 & 28,8 \\
\hline EUA & 0,0 & 5,0 & 29,0 & 185,0 & 19,0 & 0,0 & 0,0 & 0,0 & 0,0 \\
\hline Uruguai & 13,4 & 31,3 & 52,8 & 37,9 & 14,4 & 19,7 & 9,6 & 4,7 & 4,1 \\
\hline Outros & 26,0 & 15,0 & 37,0 & 0,0 & 0,0 & 0,0 & 0,0 & 0,0 & 0,0 \\
\hline Total & 53,9 & 101,8 & 83,7 & 58,7 & 27,8 & 43,0 & 24,4 & 36,3 & 36,2 \\
\hline \multicolumn{10}{|c|}{ Congelada } \\
\hline Origem & 1995 & 1996 & 1997 & 1998 & 1999 & 2000 & 2001 & 2002 & 2003 \\
\hline Argentina & 42,7 & 16,0 & 9,9 & 5,3 & 4,4 & 3,8 & 2,4 & 5,1 & 2,8 \\
\hline Paraguai & 5,1 & 3,0 & 0,961 & 0,897 & 0,641 & 1,1 & 2,3 & 2,2 & 2,6 \\
\hline EUA & 0,725 & 2,2 & 3,0 & 4,0 & 0,939 & 0,130 & 0,022 & 0,03 & 0,03 \\
\hline Uruguai & 8,2 & 8,7 & 6,5 & 3,9 & 3,2 & 2,7 & 1,9 & 11,5 & 2,8 \\
\hline Outros & 0,546 & 0,218 & 0,300 & 0,282 & 0,569 & 0,084 & 0,0 & 0,06 & 0,0 \\
\hline Total & 57,2 & 30,1 & 20,7 & 14,4 & 9,7 & 7,8 & 6,7 & 18,8 & 8,3 \\
\hline \multicolumn{10}{|c|}{ Processada } \\
\hline Origem & 1995 & 1996 & 1997 & 1998 & 1999 & 2000 & 2001 & 2002 & 2003 \\
\hline EUA & 0,001 & 0,017 & 0 & 0,009 & 0 & 0,004 & 0,010 & 0 & 0,008 \\
\hline Uruguai & 0,008 & 0,019 & 0,698 & 1,347 & 0,563 & 0,160 & 0,151 & 0,012 & 0,003 \\
\hline Outros & 0,085 & 0,623 & 0,490 & 0,166 & 0,078 & 0,004 & 0,018 & 0 & 0,019 \\
\hline Total & 0,094 & 0,659 & 1,2 & 1,5 & 0,641 & 0,168 & 0,179 & 0,012 & 0,030 \\
\hline $\begin{array}{l}\text { Grande } \\
\text { Total }\end{array}$ & 111,2 & 132,6 & 105,6 & 74,6 & 38,1 & 51,0 & 31,2 & 55,2 & 44,6 \\
\hline
\end{tabular}

Fonte: Estados Unidos (2004)

Como pode ser observado nas Tabela 11, a quantidade total de carne bovina importada pelo Brasil diminuiu em 59,9\% no período 1995-2003, em que a carne do tipo fresca diminuiu em $32,9 \%$, a carne do tipo congelada em $85,5 \%$ e a do tipo processada em 68,0\%. Em 2003, a carne do tipo congelada teve uma participação de 18,6\% do total de carne importada, a do tipo processada de $0,07 \%$ e a do tipo fresca de $81,2 \%$. Observase que a carne do tipo fresca é a mais importada. 
Ressalta que embora tenha aumentado as importações de carne bovina pelo Brasil, seu volume importado é muito pequeno em relação ao total mundial.

Os dados da Tabela 11 mostram que o Paraguai é o maior mercado exportador da carne para o Brasil, sendo que este importa mais carne do tipo fresca.

O grande fluxo de comércio do Brasil com seus parceiros no Mercosul (Argentina. Paraguai e Uruguai), se dá através de importações, sendo o Paraguai, de um lado, o maior importador da carne brasileira, em termos monetários, e de outro, o Brasil sendo o maior importador de carne bovina paraguaia, também em termos monetários.

\subsubsection{Preços e margem de lucro}

A figura 3 mostra a evolução diária do preço do boi desde janeiro de 1999 a setembro de 2004. Nota-se que o preço médio mensal do boi, deflacionado pelo IGP-DI, gordo teve uma tendência praticamente estável ao longo do período analisado.

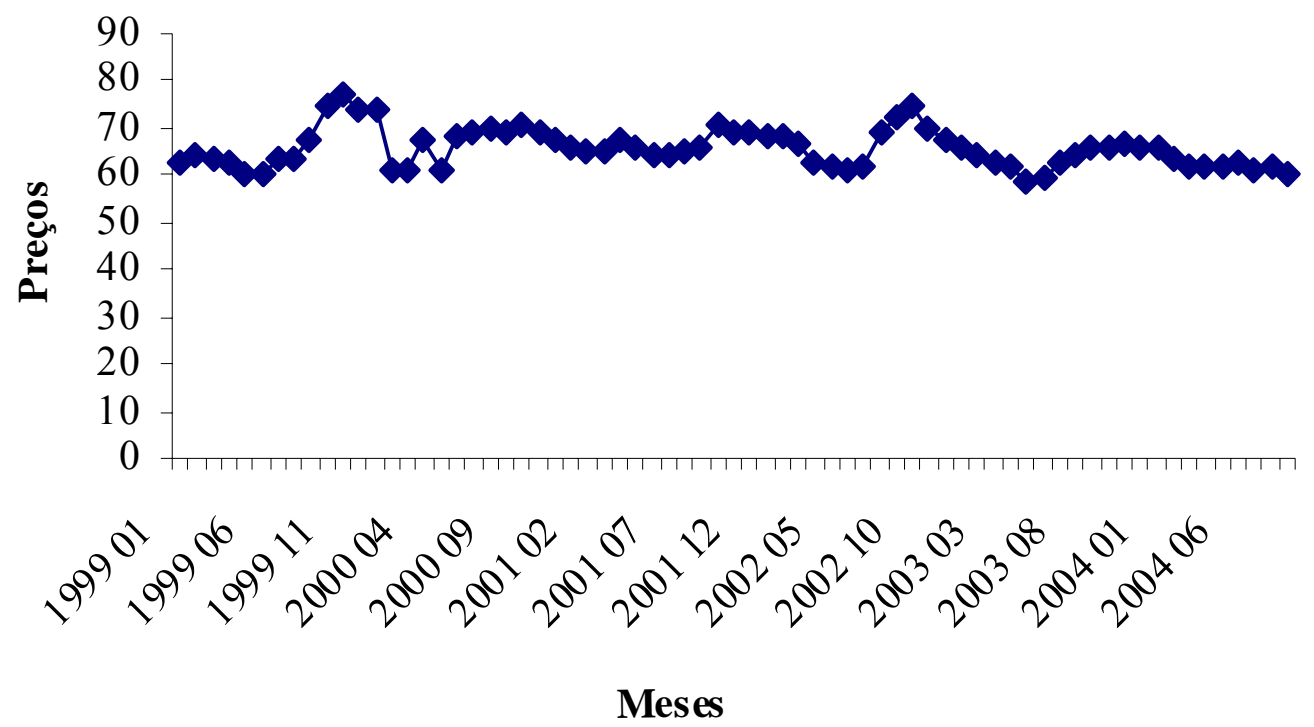

Figura 3 - Evolução dos preços à vista médios internos do boi no Brasil, em R\$ Fonte: Centro de Estudos Avançados em Economia Aplicada (CEPEA) (2004)

Nota: IGP- DI: ano base setembro/2004 (Base $=100)$ 
Em se tratando do ano de 2003, houve diminuição da margem e descapitalização dos produtores menos eficientes. Porém, aqueles que aumentaram sua produtividade têm conseguido obter melhorias de rendimento. No período de março a dezembro de 2003, segundo CEPEA/ESALQ-USP, na média, os custos operacionais subiram $4,7 \%$ em termos nominais, no entanto, o valor da arroba evoluiu apenas $1,85 \%$ em termos nominais.

Os valores de cinco importantes insumos - arame liso, calcário dolomítico, antiparasitário, vacina contra febre aftosa e sal mineral - segundo os dados do CEPEA/ESALQ-USP, no período de março até dezembro de 2003, mostrou que os custos operacionais efetivos acumulados na pecuária de corte aumentaram, na média brasileira, em 4,7\%, contra uma evolução da arroba de 1,85\%, ambos em termos nominais (Troca de insumos mostra decréscimo..., 2004d).

Em relação aos preços externos, a figura 4 mostra sua evolução de janeiro de 1999 a maio de 2004. Observa-se que os preços recebidos pelo Brasil em dólar por tonelada de carne bovina exportada tiveram uma tendência decrescente até março de 2003, voltando a crescer a partir desta data. 


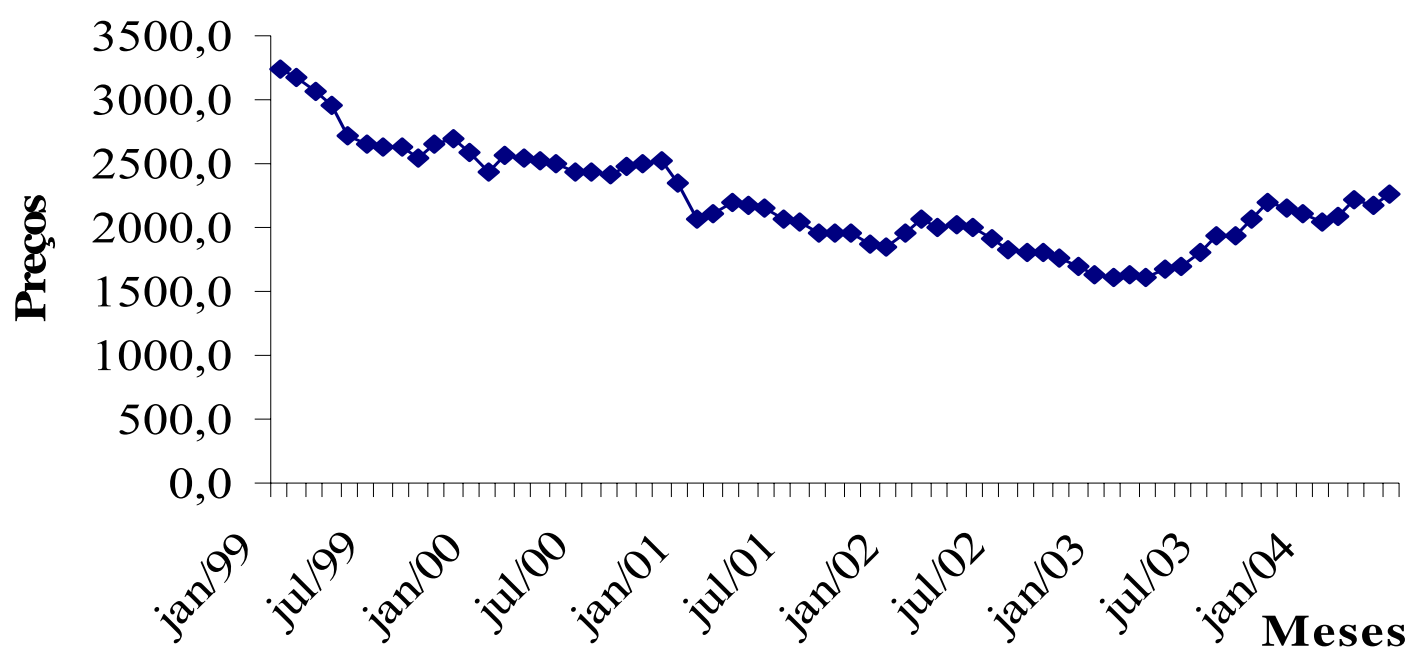

Figura 4 - Evolução do preços externos recebidos pelo Brasil na exportação de carne bovina total- US\$/T

Fonte: CEPEA (2004)

Numa entrevista, De Zen, do CEPEA, justifica este comportamento da arroba em 2003 dizendo que a economia brasileira praticamente não cresceu, o que inviabilizou o incremento da demanda interna por carne bovina, além disso, apesar das quantidades expressivas do produto enviadas ao exterior, os preços internos foram mantidos para garantir competitividade e os volumes em ascensão e avaliou que, em geral, os insumos teriam subido por um realinhamento de preços (Pecuarista de corte tem queda na renda..., 2004c).

Em relação à margem de lucro, observou-se que as margens de comercialização são pequenas, contrabalançadas pelos subprodutos ofertados. Segundo Marques, o Brasil aproveita muito pouco os subprodutos, tendo muito que crescer no aproveitamento de glândulas, ácidos, sais, gorduras, entre outros, sendo que serão mais destinados a cosméticos. Também, verifica-se que o setor é fortemente penalizado pela carga tributária no Brasil, onde esta última provocou a saída de um representativo 
número de empresas do setor, bem como instalou a ação de evasão físcal como uma forma de sobrevivência da atividade (Neves et al., 2001).

Em termos de moeda nacional, a margem apropriada pelos frigoríficos é maior que a dos pecuaristas. Ao comparar-se o ano de 2003 ao de 1998, houve um aumento de quase $600 \%$ no faturamento com as exportações em moeda nacional, mas em relação à arroba, houve apenas um aumento um pouco maior que $100 \%$.

Considerando que no período a variação do IGP-M foi positiva em 102\%, conclui-se que a arroba está aumentando exatamente o valor da inflação, o que significa que o preço relativo é o mesmo para o pecuarista (Torres Júnior, 2004).

\subsubsection{Principais desafios}

Segundo BeefPoint (2003b), um dos maiores desafios a ser enfrentado pelo SAG bovino brasileiro, é a integração da cadeia produtiva, encontrando o equilíbrio entre os interesses de seus diferentes elos.

No que se refere à coordenação vertical do SAG, Jank (1996) constatou baixos níveis de integração contratual e vertical, em que os frigoríficos compravam boi gordo no mercado spot, e verificou que no SAG da carne bovina os sistemas de fiscalização e controle sanitário eram deficientes e que havia concorrência desleal de frigoríficos que operavam no mercado informal.

Notou também a existência de forte heterogeneidade tecnológica, organizacional e gerencial, que era compensada pela autonomia de comercialização do pecuarista, em que este tinha a liberdade de escolher o momento certo de vender seu produto, recusando qualquer forma de amarração aos frigoríficos.

Em um estudo feito pelo IEL et al. (2000), notou-se que normalmente não havia nenhum contrato formal entre pecuaristas e frigoríficos, existindo apenas uma 
parceria tácita ou tradição de entrega de animais para um mesmo frigorífico, que por parte deste se baseava no conhecimento de animais de melhor qualidade, enquanto que do lado dos pecuaristas baseava-se na credibilidade da empresa. De modo geral não havia contratos formais dos varejistas com os frigoríficos, e mesmo nos programas de novilho precoce, o que prevalecia era um comprometimento de entrega para garantir regularidade na oferta de carne de precoce, também não havendo contratos, além de existir um grande número de abatedouros clandestinos em paralelo aos frigoríficos. Espera-se que com o aumento das exigências dos consumidores e conseqüente crescimento da especificidade de ativos, este arranjo organizacional tenha se alterado nos anos recentes, em direção a uma maior hierarquização das formas de governança.

Alguns dos fatores, levantados por IEL et al. (2000), que dificultavam uma maior coordenação vertical são a falta de percepção do consumidor do valor da carne de qualidade e a ineficiente inspeção sanitária, em que esta, juntamente com as regras informais (costume de comprar carne com osso, por exemplo), favoreciam a presença de unidades clandestinas.

Assim, é de fundamental importância saber quem deve coordenar o processo e como incentivá-lo, cujo aspecto será abordado no presente trabalho através da aplicação de questionários às empresas frigoríficas.

Outros desafios mencionados foram a concretização da posição de primeiro lugar em exportações de carne bovina no mundo, aumento de qualidade, redução da carga tributária, expansão dos mercados, realização de marketing da carne e real implantação da rastreabilidade como ferramenta para obter um alimento seguro.

Além disso, constatou a falta de integração entre os elos da cadeia. No SAG da carne bovina não existe união entre os produtores de boi, o que dificulta a obtenção de poder de barganha nas negociações com os outros elos, que por sua vez estão cada vez mais organizados, destacando-se as principais associações de frigoríficos, ABIEC e Abrafrigo, que estão mais profissionalizadas, permitindo e incentivando a evolução de seus associados. Também, percebe-se um avanço gerencial e tecnológico nos 
frigoríficos, que estão trabalhando cada vez mais sincronizados. Contudo, são necessárias melhorias em todos os elos para que o SAG da carne se fortaleça.

A tipificação da carcaça também foi destacada por Cavalcanti (2004b), pois sua implantação permitirá um sistema de remuneração indexada na qualidade, sendo que boas carcaças poderão ser premiadas e carcaças inferiores descontadas.

\subsection{Ambiente institucional}

Os consumidores europeus passaram a defender o bem-estar animal, a saúde animal, a saúde pública e a preservação ambiental. Essas novas demandas surgiram principalmente em função dos problemas causados pela doença da "vaca-louca" (encefalopatia espongiforme bovina ou EEB) na Europa, decorrente do consumo pelo gado de rações à base de proteína animal, que resultou na introdução de sistemas rigorosos de rastreabilidade dos produtos cárneos, tornando necessário o estabelecimento de um enfoque integrado entre os elos da cadeia de modo a recuperar a confiança dos consumidores através de padrões de rastreabilidade do produto. Diante disso, pecuaristas, frigoríficos e governo brasileiro começam a discutir formas de qualificar e certificar a carne bovina. (Faveret Filho e Paula, 1997).

O Quadro 3 discrimina os principais eventos que podem ter alterado o ambiente institucional em países, principalmente na UE e no Brasil, que são os focos de estudo deste trabalho. Nota-se que os eventos relacionados à doenças da febre aftosa e da vaca-louca são os principais responsáveis por mudanças no ambiente institucional nos países, pois tais eventos relacionam-se, sobretudo, à segurança sanitária dos alimentos, que por sua vez, têm reflexos imediatos na área econômica. 


\begin{tabular}{|c|c|}
\hline Ano & Descrição do Evento \\
\hline 1986 & $\begin{array}{l}\text { No mês de novembro foi confirmado o primeiro caso de Encefalopatia } \\
\text { Espongiforme Bovina (EEB) na Grã-Bretanha. }\end{array}$ \\
\hline 1989 & UE baniu três hormônios naturais e dois sintéticos na produção de carne. \\
\hline 1991 & $\begin{array}{l}\text { Adoção de um programa de erradicação da febre aftosa pelo Brasil, com metas } \\
\text { para os circuitos pecuários. }\end{array}$ \\
\hline 1993 & $\begin{array}{l}\text { - Em janeiro foi constituído o mercado único da Comunidade Européia, com a } \\
\text { implementação do Single European Act, instituindo o livre movimento de bens, } \\
\text { serviços, capital e trabalho no território abrangido } \\
\text { - Criação do NAFTA } \\
\text { - Uruguai declarou-se livre de febre aftosa com vacinação. }\end{array}$ \\
\hline 1994 & $\begin{array}{l}\text { - No mês de julho houve a implementação do Plano Real no Brasil } \\
\text { - Em setembro teve-se a notícia de que mais de } 137 \text { mil cabeças morreram na } \\
\text { Grã-Bretanha de EEB. }\end{array}$ \\
\hline 1995 & $\begin{array}{l}\text { Em janeiro entra em vigor o Acordo de Medidas Sanitárias e Fitossanitárias } \\
\text { (SPS). }\end{array}$ \\
\hline 1996 & $\begin{array}{l}\text { - Descoberta de uma relação possível entre a EEB e sua variante humana, a } \\
\text { doença Creutzfeldt (CJD) (Europa, 2004a) } \\
\text { - Estabelecimento do HACCP nos EUA }\end{array}$ \\
\hline 1997 & $\begin{array}{l}\text { - Desde a descoberta da relação entre as doenças EEB e CJD, a partir de } 1997 \text { a } \\
\text { Comissão Européia comprometeu-se a reformular completamente a legislação em } \\
\text { matéria de segurança dos alimentos (Europa, 2004a) } \\
\text { - OIE declara Argentina e Paraguai livres de febre aftosa } \\
\text { - Comunidade Européia propôs proibir todos os produtos que contêm materiais de } \\
\text { risco específico (cérebros, olhos, coluna vertebral etc) de terceiros países } \\
\text { infectados com EEB. }\end{array}$ \\
\hline 1998 & $\begin{array}{l}\text { - Em março foram descobertos focos de febre aftosa em Porto Murtinho -MS } \\
\text { - Em maio ocorreu a declaração do RS e SC como estados livres de aftosa com } \\
\text { vacinação. } \\
\text { - Em maio a OIE revisou o código de saúde Animal, passando a adotar uma nova } \\
\text { definição de país livre de EEB } \\
\text { - No mês de outubro detectou-se foco de febre aftosa em Naviraí -MS. }\end{array}$ \\
\hline 1999 & $\begin{array}{l}\text { Em dezembro o governo brasileiro publica portaria declarando o circuito pecuário } \\
\text { Centro-Oeste livre de febre aftosa com vacinação. }\end{array}$ \\
\hline 2000 & $\begin{array}{l}\text { - No mês de maio a Argentina, RS e SC são declarados livres de aftosa sem } \\
\text { vacinação; circuito Centro -Oeste declarado livre com vacinação pela OIE } \\
\text { - Em julho rebanhos foram sacrificados na França } \\
\text { - Em agosto detectou-se foco de aftosa em Jóia - RS } \\
\text { - Em setembro detectou-se foco de aftosa na Argentina } \\
\text { - No mês de novembro a Espanha constatou o primeiro caso de vaca } \\
\text { contaminada. } \\
\text { - A UE estabelece um sistema de identificação animal e registro de bovinos, } \\
\text { sistemas de rotulagem obrigatória e um sistema de rotulagem facultativa para a } \\
\text { carne bovina, que se aplicam tanto aos países membros da Comunidade Européia } \\
\text { (CE) quanto aos seus fornecedores de produtos cárneos. }\end{array}$ \\
\hline
\end{tabular}

Quadro 3 - Quadro sinóptico de eventos que podem ter provocado mudanças no ambiente institucional 


\begin{tabular}{|l|l|}
\hline Ano & \multicolumn{1}{c|}{ Descrição do Evento } \\
\hline 2001 & $\begin{array}{l}\text { - Em janeiro houve a proibição de utilizar as "farinhas animais" na alimentação } \\
\text { animal em todo o território da UE } \\
\text { - Em janeiro detectou-se o primeiro caso de vaca-louca na Itália } \\
\end{array}$ \\
$\begin{array}{l}\text { - Em maio constatou-se foco de febre aftosa em Santana do Livramento -RS } \\
\text { - Em setembro detectou-se o primeiro caso de vaca-louca no Japão } \\
\text { - Febre aftosa no Reino Unido: preferiu abater milhões de animais e continuar } \\
\text { com o status de livre de aftosa sem vacinação ao invés de retroceder a status livre } \\
\text { com vacinação (Cavalcanti, 2004b) }\end{array}$ \\
\hline 2002 & $\begin{array}{l}\text { - Em janeiro o Brasil instituiu o SISBOV } \\
\text { - No final deste ano, o Paraguai perdeu o status de área livre após a ocorrência de } \\
\text { febre aftosa na província de Canindeyu. }\end{array}$ \\
\hline 2003 & $\begin{array}{l}\text { - Em maio detectou-se o primeiro caso da doença da vaca-louca no Canadá } \\
\text { - Em dezembro constatou-se o primeiro caso da doença da vaca-louca nos EUA. }\end{array}$ \\
\hline 2004 & $\begin{array}{l}\text { - Em maio detectou-se febre aftosa no Sul do Pará } \\
\text { - Constatou-se febre aftosa na Colômbia. } \\
\text {-Em setembro detectou-se febre aftosa na Amazônia }\end{array}$ \\
\hline
\end{tabular}

Quadro 3 - Quadro sinóptico de eventos que podem ter provocado mudanças no ambiente institucional

Fonte: elaborado a partir de Miranda (2001)

Segundo Pineda (2002), essas novas demandas do mercado internacional têm exigido uma mudança radical nas legislações, objetivos, ações, visando atender essas novas demandas dos mercados nacional e internacional, oferecendo produtos com certificação de origem e qualidade.

\subsubsection{Análise das mudanças no ambiente institucional da União Européia}

De acordo com o Relatório Anual de Barreiras Externas das Exportações Brasileiras em relação à UE (Brasil, 2001), a Comissão Européia é o principal órgão executivo da União, agindo com total autonomia em relação aos Estados Membros e desempenhando papel relevante na concepção e implementação da política comercial comum da UE. 
Em relação à saúde e proteção ao consumidor, a prioridade deve ser a restituição da confiança do cidadão comunitário em suas instituições, confiança essa abalada em função da doença da "vaca-louca", devido à descoberta de uma possível relação entre a EEB e a sua variante humana, a doença de Creutzfeldt-Jakob, diagnosticada pela primeira vez em 1996.

Por conseguinte, a Comissão Européia comprometeu-se, desde de 1997, a reformular completamente a legislação em matéria de segurança dos alimentos, principalmente no que se refere ao regulamento sanitário, fitossanitário e de saúde animal (Europa, 2004a). Cabe ressaltar que o ano de 1996 foi apenas um marco na exigência de novas diretivas e a reformulação das existentes na UE, o que não significa que antes deste ano não se tenha implementado diretivas a fim de proporcionar segurança dos alimentos.

No âmbito das encefalopatias espongiformes transmissíveis (EET), as autoridades européias estão preocupadas com os ingredientes de origem animal, evidenciada pela Diretiva 90/667/CEE, de 27 de novembro de 1990, que estabelece normas sanitárias para a eliminação e a transformação de resíduos animais antes de sua colocação no mercado e para prevenir a propagação de agentes patogênicos nos alimentos para animais. (Europa, 2004a).

Devido à doença da "vaca-louca", foi emitido, em 22 de maio de 2001, o Regulamento (CE) n $n^{\circ}$ 999/2001 [Jornal Oficial L 147 de 31.05.2001] do Parlamento Europeu e do Conselho, que estabelece regras para a prevenção, o controle e a erradicação de determinadas encefalopatias espongiformes transmissíveis, a fim de assegurar um elevado nível de saúde pública e de segurança dos alimentos. Este regulamento estabelece: o processo, os critérios e as categorias que permitem definir os Estados Membros e os países terceiros em relação ao seu estatuto EEB; a natureza e o tratamento das matérias de risco especificadas (MRE); o sistema de vigilância ativa; as proibições relativas à alimentação dos animais (Europa, 2004a). 
O Regulamento (CE) n ${ }^{\circ}$ 1774/2002 [Jornal Oficial L 273 de 10.10.2002] relativo aos subprodutos animais não destinados ao consumo humano, é aplicável desde maio 2003. Também estabelece regras de sanidade animal e de saúde pública relativas à recolha, ao transporte, à armazenagem, ao manuseamento, o tratamento e a eliminação de subprodutos animais.

Além disso, os Estados Membros proíbem a alimentação "de animais de criação mantidos, engordados ou criados para a produção de alimentos com proteínas animais transformadas", de acordo com o artigo $1^{\circ}$ da Decisão da Comissão 2002/2048/CE, de 27 de março de 2002. Entende-se por "proteínas animais transformadas a farinha de carne e ossos, a farinha de carne, a farinha de ossos, a farinha de sangue o plasma seco e outros produtos do sangue, as proteínas hidrolisadas, a farinha de cascos, a farinha de chifres, os subprodutos do matadouro de aves, a farinha de penas, os torresmos secos, a farinha de peixe, o fosfato bicálcio, a gelatina e quaisquer outros produtos semelhantes, incluindo misturas, os alimentos para animais, os aditivos destinados à alimentação animal e as pré-misturas para alimentos para animais contendo estes produtos", segundo a Decisão do Conselho 2000/766/CE, artigo $1^{\circ}$ (Dörr, 2003).

Em relação à Organismos Geneticamente Modificados (OGM), o regulamento (CE) $\mathrm{N}^{\mathrm{o}} 1829 / 2003$, de 22 de setembro de 2003, relativo a gêneros alimentícios e alimentos para animais geneticamente modificados, relata que só deverão ser autorizados para colocação no mercado comunitário após uma avaliação científica dos riscos que apresentam para a saúde humana e animal, em que a rotulagem desses alimentos é obrigatória, para permitir ao consumidor o direito à informação. Estes procedimentos deverão ser aplicados de forma não discriminatória aos produtos originários da Comunidade e aos produtos importados de países terceiros.

No tocante a medidas de controle da febre aftosa, a diretiva 85/511/CEE, de 18 de novembro de 1985, [Jornal Oficial L 315 de 26.11.1985], estabelece medidas comunitárias de luta contra a febre aftosa, em que a existência ou suspeita de febre 
aftosa são objetos de uma notificação obrigatória e imediata à autoridade competente (Europa, 2004b).

Em relação às importações de produtos animais, estas têm de ser originárias de estabelecimentos aprovados pela Comissão Européia (Diretiva n ${ }^{\circ}$ 92/46). O processo de aprovação exige que as autoridades dos países exportadores relacionem, para cada categoria de produto, os estabelecimentos responsáveis pela produção, assegurando que tais estabelecimentos atendem os requerimentos de saúde pública e animal da UE. Além disso, as inspeções sanitárias feitas pela UE em terceiros países incluem referência ao atendimento das exigências de bem estar animal, que não correspondem às regras da Organização Mundial do Comércio (OMC) (Brasil, 2001).

De acordo com a Diretiva 96/23/CE (Brasil, 2001), que entrou em vigor em janeiro de 1997, sobre resíduos biológicos, a importação de animais e de carne de animais que foram administrados com determinados hormônios de crescimento é proibida pela UE.

A UE, em 1997, instituiu um programa de etiquetagem da carne bovina, que na primeira fase foi voluntário (01 de abril de 1998 a 31 de agosto de 2000), sendo que a partir de 01 de setembro de 2000 passou a ser obrigatório com a publicação do Regulamento (CE) no 1760/2000 [Jornal Oficial L 204 de 11 de agosto de 2000], que revogou a regulamentação anterior. Assim, toda carne bovina comercializada na UE deverá ter obrigatoriamente etiqueta com indicação do código de rastreabilidade e dos locais de abate e de desossa. A partir de 2002 completou-se a implantação do sistema obrigatório, passando a ser necessário indicar informações referentes à fase "antemortem” (Brasil, 2001).

Em 2001, a Comissão econômica para a Comunidade Européia, da Organização das Nações Unidas (UNECE), concluiu o projeto iniciado em 1997 que teve por objetivo a criação de uma linguagem internacional para o mercado da carne bovina. Trata-se de um sistema de padronização, nomenclatura e numeração de atributos do produto, desenvolvidos por peritos das principais regiões produtoras e exportadoras 
do mundo, para facilitar o comércio internacional de carne bovina, superando, assim, as dificuldades de comunicação técnica entre compradores e vendedores. As especificações são transmitidas por meio de mensagens eletrônicas padronizadas e as embalagens são identificadas com códigos de barra que pode estar associado a rastreabilidade individual ou por lote (Pineda, 2002).

\subsubsection{Análise das mudanças no ambiente institucional no Brasil}

As mudanças nos padrões de consumo do consumidor europeu, decorrentes das exigências relativas à segurança do alimento implicaram na necessidade de aplicação de mecanismos mais efetivos de controle sanitário em toda a cadeia produtiva bovina brasileira, exigindo um maior grau de coordenação e adaptação da legislação nacional.

Em virtude das exigências dos consumidores europeus, frente a doença da vaca louca, foram estabelecidas no Brasil portarias a fim de aumentar a qualidade da carne e atender os requisitos exigidos pela UE. A seguir, comentam-se as principais portarias implementadas com esse propósito (ver anexo B).

A Portaria $n^{\circ} 304$ de 22 de abril de 1996 visa a manutenção da qualidade higiênico-sanitária das carnes obtidas nos estabelecimentos sob inspeção sanitária oficial, por meio da instalação de salas de desossa nos locais de abate, e procedimentos de embalagem, padronização de temperatura, entre outros. De maneira bem simplificada, pode-se considerar que a portaria busca a melhoria da qualidade e padronização da carne bovina. A carne deveria deixar os frigoríficos já desossada em temperatura de $7^{\circ} \mathrm{C}$, embalada, identificada (etiquetas e carimbos do serviço de inspeção) e em cortes padronizados (Bánkuti, 2002). Segundo Jank (1996), nas embalagens devem constar, entre outros, a identificação do abatedouro, os dados sobre a tipificação da carcaça, a procedência, a classificação, a qualidade e o carimbo do Serviço de Inspeção Federal (SIF). 
Em 15 de julho de 1996 foram editadas as Portarias 89 e 90, ampliando a Portaria 304, estabelecendo a prévia embalagem e identificação das carnes, e não mais a desossa obrigatória no local de abate, como a Portaria 304 previa (Bánkuti \& Azevedo, 2004a).

Segundo Bánkuti \& Azevedo (2004a), como essas medidas não inibiram os clandestinos, em 04 de Janeiro 1999 foi estabelecida a Portaria 145, que implanta definitivamente a obrigatoriedade de desossa em locais inspecionados, corte, embalagem e rotulagem com informação a respeito do peso, tipo de carne e prazo de validade. Assim os frigoríficos estão autorizados a comercializarem carnes com osso (carcaça) para outros frigoríficos e entrepostos que possuem sala de desossa aprovada e sistema de inspeção sanitário, e comercializarem carne desossada para estabelecimentos sem sala de desossa.

Essas medidas têm como objetivo a busca da qualidade da carne, através da modernização e racionalização dos sistemas, tentando diminuir os abates clandestinos, assim como aumentar o fluxo de informações ao longo da cadeia.

A Portaria $\mathrm{n}^{\mathrm{o}} 46$ de 10 de fevereiro 1998 está relacionada, conforme o texto do IEL et al. (2000), com a indústria frigorífica voltada ao comércio interestadual e/ou internacional, e orienta tais frigoríficos na implantação do HACCP. Este sistema tornará mais eficaz o Serviço de Inspeção Federal e sua implantação é imprescindível para atendimento das exigências internacionais.

Em relação ao programa de rastreabilidade, a partir da Instrução Normativa $\mathrm{n}^{\mathrm{o}}$ 01, de 09 de janeiro de 2002, o MAPA instituiu o Sistema Brasileiro de Identificação de Origem Bovina e Bubalina (SISBOV), que tem a finalidade de identificar, registrar e monitorar, individualmente, todos os bovinos e bubalinos nascidos no Brasil ou importados Certificadoras Credenciadas.

Porém, através da Instrução Normativa $\mathrm{n}^{0}$ 77, apenas os animais cuja carne é destinada à exportação precisam estar cadastrados. Segundo esta nova Instrução, os 
animais não precisam estar registrados no SISBOV para participar de leilões, feiras e exposições realizadas no território nacional, além disso, o sistema não obrigará mais o cadastro de animais destinados aos frigoríficos não habilitados ao mercado internacional. O registro deve ser feito até 40 dias antes do gado e dos búfalos serem abatidos nos frigoríficos credenciados para atender o mercado externo. Essas mudanças no Sisbov foram feitas a partir de reivindicações apresentadas ao Mapa pela cadeia produtiva da carne bovina.

Segundo Pineda (2002), a rastreabilidade está vinculada aos aspectos de segurança do alimento, sendo uma ferramenta na procura de qualidade, podendo identificar um lote de carne e associar esta carne aos animais geradores, identificar seu manejo e os proprietários, tornando estas informações em instrumentos para alavancar inovações tecnológicas e promover a integração da cadeia.

De acordo com o autor, deve-se aproveitar a implantação da rastreabilidade para incentivar a integração da cadeia produtiva e introduzir programas de qualidade e marketing que ajudem na conquista de novos mercados. Rastreabilidade é um conceito técnico necessário para garantir um alimento seguro, sendo crescente a necessidade de informar ao consumidor as características do produto, todo seu processo de produção e comercialização.

Cabe ressaltar que apesar da exigência de rastreabilidade, muitos pecuaristas ainda não a adota integralmente, ou seja, não a adota seguindo rigidamente as normas estabelecidas, o que evidencia a falta de enforcement. Apesar disso, o SISBOV representa um avanço na modernização da pecuária nacional, motivando pequenos produtores a adotarem a rastreabilidade, além de facilitar a gestão das fazendas e do fluxo de informações no setor, que forçará o diálogo entre os pecuaristas e os frigoríficos, provocando transformações estruturais importantes.

Dessa forma, é essencial pesquisar profundamente as alterações recentes na coordenação do SAG da carne bovina brasileira bem como as exigências da UE, no que diz respeito à qualidade da carne. 


\subsubsection{Clandestinidade da carne bovina no Brasil}

No mercado nacional de carne bovina nota-se a existência de empresas clandestinas atuando em paralelo com as empresas formais na comercialização do mesmo produto, havendo, assim, uma concorrência desleal na disputa pelo mercado consumidor.

A elevada carga tributária existente provocou a saída de um grande número de empresas do setor, bem como propiciou a adoção de evasão fiscal como uma forma de sobrevivência das empresas, sendo um dos fatores que provocou o desestímulo e desorganização do setor. (Neves et al., 2001).

Segundo Bánkuti \& Azevedo (2004a), até meados da década de 80, a alíquota de ICMS dos produtos agropecuários esteve entre 4,52\% e 17,8\%, dependendo do estado considerado. Contudo, em 1984, a alíquota foi unificada e fixada em $17 \%$ em todo o país, sob a alegação do aumento da economia informal. Em 1992, o Convênio ICMS n ${ }^{\circ} 83$ permitiu aos estados a redução da base de cálculo do ICMS para produtos da cesta básica. Dessa forma, alguns estados incorporaram os produtos de origem pecuária, com alíquota de 7\%. Mas, grande parte dos produtos produzidos pelo setor escapa dos impostos, via abate clandestino e/ou sonegação fiscal.

É importante também mencionar que o ICMS não é o único imposto incidente na comercialização de carnes, a este se somam o COFINS, FUNRURAL, PIS e outros.

O Quadro a seguir mostra os principais tributos da cadeia de carne bovina brasileira: 


\begin{tabular}{|l|l|l|l|l|}
\hline & $\begin{array}{c}\text { Alíquota } \\
(\mathbf{\%})\end{array}$ & Base de Cálculo & \multicolumn{1}{|c|}{$\begin{array}{c}\text { Incidência na } \\
\text { Cadeia }\end{array}$} & Características \\
\hline PIS & 0,65 & Faturamento & Todas as empresas & Cascata \\
\hline COFINS & 2,1 & Faturamento & Todas as empresas & Cascata \\
\hline CPMF & 0,38 & $\begin{array}{l}\text { Movimentação } \\
\text { Financeira }\end{array}$ & $\begin{array}{l}\text { Toda a cadeia } \\
\text { (pessoas físicas e } \\
\text { jurídicas) }\end{array}$ & Cascata \\
\hline CSLL & oito & Lucro Líquido & Todas as empresas & Cascata \\
\hline ITR & 0,03 a 20 & Valor da terra nua & Pecuária & $\begin{array}{l}\text { Depende do } \\
\text { grau de } \\
\text { utilização e } \\
\text { tamanho do } \\
\text { imóvel }\end{array}$ \\
\hline $\begin{array}{l}\text { INSS } \\
\text { (FUNRURAL) }\end{array}$ & 2,1 & Faturamento & Pecuária & $\begin{array}{l}\text { Não pode ser } \\
\text { diferido }\end{array}$ \\
\hline ICMS & 0 a 12 & Valor Agregado & Todas as empresas & $\begin{array}{l}\text { Principal objeto } \\
\text { da guerra fiscal }\end{array}$ \\
\hline
\end{tabular}

Quadro 4 - Principais atributos incidentes na cadeia de carne bovina

Fonte: IEL et al. (2000)

Além disso, há uma guerra fiscal entre os estados, levando a uma tributação diferenciada e gerando distorções na competição entre frigoríficos pela aquisição de matéria-prima (Neves et al., 2001).

De acordo com IEL et al. (2000), a fragilidade financeira das indústrias frigoríficas é devido principalmente à concorrência predatória das empresas que sonegam, que é favorecido pelas altas alíquotas do ICMS. Ou seja, muitos frigoríficos constituem uma firma oficial para fins fiscais, mantendo um nome permanente para uso externo, porém uma vez por ano, dão baixas na firma oficial e criam outra como forma de desfazer-se dos débitos fiscais. Dessa forma, frigoríficos bem como os pecuaristas, via seus órgãos representativos, têm proposto a redução do imposto e a sua equalização pelos estados, mas nem a União nem os Estados concordam com propostas que impliquem renúncia fiscal e perda de arrecadação. 
Um efeito esperado da redução do ICMS é a diminuição do abate clandestino. Mas vale observar que a clandestinidade não está apenas vinculada à cobrança do ICMS, mas também à cobrança de outros tributos e aos custos relativos ao atendimento da legislação sanitária.

Segundo Rezende ${ }^{12}$ (citado por IEL et al., 2000), o valor total pago de impostos pela cadeia será mais alto quanto maior for o número de transações e quanto maior for o valor adicionado nas primeiras etapas em relação às últimas.

A Tabela 12 mostra a evolução do abate informal de bovinos, na cadeia de carne bovina brasileira.

Tabela 12. Estimativas da evolução do abate informal de bovinos no Brasil ${ }^{13}$ (em milhões de cabeças)

\begin{tabular}{lccrr}
\hline Ano & $\begin{array}{c}\text { Abate total } \\
\text { (a) }\end{array}$ & $\begin{array}{c}\text { Abate } \\
\text { Inspecionado } \\
\text { (b) }\end{array}$ & $\begin{array}{c}\text { Abate informal } \\
(\mathrm{a})-(\mathrm{b})\end{array}$ & $\begin{array}{c}\text { Informalidade } \\
(\%)\end{array}$ \\
\hline 1997 & 34.187 .026 & 14.886 .260 & 19.300 .766 & 56 \\
1998 & 34.526 .168 & 14906476 & 19.619 .692 & 57 \\
1999 & 34.697 .079 & 16787031 & 17.910 .048 & 52 \\
2000 & 35.226 .299 & 17085617 & 18.140 .682 & 51 \\
2001 & 36.276 .308 & 18436299 & 17.840 .009 & 49 \\
2002 & 37.809 .754 & 19924046 & 17.885 .708 & 47 \\
2003 & 40.542 .921 & 21644403 & 18.898 .518 & 47 \\
\hline
\end{tabular}

Fonte: IBGE (2004) e FNP Consultoria \& Agroinformativos (2003)

Como pode observar na Tabela 12, a participação do abate informal no total abatido vem decrescendo, porém, de 1997 a 2000 teve uma participação superior a 50\%

\footnotetext{
${ }^{12}$ REZENDE, F. O peso dos impostos no custo da alimentação: análise do problema e propostas de redução. s.l.: Rezende e Accorsi Consultoria e Planejamento, 1991.

${ }^{13}$ Ressalta-se que as fontes de dados dos abates totais de bovinos e abates de bovinos inspecionados são distintos, o que leva a um viés na estimativa do abate informal.
} 
do total de bovinos abatidos, o que evidencia a concorrência desleal que as empresas formais sofrem em relação às clandestinas.

Segundo Bánkuti (2002), as tentativas por meio das portarias 304 e 145 e de redução de impostos na redução do abate e comercialização de carne bovina clandestina ainda apresentam resultados pequenos sobre o nível de informalidade.

Isso pode ser explicado, segundo o autor, pelo fato da redução tributária enfrentar um limite dado pela característica do produto, ou seja, a informalidade além de proporcionar um ganho fiscal também possibilita um ganho derivado do aproveitamento de carcaças que seriam descartadas por riscos sanitários ou falta de padrão. Em relação às portarias, as condições de enforcement são baixas, principalmente devido à deficiente fiscalização.

Destaca também que o mercado informal assenta em estruturas de governança específicas, como a integração vertical entre abate e distribuição e a relação de confiança estabelecida entre açougueiro e consumidor.

$\mathrm{O}$ aspecto cultural da população brasileira em adquirir carne com osso ou então presenciar a desossa e corte no local de compra é um exemplo típico de como os costumes e tradições (regras informais) dificultam o cumprimento das portarias, e além de conflitarem com as regras formais (leis e portarias), fornecem condições para transações clandestinas (Bánkuti \& Azevedo, 2004a).

Dessa forma, a falta de percepção do consumidor do valor da carne de qualidade, a ineficiente inspeção sanitária - o que conduz ao baixo enforcement juntamente com as regras informais, favorecem a presença de unidades clandestinas, o que dificultam uma maior coordenação vertical. 


\subsubsection{Sistema de inspeção sanitária}

O Sistema de Inspeção Sanitária, por meio da Lei 5.760/71, esteve sob total controle da esfera federal - Sistema de Inspeção Federal (SIF), até a promulgação da Lei 7.889/89, quando foi desmembrado em três níveis de atuação: federal, estadual e municipal.

Assim, o Sistema de Inspeção Federal (SIF) foi mantido na fiscalização de carnes comercializadas de um Estado para outro em todo território nacional e nas que se destinam às exportações. Criou-se o Sistema de Inspeção Estadual (SIE), que prioriza a comercialização de carnes no âmbito estadual, e o Sistema de Inspeção Municipal (SIM), que autoriza o controle da inspeção sanitária nos municípios (Bánkuti \& Azevedo, 2004a).

O Quadro 5 mostra as características desses Sistemas: 


\begin{tabular}{|l|l|l|l|}
\hline $\begin{array}{l}\text { Sistema de } \\
\text { Inspeção }\end{array}$ & Características & Aspectos Positivos & Aspectos Negativos \\
\hline SIF & $\begin{array}{l}\text { Autoriza a } \\
\text { comercialização de } \\
\text { carnes para o mercado } \\
\text { externo e todo o } \\
\text { território nacional }\end{array}$ & $\begin{array}{l}\text { Maior credibilidade no } \\
\text { mercado interno (grandes } \\
\text { redes varejistas dão } \\
\text { preferência ao SIF em } \\
\text { relação aos Sistemas } \\
\text { Estaduais). }\end{array}$ & $\begin{array}{l}\text { Maiores custos de } \\
\text { implantação e } \\
\text { burocracia }\end{array}$ \\
\hline SIE & $\begin{array}{l}\text { Permite a } \\
\text { comercialização de } \\
\text { carnes apenas dentro } \\
\text { dos limites de cada } \\
\text { Estado }\end{array}$ & $\begin{array}{l}\text { Menores custos de } \\
\text { implantação se } \\
\text { comparados ao SIF e } \\
\text { crescentemente ganha } \\
\text { credibilidade - no caso do } \\
\text { SISP }\end{array}$ & $\begin{array}{l}\text { Impossibilidade de } \\
\text { exploração do } \\
\text { mercado externo e de } \\
\text { outros estados. } \\
\text { Descrédito frente a } \\
\text { alguns segmentos de } \\
\text { mercado }\end{array}$ \\
\hline SIM & $\begin{array}{l}\text { Contempla a } \\
\text { comercialização de } \\
\text { carnes somente dentro } \\
\text { dos limites do } \\
\text { município sede do } \\
\text { abatedouro }\end{array}$ & $\begin{array}{l}\text { Alternativa para pequenos } \\
\text { e/ou produtores locais }\end{array}$ & $\begin{array}{l}\text { Vínculo aos poderes } \\
\text { políticos locais e } \\
\text { associação com } \\
\text { práticas clandestinas } \\
\text { de abate }\end{array}$ \\
\hline Clandestino & $\begin{array}{l}\text { Ilegal, e portanto, não } \\
\text { circunscritos às } \\
\text { fronteiras político } \\
\text { administrativas. }\end{array}$ & $\begin{array}{l}\text { Preço aproximadamente } \\
\text { 30\% inferior se } \\
\text { comparado com os abates } \\
\text { legais }\end{array}$ & $\begin{array}{l}\text { Diversos problemas de } \\
\text { ordem econômica e } \\
\text { social. Não existe } \\
\text { padronização e } \\
\text { qualidade do produto }\end{array}$ \\
\hline
\end{tabular}

Quadro 5 - Peculiaridades dos sistemas de inspeção sanitária para carnes no Brasil

Fonte: Bánkuti \& Azevedo (2004b)

(*) Sistema de Inspeção para o Estado de São Paulo

Segundo Cardoso (1998, apud Bánkuti \& Azevedo, 2004b), um dos principais problemas da cadeia é o fato do poder público contar com um quadro insuficiente de funcionários e possuir baixa capacidade de fiscalização, além da falta de recurso do Ministério da Agricultura para a inspeção.

Devido à incapacidade das três instâncias de inspeção, tem sido aceito pelo setor a criação de instituições independentes, como, por exemplo, Fundo de 
Desenvolvimento da Pecuária do Estado de São Paulo (FUNDEPEC) e Fundo de Erradicação da Febre Aftosa (FEFA) ${ }^{14}$.

Dessa forma, observa-se que houve um avanço na legislação sanitária, mas não foi acompanhada por uma fiscalização/inspeção eficiente, por falta de pessoal habilitado e de recursos do MAPA.

No que diz respeito à Febre Aftosa no Brasil, 15 estados - RO, MT, TO, GO, BA, SE, MG, ES, RJ, SP, MS, PR, SC, RS e DF - são atualmente zonas livres de febre aftosa com vacinação, com reconhecimento internacional da Organização Internacional de Epizootia (OIE), órgão da ONU para sanidade animal. O estado de Santa Catarina possui o certificado de zona livre de febre aftosa sem vacinação, com reconhecimento apenas nacional (Cavalcanti, 2004b).

O certificado de zona livre de febre aftosa serve como um selo de qualidade para os criadores. Os Estados Unidos utilizam a febre aftosa como uma barreira não tarifária, não reconhecendo apenas alguns estados como áreas livres, como permite o princípio da regionalização.

Os cortes nos orçamentos do setor público são uma ameaça ao sucesso da erradicação da doença no Brasil, tornando-se necessária a participação da iniciativa privada, através da união entre os agentes privados e entre estes e os estados. Tem-se como exemplo o FUNDEPEC criado em 1990, e com maior participação do estado foi criado o FEFA em 1993, no Mato Grosso.

\footnotetext{
${ }^{14}$ O FUNDEPEC foi criado em 1991 para, em parceria com a Secretaria da Agricultura, combater a Febre Aftosa no Estado de São Paulo, e em 1996 desenvolveu um projeto que mais tarde ficou conhecido como Aliança Mercadológica ou Programa Novilho Precoce. Em relação ao FEFA, a Federação da Agricultura e Pecuária do Estado de Mato Grosso (FAMATO) o criou em 1993 para atuar na Erradicação da doença Febre Aftosa.
} 
Segundo Cavalcanti (2004b), o Brasil precisa erradicar a aftosa na região nordeste do país. Grandes avanços têm sido feitos em relação à vacinação, mas ainda é preciso avançar mais. Um exemplo é o estado de São Paulo, que não apresenta focos desde 1996. O Uruguai conseguiu em maio de 2003 o reconhecimento como área livre de aftosa com vacinação pela OIE, que graças a um trabalho de rigoroso controle sanitário, conseguiu provar que oferece segurança. O Chile é muito rigoroso com suas importações de carne, e é o único país da América do Sul (junto com a Guiana) livre de aftosa sem vacinação.

Os EUA tornaram-se livres da doença de febre aftosa em 1929, e há mais de 60 anos não têm nenhum caso da doença, graças a um trabalho sério e principalmente através de um programa de cooperação com o México, para evitar aftosa neste país.

A Austrália, tradicional grande exportador de carne, tem um dos controles mais rígidos contra doenças contagiosas e não apresenta aftosa desde 1872. O Reino Unido preferiu abater milhões animais em 2001, após um surto da doença, e continuar com o status de livre de aftosa sem vacinação ao invés de retroceder ao status livre com vacinação. O Paraguai perdeu o status de área livre de febre aftosa no final de 2002 (Dois anos sem febre aftosa..., 2004).

O continente livre de febre aftosa significa abrir o acesso a mercados como o do Japão, que não admite a entrada de carne proveniente de países com febre aftosa, mesmo com vacinação (Simão, 2004).

Dessa forma, o país amplia os mercados importadores de sua carne bovina ao incorporar novas áreas livres de aftosa e tornar consolidada a defesa animal, sendo, assim, decisivo o reconhecimento do Brasil como país livre da febre aftosa, que exigirá esforços das autoridades e de produtores que atualmente são parceiros no processo de defesa animal (Tavares, 2004).

Numa entrevista, Rodrigues, ministro da agricultura, reforça a necessidade de atenção à defesa sanitária, para garantir conquistas no mercado externo, em que é 
preciso realizar a contratação emergencial de fiscais para atender às demandas originárias com a crise da vaca louca e de técnicos de nível superior. A câmara setorial da carne bovina trouxe resultados positivos, como por exemplo, a consolidação do SISBOV, conduzindo o processo junto com o MAPA, e todo trabalho de defesa sanitária também vem sendo conduzido em conjunto com a câmara setorial. (Futuro promissor para a pecuária..., 2004)

\subsection{Ambiente organizacional}

O ambiente organizacional do SAG da carne bovina brasileira compõe-se de entidades tanto públicas quanto privadas. Relacionam-se, a seguir, os principais programas e os responsáveis pelos mesmos.

\subsubsection{Programas e Alianças Mercadológicas}

O Quadro 5 mostra os principais componentes do Ambiente Organizacional do SAG de carne bovina brasileiro, que são os órgãos ativos em iniciativas de coordenação na cadeia de gado de corte: 


\begin{tabular}{|c|c|}
\hline Elos da Cadeia & $\begin{array}{c}\text { Órgãos de Classe/Associações privadas/Órgãos } \\
\text { governamentais }\end{array}$ \\
\hline Pecuária & $\begin{array}{l}\text { CNPC - Conselho Nacional da Pecuária de Corte } \\
\text { FNPPC - Fórum Nacional Permanente da Pecuária de Corte } \\
\text { (CNA) }\end{array}$ \\
\hline Abate/Frigorífico & $\begin{array}{l}\text { - ABIEC - Associação Brasileira das Indústrias de Carne } \\
\text { Industrializada } \\
\text { - ABIEF - Associação Brasileira das Indústrias Exportadoras de } \\
\text { Frios } \\
\text { - SINDIFRIO - Sindicato das Indústrias de Frio do Estado de } \\
\text { - São Paulo } \\
\text { - ABIF - Associação Brasileira da Indústria de Frigoríficos } \\
\text { - Abrafrigo - Associação Brasileira da Indústria Frigorífica }\end{array}$ \\
\hline Distribuição & $\begin{array}{l}\text { - SCVCF - Sindicato do Comércio Varejista de Carnes } \\
\text { Frescas do Estado de São Paulo }\end{array}$ \\
\hline Elos da Cadeia & Programas \\
\hline Pecuária & $\begin{array}{ll}\text { - } & \text { PNPC - Programa Novas Fronteiras do Cooperativismo } \\
\text { (Ministério da Agricultura e Abastecimento) } \\
\text { - FUNDEPEC - Fundo de Desenvolvimento da Pecuária do } \\
\text { Estado de São Paulo }\end{array}$ \\
\hline
\end{tabular}

Quadro 6 - Ambiente organizacional do sistema agroindustrial da carne bovina no Brasil Fonte: IEL (2000)

Algumas das organizações e programas são destacadas no quadro acima, têm como missões:

- ABIEC: defender os interesses do setor exportador de carnes bovinas nos âmbitos nacional e internacional, tentar reduzir as barreiras comerciais tarifárias e não-tarifárias, garantir a representação do setor nos fóruns nacionais e internacionais influenciando a tomada de decisões e o processo normativo e legislativo que afetam o comércio internacional de carnes bovinas (ABIEC, 2004); 
- FUNDEPEC: uma entidade sem fins lucrativos, criado em 1991 para, em parceria com a Secretaria da Agricultura, combater a Febre Aftosa no Estado de São Paulo;

- SINDIFRIO: representar todo o setor da indústria frigorífica na base territorial do Estado de São Paulo. Sem fins lucrativos é constituído para fins de estudo, coordenação, proteção e representação legal da categoria, integrada pelos matadouros, frigoríficos de bovinos, suínos, aves, animais exóticos e aves silvestres, sob regime de inspeção federal (Sindifrio, 2004);

Ressalta-se também a importância de organizações como a Câmara Setorial da Cadeia Produtiva da Carne Bovina, onde são planejadas as ações do setor, ou seja, o delineamento das futuras ações do setor através do debate entre governo e representantes da cadeia, e da Agência de Promoção de Exportações do Brasil (APEX), bem como de programas como o Programa Carrefour e South Brazilian Beef ${ }^{15}$.

A ausência de organismos de articulação sistêmica faz com que problemas presentes em determinados elos, ou comportamentos oportunistas de determinados agentes, comprometem o desempenho da cadeia como um todo (IPARDES et al., 2002). Assim, um esforço de coordenação tem sido realizado através de alianças mercadológicas, que geralmente estão atreladas ao programa de novilho precoce.

15 A marca South Brazilian Beef foi criada pelo Sebrae para promover a carne gaúcha. O Programa Carrefour traz a introdução do conceito de Garantia de Origem no Brasil, modernizando o manejo de produção, trazendo organização e atentando para outros conceitos como a responsabilidade social e ambiental, onde os fornecedores são selecionados depois que suas instalações e formas de trabalho são aprovadas, seguindo padrões rigorosos de qualidade, controle ambiental e responsabilidade social. 
No que se refere aos programas de novilho precoce, estes estão geralmente associados à formação de alianças mercadológicas entre produtores, frigoríficos e supermercados para a comercialização de carnes diferenciadas (IEL et al., 2000).

Segundo Pigatto et al. (2004), a Associação Brasileira de Novilho Precoce procurou conscientizar os criadores, autoridades governamentais e os segmentos industrial e comercial a agirem com vista à melhoria da produção e produtividade como também procurando ofertar uma carne de melhor qualidade aos consumidores.

Procura-se incentivar o abate de novilho através da redução do ICMS e/ou estabelecimento de linhas especiais de financiamento. Porém como em alguns Estados o ICMS já se encontra reduzido para a atividade, o ganho não representa um incentivo. Assim, o verdadeiro estímulo em participar deste programa não reside apenas na isenção de uma parte do ICMS na venda do boi aos frigoríficos, mas no fato do pecuarista poder ganhar simplesmente por estar vendendo um animal muito mais jovem e de melhor qualidade e do frigorífico poder obter um animal com maior rendimento de carcaça e de melhor qualidade.

Conforme o presidente da Associação Brasileira do Novilho Precoce, Constantino Ajimasto, desde 2002, vem ocorrendo um desinteresse e uma queda na oferta de novilhos precoces, pois o pecuarista que o vinha produzindo está desestimulado pelo não recebimento de um diferencial de preço, além da competição com a cana-de-açúcar e a soja (Pitombo, 2004).

Em relação às Alianças Mercadológicas, programas como a Aliança Mercadológica da Carne, do Fundo de Desenvolvimento da Pecuária do Estado de São Paulo (FUNDEPEC-SP), e Carne com Qualidade, do Rio Grande do Sul (RS), são esforços para aumentar o grau de coordenação da cadeia. O primeiro tem como objetivo estabelecer canais estáveis de distribuição de carne de boa qualidade via acordo entre pecuaristas, frigoríficos, transportadores e supermercados, para assegurar a qualidade do produto ao consumidor final, e numa segunda etapa, será instituída a certificação, introduzindo assim a rastreabilidade, e os produtos de melhor qualidade poderão obter 
preços diferenciados. O segundo tem como objetivos a recuperação da produção pecuária, o aumento do abate inspecionado, a redução da capacidade ociosa das empresas e a melhoria da qualidade dos produtos oferecidos à população, sendo o principal instrumento o incentivo fiscal. Nos países onde esse esforço encontra mais dificuldade, varejistas (principalmente supermercados), estão desenvolvendo marcas próprias para recapturar a confiança dos consumidores (Faveret Filho e Paula, 1997).

Entretanto, constatou-se que a dificuldade de se obter uma coordenação efetiva tem atrasado a montagem de um programa nacional de certificação de qualidade, sendo que esta ausência abre espaço para a proliferação de selos e marcas de qualidade, que poderá trazer prejuízo para o "marketing" da carne (IEL et al., 2000).

De acordo com IEL et al. (2000), verificou-se que os programas de novilho precoce e alianças mercadológicas envolvem conscientização e adesão de diferentes agentes e empresas da cadeia produtiva, e que essa conscientização implica na mudança da cultura de condução dos negócios em cada elo da cadeia e inclui um processo de aprendizagem de novas formas de competição e cooperação entre os agentes. Neste trabalho pretende-se via aplicação de questionários aos frigoríficos obter um maior conhecimento da situação atual desses programas.

Um fator importante na concretização desses programas é a mudança que deve ocorrer no comportamento de compra do consumidor final, pois se espera que aos poucos comece a experimentar e torne-se cliente do produto diferenciado.

\subsubsection{Algumas evidências sobre a especificidade do ativo}

Segundo Vinholis \& Azevedo (2000), as exigências dos consumidores europeus, refletidas no ambiente institucional, em relação à qualidade da carne, tornaram necessária a utilização de uma matéria-prima de maior confiança. 
Dessa forma, conforme relatado anteriormente, portarias foram implementadas pelo governo brasileiro, impondo requisitos ao fornecimento de carne, o que impulsionou a modernização da cadeia através da adoção de novas tecnologias de produto e processos. As Portarias 304 e 145, por exemplo, permitiram a geração de marcas próprias das unidades industriais, o que fortaleceu sua posição no mercado, vinculando sua imagem à qualidade dos produtos ofertados.

Em complemento às instituições, foram implementados programas de iniciativa privada e pública, como por exemplo, os programas de Aliança Mercadológica e Novilho Precoce, que também envolvem técnicas de produção específicas para poder ofertar um produto com atributos de qualidade que a diferencie da carne-commodity disponível no varejo (IEL et al., 2000).

Vinholis \& Azevedo (2000) dividiram o segmento em dois grupos estratégicos, em que o primeiro é formado por pecuaristas mais tecnificados, frigoríficos fiscalizados pelo SIF e que vendem para os super e hiper mercados nacionais e boutiques de carne ou para a exportação, e o segundo é composto por agentes menos tecnificados e clandestinos e que vendem para açougues tradicionais e feiras livres.

Contudo, as alterações não foram uniformes. Segundo IEL et al. (2000), verificou-se que os empresários das empresas frigoríficas estão investindo fortemente na reestruturação de suas unidades de produção. Outros investimentos em tecnologias de processamento, que representam uma agregação de valor à carne bovina, estão sendo feitos pelas empresas exportadoras e importantes empresas que atendem o mercado nacional. Observou-se também a implantação de novas unidades frigoríficas nos centros de produção animal, o que reduz os custos de transporte dos animais e os custos de obtenção de carne e derivados.

Assim, é interessante observar que, do ponto de vista teórico - teoria dos custos de transação (Williamson) e teoria do ambiente institucional (North) - as exigências do consumidor europeu conduziram a uma maior especificidade do ativo, mas o grau dessa especificidade varia de acordo com o tipo de investimento realizado. 
Dessa forma, o primeiro grupo - pecuaristas mais tecnificados, frigoríficos fiscalizados pelo SIF - caracteriza-se por investimentos mais específicos, o que leva a uma maior grau de especificidade de ativos do que o segundo grupo - agentes menos tecnificados e clandestinos.

Então, esperar-se-ia que para o primeiro grupo as transações fossem realizadas via contratos, enquanto que para o segundo grupo, as transações fossem feitas através do mercado, pois de acordo com a teoria, a medida que aumenta a especificidade do ativo, relações hierárquicas tornam-se mais eficientes, diminuindo, assim, os custos de transação.

Assim, torna-se importante a realização de uma pesquisa, com aplicação de questionários e entrevistas, de forma a permitir um conhecimento maior das alterações recentes do Sistema Agroindustrial da Carne Bovina, enfocando a especificidade dos ativos nos frigoríficos exportadores, pois são os primeiros a responderem às mudanças no ambiente e às exigências. 


\section{MATERIAL E MÉTODOS}

$\mathrm{Na}$ primeira etapa procede-se uma pesquisa exploratória, através de uma revisão de literatura sobre o tema em livros, artigos, revistas e sites especializados. Geralmente, as pesquisas exploratórias fazem parte da primeira etapa de uma investigação mais ampla, enquanto que o produto final desse processo passa a ser um problema passível de investigação via procedimentos mais sistematizados (Gil, 1997).

Em relação à segunda etapa, encaixa-se uma pesquisa de tipo descritiva. Segundo Gil (1999), esse tipo de pesquisa busca a descrição das características de determinada população ou fenômeno ou o estabelecimento de relações entre variáveis, e uma de suas características está na utilização de técnicas padronizadas de coleta de dados.

Porém, ressalta-se que nesta dissertação considera-se a formação da União Européia até 2003, que é composta pelos seus 15 Estados Membros - Alemanha, Áustria, Bélgica, Dinamarca, Espanha, Finlândia, França, Grécia, Irlanda, Itália, Luxemburgo, Países Baixos, Portugal, Reino Unido e Suécia - pois em 2004 houve a introdução de 10 países na sua composição. O motivo de considerar sua formação anterior é devido ao fato dos dados secundários (USDA, FAO, entre outros) ainda não divulgarem resultados da nova composição da UE.

Dessa forma, adicionalmente à pesquisa bibliográfica, surge nesse trabalho a necessidade de levantamento de dados primários, para a obtenção de informações sobre o modo de governança das transações dos frigoríficos exportadores, que se realiza por meio de aplicação de questionários, via e-mail e entrevistas, em que as conclusões 
correspondentes dos dados coletados são expostas através da utilização de um tratamento estatístico, visando a compreensão total do problema.

O trabalho terá como foco de estudo a relação entre os elos: frigorífico e fornecedor de boi (pecuária); frigorífico e varejo (mercado interno); frigorífico e mercado europeu.

A seguir, será apresentada a estrutura e as variáveis do questionário bem como a técnica utilizada para o tratamento estatístico dos dados obtidos.

\subsection{Obtenção de dados}

A aplicação de questionários direcionados às empresas frigoríficas de carne bovina que possuem Sistema de Inspeção Federal (SIF) e que são habilitadas a exportar para a União Européia, como forma de entendimento e maior explicitação dos principais aspectos relacionados à variação de estrutura de governança das transações.

Esses frigoríficos são pertencentes à Associação Brasileira das Indústrias Exportadoras de Carne (ABIEC), a qual é composta atualmente por 18 grupos frigoríficos, e representavam, em 2003, 84 \% do valor das exportações totais do Brasil (ABIEC, 2003), o que, portanto, aproxima-se da população, em que todas exportam para a UE. Porém para o presente trabalho, considerar-se-ão 17 grupos frigoríficos, pois a empresa Sadia se associou à ABIEC muito recentemente, voltando a exportar carne bovina há pouco tempo.

Cabe ressaltar a limitação da amostra aos frigoríficos exportadores, porém são nestes em que se refletem as prováveis alterações no ambiente institucional. Uma outra limitação seria a não realização de entrevistas com pecuaristas e varejistas, de modo a confrontar as informações prestadas. Contudo, dadas as limitações de tempo e de recursos, optou-se em analisar somente os dados oriundos dos questionários e entrevistas com os frigoríficos exportadores. 
A seguir, no Quadro 7, descrevem-se as empresas associadas à ABIEC, as quais serão pesquisadas.

\begin{tabular}{|l|l|}
\hline Empresas & Localização \\
\hline $\begin{array}{l}\text { Cooperativa Industrial de Carnes e } \\
\text { Derivados de Goiás Ltda }\end{array}$ & Senador Canedo - GO \\
\hline Frigoalta - Pádua Diniz Alimentos Ltda & São José do Rio Preto - SP \\
\hline Bertin Ltda e Bertin/Lins & Lins - SP \\
\hline Friboi Ltda & São Paulo - SP \\
\hline Frigoestrela - Frigorífico Estrela Ltda & Estrela D’Oeste - SP \\
\hline Frisa - Frigorífico Rio Doce S/A Alimentos Ltda e & Rio de Janeiro - RJ \\
\hline $\begin{array}{l}\text { Independência Nova } \\
\text { Independência Alimentos - Camar -SP } \\
\text { Andradina. }\end{array}$ & \\
\hline $\begin{array}{l}\text { Marfrig - Frigoríficos e Comércio de } \\
\text { Alimentos Ltda }\end{array}$ & Santo André - SP \\
\hline $\begin{array}{l}\text { Indústria e Comércio de Carnes Minerva } \\
\text { Ltda }\end{array}$ & Barretos - SP \\
\hline Quatro Marcos Ltda & Jandira - SP \\
\hline Frigorífico Vangélio Mondelli Ltda & Bauru - SP \\
\hline Frigorífico Margen Ltda & Rio Verde - GO \\
\hline $\begin{array}{l}\text { Brasboi - Bom Charque Indústria e } \\
\text { Comércio Ltda }\end{array}$ & São Paulo - SP \\
\hline Frigorífico Mataboi & Araguari - MG \\
\hline Frigorifico Marabá Ltda & Promissão - SP \\
\hline Frigorífico Riosulense S/A & Rio do Sul - SC \\
\hline SADIA S/A Pão Paulo - SP \\
\hline Frigorífico Mercosul S/A & Bagé - RS \\
\hline
\end{tabular}

Quadro 7 - Empresas associadas à ABIEC

Fonte: ABIEC (2004)

Quanto à aplicação dos questionários, pode-se aplicá-lo de duas formas: através de contato direto ou enviá-lo pelo correio, inclusive via e-mail. Por contato direto, pode-se explicar e abordar os objetivos da pesquisa, esclarecendo dúvidas dos entrevistados relacionadas às questões, enquanto que pelo correio ou e-mail permite incluir um número maior de pessoas na amostra, porém, apresenta como desvantagem a 
baixa taxa de devolução dos questionários, que por sua vez, podem trazer dúvidas nas respostas por falta de entendimento das questões (Barros \& Lehfeld, 2000).

Neste trabalho realizaram-se primeiramente entrevistas, entre agosto e outubro de 2004, baseadas no questionário, com 3 das 4 empresas frigoríficas com maior participação no valor total da exportação brasileira de carne bovina em 2003, dentre as associadas à ABIEC (uma delas não aceitou participar da pesquisa). Das 3 entrevistas realizadas, uma empresa respondeu parcialmente os questionários. Nota-se, dessa forma, a dificuldade em obter as informações.

Foram enviados os questionários por e-mail às 15 empresas restantes, em outubro de 2004, após contato por telefone. Houve a devolução de 6 questionários respondidos no prazo de um mês, e durante este prazo, ligações telefônicas foram sendo realizadas com o intuito de aumentar o número de respostas. Contudo, o número total de questionários respondidos é 9 , incluindo as 3 entrevistas realizadas, o que representa $53 \%$ da amostra. Ressalta-se que os questionários utilizados nas entrevistas possuem apenas 3 questões a mais que os questionários enviados por e-mail, o que permitiu agregar os dados comuns a todos.

Assim, a análise e discussão dos resultados são realizadas conjuntamente a partir das respostas obtidas nas entrevistas e questionários enviados, via análise estatística, pois abordam as mesmas informações, apenas as questões adicionais das entrevistas serão tratadas separadamente. Informações adicionais obtidas nas entrevistas quanto nos questionários enviados por e-mail, bem como as informações obtidas nos sites das respectivas empresas serão também acrescentadas. Algumas questões abertas são apresentadas com as respectivas respostas de cada frigorífico, pela dificuldade de tabulação e também para melhor entendimento da situação.

Tanto as empresas entrevistadas quanto as empresas que receberam por email os questionários serão chamadas por uma letra (A,B,C,D,E,F,G,H e I,) com o intuito de preservar suas identidades. 
Também são utilizados dados secundários, como por exemplo, dados do IBGE, USDA e FAO, para a realização do panorama da cadeia e dados obtidos nos sites dos frigoríficos associados à ABIEC.

\subsection{Estrutura e variáveis do questionário}

Esse item mostra de forma geral as principais variáveis que compõem os questionários. Ambos são compostos por 6 módulos (ver apêndice A), denominados respectivamente por características gerais, aspectos institucionais e organizacionais, relação com o fornecedor, relação com o varejo, relação com clientes europeus e produção. Serão apresentados, a seguir, os objetivos e variáveis de cada módulo dos questionários.

\subsubsection{Características gerais}

Esse módulo tem como objetivo a identificação e aspectos gerais da empresa, o qual engloba questões representadas pelas seguintes variáveis:

a) Nome da empresa: objetiva-se identificar a empresa, sendo que cada empresa será identificada, na dissertação, por letras do alfabeto, ou seja, os nomes das empresas serão mantidos em sigilo;

b) Tempo de funcionamento da empresa: pretende-saber quanto tempo a empresa atua no mercado;

c) Mercado atendido pela empresa: conhecer se o mercado atendido pela empresa é interno, externo ou ambos e a participação de cada na produção; 
d) Clientes internacionais: saber quais os clientes internacionais da empresa, o ano inicial de exportação para o país e quais as respectivas participações nas suas exportações.

\subsubsection{Aspectos institucionais e organizacionais}

Pretende-se, nesse módulo, retratar como as empresas estão lidando com as leis e portarias implementadas pelo governo, sua participação em programas de qualidade e em organizações. Este módulo tem como objetivo captar como as variações no ambiente institucional influenciaram a especificidade do ativo e o reflexo sobre as estratégias das empresas, principalmente no que se refere a coordenação do SAG. Esta seção contém as seguintes variáveis:

a) Rastreabilidade: Objetiva-se identificar se o boi comprado pela empresa possui rastreabilidade completa, parcial ou não a possui;

b) Programas de qualidade: pretende-se saber quais os programas de qualidade adotados pela empresa frente às exigências do consumidor e quais programas de qualidades exigidos pelo consumidor europeu, com respectivos anos de implementação;

c) Portarias: se a empresa tem dificuldade em atendê-las e também saber as dificuldades relacionadas especificamente ao SISBOV;

d) Como a EEB afetou os investimentos na empresa;

e) Exigências européias: conhecer as principais exigências dos clientes europeus em relação à matéria-prima boi, e saber se exigem mais do que consta na diretiva bem como se há novas exigências futuras;

f) Transgênicos: essa pergunta é especifica para as empresas entrevistadas. Saber se a ração do gado é composta por transgênicos. 
g) Alianças e Programas: tem como objetivo saber se a empresa participa de Aliança Mercadológica e Novilho Precoce;

h) Coordenação: saber a opinião da empresa sobre quem é o responsável pela coordenação do SAG da carne bovina.

\subsubsection{Relação com o fornecedor}

Este módulo se refere ao relacionamento da empresa com seus fornecedores da matéria-prima boi. Objetiva-se verificar se as formas das transações estão se alterando com a variação na especificidade dos ativos, que é o objetivo deste trabalho, bem como captar a freqüência da transação, incerteza e oportunismo. Destacam as seguintes variáveis:

a) Matéria-prima boi: conhecer como a empresa comprava boi (via mercado, via contratos ou outros modos) antes e depois de 1996 (com as exigências de qualidade e rastreabilidade), possibilitando captar a mudança na estrutura de governança da empresa, bem como saber o grau de aceitação do fornecedor em relação ao contrato e se cria boi para próprio fornecimento;

b) Quais medidas a empresa adota na compra de boi frente à febre aftosa;

c) Boi rastreado: saber se a empresa compra boi rastreado e se há a presença de contratos nessa compra, tanto para carne destinada ao mercado interno como para o externo. Verifica-se também se e quais incentivos a empresa oferece aos fornecedores de boi rastreado;

d) Freqüência, incerteza e oportunismo: busca-se verificar qual a freqüência de compra da empresa de fornecedores rastreados e não 
rastreado, as incertezas da empresa quanto ao ambiente e produto (boi) e se há oportunismo por parte do fornecedor;

e) Compra de boi: saber se a empresa compete com outros frigoríficos na compra de boi.

\subsubsection{Relação com o varejo}

Essa parte do questionário se refere ao relacionamento da empresa com seus clientes do mercado interno. Também objetiva verificar se as formas das transações estão se alterando com a variação na especificidade dos ativos, bem como captar a freqüência da transação, incerteza e oportunismo. Neste módulo destacam-se as seguintes variáveis:

a) Clientes internos: identificar quais os clientes - supermercados, boutiques de carne, açougues e outros - que a empresa atende no mercado interno e a participação de cada cliente nas vendas. As exigências dos clientes e a existência ou não de acordo entre a empresa e clientes também são captadas.

b) Contrato: busca-se saber se há contratos entre a empresa e seus clientes, e o tipo de contrato;

c) Freqüência, incerteza e oportunismo: busca-se verificar qual a freqüência de venda da empresa, as incertezas da empresa quanto ao ambiente e à venda do produto e se há oportunismo por parte dos compradores. 


\subsubsection{Relação com clientes europeus (União Européia)}

Neste módulo, pretende-se captar as exigências dos consumidores europeus quanto à qualidade do produto, de modo que cada alternativa refere-se a todos clientes. As variáveis são explicadas a seguir:

a) Tempo de exportação: saber a quanto tempo a empresa exporta para a UE, por que optou por esse mercado, qual a participação dessa exportação na produção da empresa e se a empresa exporta diretamente ou utiliza traders;

b) Tipo de carne exportada: conhecer o tipo de carne - in natura, industrializada ou ambas - exportada à UE, bem como o tipo de corte, em que este só é perguntado na entrevista;

c) Clientes europeus: pretende-se saber quem são os clientes europeus (rede de supermercados, atacadistas, empresas processadoras, distribuidoras e outros)e suas respectivas participações na quantidade vendida;

d) Segurança do alimento: busca-se conhecer o nível de preocupação do cliente europeu em relação à segurança do alimento (apenas realizada nas entrevistas);

e) Opinião da empresa: verificar a opinião da empresa quanto às exigências dos clientes europeus (apenas realizada nas entrevistas);

f) Medidas adotadas: objetiva-se conhecer as principais medidas adotadas pelas empresas para atender as exigências de seus clientes;

g) Atuação do setor público: busca-se captar o que a empresa está demandando do setor público; 
h) Contrato: busca-se saber se há contratos entre a empresa e seus clientes europeus, e o tipo de contrato;

i) Freqüência, incerteza e oportunismo: busca-se verificar qual a freqüência de venda da empresa, as incertezas da empresa quanto ao ambiente e à venda do produto e se há oportunismo por parte dos compradores europeus.

\subsubsection{Produção}

Esta parte do questionário compõe-se de 5 questões. Pretende-se, nesse módulo, conhecer a estrutura produtiva da empresa, em que as variáveis utilizadas são: abate total, receita total e exportação total e para a UE, bem como o faturamento anual da empresa e origem do capital.

\subsection{Análise dos dados}

Segundo Barros \& Lehfeld, (2000), uma vez selecionados os dados para interpretação e análise, os passos seguintes são: classificação, codificação e tabulação. Nessa fase, os dados são examinados e transformam-se em elementos essenciais para a comprovação ou não das hipóteses.

A classificação é uma forma de distribuir e selecionar os dados obtidos, reunindo-os em grupos, de acordo com o objetivo da pesquisa. Em relação à codificação, é um processo utilizado para a colocação de cada informação em categorias, dando-lhes um símbolo (letra do alfabeto ou número). Quanto à tabulação, é um processo pelo qual se apresentam os dados obtidos da categorização em tabelas.

Com base em Barros \& Lehfeld (2000), a análise dos dados decorrentes tem um tratamento estatístico, em que com a colaboração de quadros e tabelas efetua um 
tratamento quantitativo, enquanto que nas questões com dificuldades para a categorização, como as do tipo abertas, analisá-se o conteúdo para depois elaborar categorias, facilitando a tabulação das mesmas.

Dessa forma, a análise estatística dos dados dos questionários é feita utilizando a análise univariada, em que o primeiro passo para se entender o comportamento de uma variável em relação aos elementos observados é a construção de uma distribuição de freqüências (Dörr, 2003).

Este tipo de distribuição compreende a organização dos dados de acordo com as ocorrências dos diferentes resultados observados. Para a construção de uma distribuição de freqüências com dados de uma variável qualitativa, é preciso somente contar a quantidade de resultados observados em cada categoria, podendo-se também apresentar uma medida relativa de freqüência. Estas percentagens são obtidas dividindose a freqüência de cada categoria pelo número total de observações e, em seguida, multiplica-se por 100 (Dörr, 2003).

\subsection{Problemas relativos à pesquisa}

Como o questionário envolvia questões pertinentes a diferentes setores da empresa, precisava se deslocar para os outros setores. Então, este foi enviado a um dos setores, e observou-se que este foi encaminhado para os demais, ou as pessoas que pertenciam ao setor enviado entraram em contato com os responsáveis pelos outros setores para obter as respostas que não estariam ao seu alcance.

Houve algumas dificuldades em obter as informações, mesmo com o apoio da ABIEC e com os esclarecimentos a cada frigorífico associado sobre a seriedade e importância desta pesquisa. 
As entrevistas serviram para testar o questionário, e notou-se que todas as respostas das questões relacionadas aos clientes europeus valiam para todos os clientes assinalados. Assim, explica-se a decisão em não dividir as questões por categorias de clientes europeus. 


\section{RESULTADOS E DISCUSSÃO}

Neste capítulo serão apresentados os resultados dos questionários e entrevistas realizadas com as 9 empresas frigoríficas exportadoras para a União Européia, que serão nomeadas por uma letra, se extendendo de A até I, com a finalidade de preservar a identidade das mesmas. A discussão e análise serão feitas seguindo os módulos do questionário.

\subsection{Características gerais}

Quanto à caracterização geral das empresas, 100\% das 9 que participaram da pesquisa são de capital nacional, a maioria são empresas familiares, em que o faturamento anual destas empresas variam de menos de $\mathrm{R} \$ 300$ milhões até para mais de R\$ 1 milhão. É interessante notar a ausência de capital estrangeiro na indústria frigorífica, a despeito das baixas barreiras à entrada existentes (requerimentos de capital). Este fato pode ser explicado pela presença do mercado clandestino de carnes, que torna a competição entre as empresas formais (incluindo-se aí as possíveis entrantes de capital externo) e informais desleal.

A Tabela 13 mostra o tempo de exercício no mercado das respectivas em presas. 
Tabela 13. Data de fundação da empresa

\begin{tabular}{lcc}
\hline Data de Fundação & Freqüência & Percentagem \\
\hline Década de 40 & 1 & 11,1 \\
Década de 50 & 2 & 22,2 \\
Década de 70 & 3 & 33,3 \\
Década de 80 & 2 & 22,2 \\
Década de 90 & 1 & 11,1 \\
\hline
\end{tabular}

Fonte: dados da pesquisa

Nota-se pela Tabela 13 que as 9 empresas foram fundadas em diversas décadas, ou seja, o tempo de exercício no mercado são muito distintos, sendo a maioria, $33,3 \%$, fundada na década de 70 .

Tabela 14. Mercado atendido e participação na produção em 2003

\begin{tabular}{lcc}
\hline Mercado atendido & Freqüência & Percentagem \\
\hline Só mercado interno & 0 & 0,0 \\
Só mercado externo & 0 & 0,0 \\
Ambos & 9 & 100,0 \\
Total & 9 & 100,0 \\
& Freqüência & Percentagem \\
Participação (\%) & & \\
mercado interno & 3 & 33,3 \\
$0<\mathrm{x}<50 \%$ & 2 & 22,2 \\
Exatamente 50\% & 3 & 33,3 \\
Mais de 50\% & 1 & 11,1 \\
Não respondeu & 9 & 100,0 \\
Total & & \\
& Freqüência & \\
Participação (\%) & & \\
mercado externo & 3 & 33,3 \\
$0<x<50 \%$ & 2 & 22,2 \\
Exatamente 50\% & 3 & 33,3 \\
Mais de 50\% & 1 & 11,1 \\
Não respondeu & 9 & 100,0 \\
Total & & \\
\hline
\end{tabular}

Fonte: dados da pesquisa 
Como pode visualizar na Tabela 14, das 9 empresas pesquisadas, $100 \%$ atendem tanto o mercado interno quanto o mercado externo, o que pode ser explicado pela necessidade de ajuste ou arbitragem dos volumes/receitas entre o mercado externo e interno das empresas ${ }^{16}$, para conseguirem fechar suas contas no final de cada período. Quanto à participação do mercado interno na produção total das empresas, nota-se que para 33,3\% das empresas o mercado interno responde por parcela entre 0 a $50 \%$, para $22 \%$ das empresas o mercado interno é responsável por $50 \%$ da produção, sendo que para $33 \%$ das empresas ele responde por mais de 50\%. A mesma é verificada na participação do mercado externo na produção total das empresas.

As Tabelas 15 e 16 mostram os clientes externos da empresas com suas respectivas participações na quantidade exportada em 2003.

Tabela 15. Clientes externos

\begin{tabular}{lcc}
\hline Clientes externos & Freqüência & Percentagem \\
\hline UE & 9 & 100,0 \\
EUA & 3 & 33,3 \\
Oriente Médio & 9 & 100,0 \\
Ásia & 9 & 100,0 \\
Outros & 7 & 77,8 \\
Total & 9 & 100,0 \\
\hline
\end{tabular}

Fonte: dados da pesquisa

Conforme a Tabela 15, nota-se que das 9 empresas, $100 \%$ exportam para a UE, $100 \%$ para o Oriente Médio, $100 \%$ para a Ásia, $33,3 \%$ para os EUA e $77 \%$ exportam para outros países, dentre eles África (Costa Marfim, Argélia), América do Sul (Chile, Peru), Rússia, Canadá. Nota-se que as empresas possuem uma diversificação de mercados, atendendo clientes praticamente em todos os continentes. A participação das

\footnotetext{
${ }^{16}$ Muitas vezes as empresas vendem ao mercado externo determinados tipos de cortes, tendo que vender internamente as demais partes do boi.
} 
empresas no mercado norte americano é pequena devido ao fato deste país só importar carne industrializada do Brasil, por não reconhecer regiões livres de febre aftosa.

Tabela 16. Participação dos clientes externos na quantidade exportada em 2003

\begin{tabular}{|c|c|c|c|c|c|}
\hline \multirow[t]{2}{*}{ Empresas } & \multicolumn{5}{|c|}{$\begin{array}{c}\text { Clientes externos } \\
\text { Participação (\%) na quantidade exportada de } 2003\end{array}$} \\
\hline & UE & EUA & $\begin{array}{l}\text { Oriente } \\
\text { Médio }\end{array}$ & Ásia & Outros \\
\hline $\mathrm{A}$ & 35 & 0 & 40 & 5 & 20 \\
\hline B & 50 & 0 & 30 & 20 & 0 \\
\hline $\mathrm{C}$ & 40 & 11,4 & 40 & 4,3 & 4,3 \\
\hline D & - & - & - & - & - \\
\hline E & 28 & 0 & 29 & 43 & 0 \\
\hline $\mathrm{F}$ & - & - & - & - & - \\
\hline G & - & - & - & - & - \\
\hline $\mathrm{H}$ & - & - & - & - & - \\
\hline I & 40 & 25 & - & - & 25 \\
\hline
\end{tabular}

Fonte: dados da pesquisa

- não respondeu

A participação do destino das exportações das empresas pesquisadas mostra que apenas as duas empresas, $\mathrm{B}$ e I, das 5 que responderam este item do questionário, exportam mais para a UE. A empresa $\mathrm{C}$ exporta praticamente a mesma quantidade para a UE e Oriente Médio, a empresa A exporta 5\% a mais para o Oriente Médio em relação à UE e a empresa E tem como principal mercado a Ásia.

Observa-se na Tabela 17 que as empresas iniciaram suas exportações aos clientes externos a partir da década de 90, com exceção da empresa I, que iniciou suas exportações para a UE em 1983, ou seja, antes do evento da "vaca-louca" surgir. Dessa forma, nota-se que as empresas quem mais exportam para a UE, como é o caso da empresa I, são os que exportam há mais tempo para este bloco. 
Tabela 17. Ano inicial de exportação aos clientes externos

\begin{tabular}{|c|c|c|c|c|c|}
\hline \multirow[t]{2}{*}{ Empresas } & \multicolumn{5}{|c|}{$\begin{array}{c}\text { Clientes externos } \\
\text { Ano inicial de exportação }\end{array}$} \\
\hline & UE & EUA & $\begin{array}{l}\text { Oriente } \\
\text { Médio }\end{array}$ & Ásia & Outros \\
\hline $\mathrm{A}$ & 1996 & & - & - & - \\
\hline B & 1998 & & 1996 & 1998 & \\
\hline $\mathrm{C}$ & 1994 & 1994 & 1994 & 1994 & 1994 \\
\hline D & 2001 & & 1996 & 1996 & 2001 \\
\hline $\mathrm{E}$ & 2000 & & 2000 & 1988 & 2001 \\
\hline $\mathrm{F}$ & 2000 & & 2000 & 2000 & \\
\hline $\mathrm{G}$ & - & - & - & - & - \\
\hline $\mathrm{H}$ & - & - & - & - & - \\
\hline I & 1983 & - & - & - & - \\
\hline
\end{tabular}

Fonte: dados da pesquisa

- não respondeu

\subsection{Aspectos institucionais e organizacionais}

Esta seção tem como objetivo analisar as mudanças organizacionais e institucionais e conhecer os programas de qualidade exigidos pelos clientes e o comportamento da empresa frente a essas exigências.

A Tabela 18 mostra que $71,4 \%$ de 7 empresas participam de Programas de Novilho Precoce ou de Aliança Mercadológica, fornecendo uma carne de melhor qualidade aos clientes e obtendo em troca um preço maior, e apenas 28,6\% não participam. Ressalta-se que a participação em Programa de Novilho Precoce ou Alianças Mercadológicas possibilita uma maior coordenação da cadeia, e adoção de relações mais hierárquicas, a fim de que as exigências de qualidade sejam cumpridas. 
Tabela 18. Participação da empresa em alianças mercadológicas ou programas de novilho precoce

\begin{tabular}{lcc}
\hline & Freqüência & Percentagem \\
\hline Sim & 5 & 71,4 \\
Não & 2 & 28,6 \\
Total & 7 & 100,0 \\
\hline
\end{tabular}

Fonte: dados da pesquisa

Em relação à responsabilidade da coordenação da cadeia de carne bovina (Tabela 19) 42,9\% de 7 empresas que responderam acham que é do governo, por ter condições em dar incentivos via impostos (ICMS), por ter meios para coordenar e inspecionar, e por ter uma neutralidade de interesse. Por sua vez $28,6 \%$ disseram que a responsabilidade deve ser dos frigoríficos exportadores, por terem melhor conhecimento do negócio; 14,3\% consideram os produtores são os responsáveis, por estarem mais próximos do "produto", podendo dessa forma coordenar de perto a criação e venda do boi e $14,3 \%$; responderam que devem ser os frigoríficos em geral.

Nota-se, dessa forma, a importância que as empresas dão ao governo como agente responsável pela coordenação, uma vez que o governo pode controlar os tributos incidentes na cadeia e ditar regras formais (leis, portarias), destacando seu papel no combate à clandestinidade do setor. Contudo, ressalta-se que embora o governo atue de forma acentuada no controle e combate à doenças de bovinos, ou seja, na vigilância sanitária, esperar que o mesmo faça a coordenação de toda a cadeia produtiva certamente não é a ação mais adequada.

As empresas responderam também que é preciso ter diferencial no preço da carne bovina para poder estreitar laços com produtores, no sentido de agregar valor à carne bovina, e que todos os elos têm que participar e ter interesse no mercado, de forma que o modo de pensar que o mercado interno não precisa ter qualidade é um grande erro, e que o governo tem que continuar ditando regras. 
Tabela 19. Responsável pela coordenação

\begin{tabular}{lcc}
\hline & Freqüência & Percentagem \\
\hline Governo & 3 & 42,9 \\
Produtores & 1 & 14,3 \\
Frigoríficos exportadores & 2 & 28,6 \\
Frigoríficos em geral & 1 & 14,3 \\
Varejo & 0 & 0,0 \\
Órgãos de classe & 0 & 0,0 \\
Outros & 0 & 0,0 \\
Total & 7 & 100,0 \\
\hline
\end{tabular}

Fonte: dados da pesquisa

Em relação aos incentivos dados para ocorrer a coordenação entre frigoríficos e pecuaristas de boi, notou-se que os frigoríficos esperam incentivos fiscais do governo e agregação de valor à carne que vendem como principais fatores para que seja possível estabelecer uma melhor coordenação da cadeia, ou seja, melhores mecanismos para regular as transações. Contudo, observa-se que estes fatores não são as melhores estratégias para melhorar a coordenação entre estes elos. Para tanto, são necessários incentivos ao produtor de boi, dado pelo frigorífico, em que este já recebe incentivo da UE ao receberem um preço melhor pela carne bovina exportada.

É preciso que o suprimento da matéria-prima boi seja em qualidade e quantidade necessárias para viabilizar o esforço de diferenciação da carne bovina, principalmente no atendimento às exigências do cliente europeu, que por sua vez agregam valor à carne, o que gera a necessidade e estabelecimento de relações mais restritas entre os elos da cadeia.

Em relação à rastreabilidade, a Tabela 20 mostra que das nove empresas pesquisadas todas têm um determinado nível: 77,8\% possuem rastreabilidade parcial, ou, seja, iniciada com o animal já vivo, sendo implantada tanto na recria quanto na engorda, e 22,2\% adotam rastreabilidade total, que é iniciada no nascimento do animal. Dentre as empresas que possuem rastreabilidade parcial, algumas já abatem quase que $100 \%$ de animais totalmente rastreados, assim, logo terão um nível de rastreabilidade total. 
Tabela 20. Nível de rastreabilidade

\begin{tabular}{lcr}
\hline Nível de rastreabilidade & Freqüência & Percentagem \\
\hline Total & 2 & 22,2 \\
Parcial & 7 & 77,8 \\
Não possui & 0 & 0,0 \\
Total & 9 & 100,0 \\
\hline
\end{tabular}

Fonte: dados da pesquisa

Nota-se na Tabela 21 que das 9 empresas que responderam a questão, todas adotam rastreabilidade, HACCP (sistema que permite identificar, avaliar e controlar perigos que comprometem a sanidade dos alimentos), BPF (procedimentos necessários para assegurar alimentos inócuos e saudáveis), e 22,2\% adotam ISO 9000 (estabelece os requisitos para assegurar a qualidade dos processos de produção). Cerca de $88,9 \%$ das 9 empresas adotam outros programas, como PPHO (Procedimento Padrão de Higiene Operacional - evita a contaminação direta ou cruzada ou adulteração dos produtos através das superfícies dos equipamentos, utensílios, instrumentos de processo e manipuladores de alimentos), POP (Procedimentos Operacionais Padronizados), Programa de Controle de Organismos Geneticamente Modificados (OGM), Programa de Abate Humanitário (dentro dos padrões do bem-estar animal). Porém, vale mencionar que as BPF e PPHO são pré-requisitos essenciais para a implantação do HACCP.

Assim, nota-se que houve um grande aumento da especificidade dos ativos das empresas frigoríficas, principalmente do ativo carne bovina quando comparado à carne bovina commodity. Cabe destacar que a adoção destes programas de qualidade exigiu investimentos específicos por parte das empresas para atender às exigências de determinados países, e, portanto as empresas terão uma perda de renda se precisarem exportar para países que não os exigem (ou como quando têm de escoar sua produção para o mercado interno). 
Tabela 21. Programas de qualidade adotados pela empresa

\begin{tabular}{lcc}
\hline Programas & Freqüência & Percentagem \\
Rastreabilidade & 9 & 100,0 \\
HACCP & 9 & 100,0 \\
ISO 9000 & 2 & 22,2 \\
BPF & 9 & 100,0 \\
Outros & 8 & 88,9 \\
\hline
\end{tabular}

Fonte: dados da pesquisa

A Tabela 22 mostra que as empresas A, D e E implantaram programas de qualidade a partir do ano 2000, enquanto que as empresas B, C e F, implantaram-nas a partir no final da década de 90 .Observa-se que a maioria das empresas implementou em anos diferentes o mesmo programa de qualidade, além disso, para algumas empresas, a adoção destes programas ocorreu em data diferente do marco legal exigido pelo Brasil (HACCP em 1998, BPF em 2000 e rastreabilidade em 2002).

Tabela 22. Ano de implementação das medidas de qualidade adotadas

\begin{tabular}{|c|c|c|c|c|c|}
\hline \multirow[t]{2}{*}{ Empresas } & \multicolumn{5}{|c|}{ Ano de implementação dos programas de qualidade adotados pela empresa } \\
\hline & $\begin{array}{l}\text { RASTREABI- } \\
\text { LIDADE }\end{array}$ & HACCP & ISO 9000 & BPF & OUTROS \\
\hline A & 2002 & 2003 & & 2000 & $2000 / 2001$ \\
\hline B & 2001 & 2000 & & 1999 & \\
\hline $\mathrm{C}$ & 2000 & 1997 & & 1997 & 1997 \\
\hline $\mathrm{D}$ & 2001 & 2002 & & 2000 & \\
\hline $\mathrm{E}$ & 2003 & 2000 & & 2000 & \\
\hline $\mathrm{F}$ & 2003 & 1998 & 2005 & 2002 & \\
\hline G & - & - & - & - & - \\
\hline $\mathrm{H}$ & - & - & - & - & - \\
\hline $\mathrm{I}$ & - & - & - & - & - \\
\hline
\end{tabular}

Fonte: dados da pesquisa

- não respondeu 
A Tabela 23 mostra que todos os clientes europeus das 9 empresas pesquisadas exigem HACCP, 77,8\% das empresas disseram que seus clientes exigem BPF e no que diz respeito à rastreabilidade, 33,3\% das empresas têm como exigência a rastreabilidade total e $66,7 \%$ têm como exigência a rastreabilidade parcial.

Vale mencionar que todos os animais para exportação à UE têm, obrigatoriamente, de ser rastreados, seguindo as especificações do $\operatorname{SISBOV}^{17}$, e que, por enquanto, a UE está aceitando a rastreabilidade parcial, mas a expectativa é que em 2005 exija rastreabilidade total.

Quanto a outros programas de qualidade exigidos pelos clientes europeus, $44,4 \%$ das empresas responderam ter necessidade de implantação, tais como Controle Integrado de Pragas, Maturação Sanitária, Controle de Vidros e Programa de Abate Humanitário (dentro das normas de bem-estar animal). Acontece também Dos clientes europeus enviarem circulares através do MAPA com exigências específicas - em que há verificação de sua implantação, na maioria, através de auditorias. A missão sanitária da UE realiza auditoria uma vez ao ano nas empresas.

Tabela 23. Programas de qualidade exigidos pelos europeus

\begin{tabular}{llcc}
\hline Programas & & Freqüência & Percentagem \\
\hline HACCP & 9 & 100,0 \\
ISO9000 & 0 & 0,0 \\
Rastreabilidade & Total & 3 & 33,3 \\
& Parcial & 6 & 66,7 \\
& nenhum & 0 & 0,0 \\
BPF & & 7 & 77,8 \\
Outros & & 4 & 44,4 \\
\hline
\end{tabular}

Fonte: dados da pesquisa

${ }^{17}$ Apesar do SISBOV prever rastreabilidade total, existe um acordo coma UE permitindo exportações de animais com rastreabilidade parcial até 2005 , quando serão emitidas as novas regras. 
A Tabela 24 mostra as repostas das empresas quanto ao ano de exigência da UE. Nota-se que as empresas responderam anos diferentes para o mesmo programa de qualidade.

Tabela 24. Ano de exigência pela UE dos programas de qualidade

\begin{tabular}{|c|c|c|c|c|c|c|c|}
\hline \multirow[t]{3}{*}{ Empresas } & \multicolumn{7}{|c|}{ Programas } \\
\hline & НACCP & ISO9000 & & Rastreabi & dade. & $\mathrm{BPF}$ & Outros \\
\hline & & & total & parcial & nenhum & & \\
\hline $\mathrm{A}$ & 2003 & & & 2002 & & 2000 & $2000 / 1996$ \\
\hline B & 2000 & & & 2001 & & 1999 & \\
\hline $\mathrm{C}$ & 1997 & & & 2000 & & 1997 & 1997 \\
\hline $\mathrm{D}$ & - & & - & - & - & - & \\
\hline $\mathrm{E}$ & - & & & 2003 & & & \\
\hline $\mathrm{F}$ & 1998 & & & 2003 & & & \\
\hline G & - & & & - & & - & \\
\hline $\mathrm{H}$ & - & & - & & & - & \\
\hline I & - & & - & & & - & - \\
\hline
\end{tabular}

Fonte: dados da pesquisa

- não respondeu

Comparando as Tabelas 22 e 24, as respostas obtidas pelas empresas mostram que o ano em que os clientes europeus exigiram determinados programas de qualidade corresponde ao mesmo ano de suas implementações na empresa, o que evidencia que os frigoríficos adequaram a estrutura tecnológica e produtiva com o padrão internacional, para não perderem seus clientes europeus. Porém, o ano de exigência dos programas de qualidade da UE estabelecido na diretiva difere-se do ano de exigência respondido pelas empresas.

Em relação às portarias impostas que as empresas consideram difícieis de atender, a tabela 25 indica que dos 8 frigoríficos que responderam esta questão, nenhum tem dificuldade em atender portarias implementadas pelo governo. 
Tabela 25. Portaria com dificuldade em atender

\begin{tabular}{lcc}
\hline Dificuldade & Freqüência & Percentagem \\
\hline Nenhuma & 8 & 100,0 \\
Possui & 0 & 0,0 \\
Total & 8 & 100,0 \\
\hline
\end{tabular}

Fonte: dados da pesquisa

Alguns acrescentaram que a dificuldade não é atendê-las, mas o prazo curto para implementá-las e que estando a empresa sob Inspeção Federal e sendo Indústria de Alimentos, necessariamente todas as exigências têm que ser cumpridas.

\begin{tabular}{|l|l|}
\hline Empresas & \multicolumn{1}{|c|}{ Respostas } \\
\hline A & $\begin{array}{l}\text { No documento do SISBOV não vem especificado o nome da } \\
\text { certificadora }\end{array}$ \\
\hline B & - \\
\hline C & Relacionadas aos produtores em atendê-lo \\
\hline D & Conscientização do produtor \\
\hline E & $\begin{array}{l}\text { A empresa respondeu que não há nenhuma dificuldade, porém, o } \\
\text { SISBOV ainda apresenta falhas em sua estrutura por estar em fase de } \\
\text { implantação. }\end{array}$ \\
\hline F & - \\
\hline G & - \\
\hline H & - \\
\hline I & $\begin{array}{l}\text { As dificuldades maiores estão nos produtores, nas fabricas de brincos e } \\
\text { até mesmo nas certificadoras em cumprir a norma do SISBOV, que } \\
\text { tudo isto acaba refletindo na empresa frigorífica. Há também o } \\
\text { problema de divulgação do governo sobre o sistema aos fornecedores } \\
\text { de boi, que encaram como marketing dos frigoríficos, pois estes } \\
\text { tiveram que repassar como rastrear aos fornecedores. }\end{array}$ \\
\hline
\end{tabular}

Quadro 8 - Dificuldades da empresa em atender o SISBOV

Fonte: dados da pesquisa

- não respondeu 
Em relação ao SISBOV, nota-se que as dificuldades estão relacionadas principalmente aos fornecedores de boi em atendê-lo, porém ressalta-se que este sistema apresenta falhas em sua implantação, o que tem gerado discussões e conflitos entre os elos da cadeia, principalmente entre frigoríficos exportadores e pecuaristas, dificultando uma maior coordenação vertical.

Ressalta-se que embora muitas empresas digam que compram bois com rastreabilidade total, a grande parte dos pecuaristas que dizem possuir bois com esta especificidade na verdade podem não a possuir, ou seja, podem estar vendendo um boi com rastreabilidade parcial (ou mesmo não rastreado), como se fosse um produto com rastreabilidade total, pelo fato de não conseguirem seguir rigidamente as normas estabelecidas no SISBOV. Este fato a mostra a necessidade de um maior enforcement por parte da UE e do governo brasileiro sobre os frigoríficos e pecuaristas. Assim, essa falta de enforcement conduz ao pequeno aumento da especificidade, e, portanto, ao pequeno aumento dos custos de transação, o que pode levar a não adoção de contratos formais.

Quanto à doença da vaca-louca (Quadro 9), observa-se dentre os frigoríficos que responderam que esta doença pouco afetou a estrutura e investimentos na empresa. Uma explicação para isso seria o fato do gado brasileiro ter alimentação a pasto, o que impede a disseminação da enfermidade. Contudo, é interessante observar a pequena preocupação com uma questão essencial no atendimento dos mercados consumidores externos. Destaca-se a atuação do MAPA na adoção de medidas de prevenção e controle dessa doença. 


\begin{tabular}{|l|l|}
\hline Empresas & \multicolumn{1}{|c|}{ Respostas } \\
\hline A & $\begin{array}{l}\text { Esta doença sempre traz repercussão negativa para o setor, uma vez que as } \\
\text { pessoas passam a consumir menos carne e isso interfere no faturamento da } \\
\text { empresa }\end{array}$ \\
\hline B & Não houve investimentos neste sentido \\
\hline C & No HACCP teve que prever alguns cuidados direcionados ao problema \\
\hline D & Em nada \\
\hline E & $\begin{array}{l}\text { Não afetou significamente. Apenas num primeiro momento houve retração } \\
\text { de alguns mercados, mas revertida imediatamente }\end{array}$ \\
\hline F & Em nada \\
\hline G & Não afetou os investimentos, apenas foram mais cautelosos \\
\hline H & - \\
\hline I & - \\
\hline
\end{tabular}

Quadro 9 - Impacto da doença da vaca-louca sobre a estrutura/investimentos na empresa Fonte: dados da pesquisa

- não respondeu

No que se refere às exigências do cliente europeu quanto à matéria-prima boi, a Tabela 26 mostra que de 8 empresas, 100\% têm como exigência a não utilização de hormônios, 62,55\% a não utilização de ingredientes de origem animal, 62,5\% a não utilização de antibióticos (pode usar desde que respeite a quarentena antes do abate e utilize antibióticos controlados e aprovados pelo MAPA e pelos países importadores) e $12,5 \%$ das empresas responderam que há outros tipos de exigências. Essas exigências tornam o boi um ativo cada vez mais específico.

Tabela 26. Exigências dos clientes europeus quanto à matéria- prima boi

\begin{tabular}{lcc}
\hline Exigências & Freqüência & Percentagem \\
\hline Não usar hormônios & 8 & 100,0 \\
Não usar ingredientes de origem animal & 5 & 62,5 \\
Não usar antibióticos & 5 & 62,5 \\
Outro & 1 & 12,5 \\
\hline
\end{tabular}

Fonte: dados da pesquisa 
Nas entrevistas, foi perguntado sobre a compra de boi alimentado com ração composta por transgênicos, em que apenas 2 responderam. Em ambas as empresas, pessoas do departamento de qualidade disseram que não compram boi alimentado com ração composta por transgênicos, porém, pessoas da compra de boi disseram que não perguntam na compra, pois a maioria dos bois que compram são alimentados a pasto, o que leva a concluir que existem controvérsias dentro da própria empresa entre os setores.

Observa-se no Quadro 10 que a maioria das empresas responderam alguma exigência futura ou exigências a mais do que conta na diretiva européia, o que retrata a preocupação dos europeus quanto a qualidade de sua carne bovina importada e o aumento da especificidade da carne bovina.

\begin{tabular}{|c|c|}
\hline Empresas & Respostas \\
\hline A & $\begin{array}{l}\text { Em relação a parte de garantia de qualidade e sanitária, as especificações } \\
\text { seguem as diretivas. O que muda muitas vezes são as especificações } \\
\text { comercias, como acréscimos da logomarca, data de produção, } \\
\text { documentação, etc. }\end{array}$ \\
\hline B & $\begin{array}{l}\text { A empresa argumentou que alguns exigem dados diferentes na rotulação do } \\
\text { produto }\end{array}$ \\
\hline $\mathrm{C}$ & $\begin{array}{l}\text { Rastreabilidade total (para o ano de 2005). Às vezes tem outras exigências } \\
\text { a mais do que consta na diretiva, mas isso só ocorre quando já aconteceu } \\
\text { algum problema do país importador em relação a um fornecedor. }\end{array}$ \\
\hline $\mathrm{D}$ & Fazer o controle de Material de risco para Encefalopatias (MRE). \\
\hline $\mathrm{E}$ & A empresa apenas respondeu que sim. \\
\hline $\mathrm{F}$ & - \\
\hline G & $\begin{array}{l}\text { A empresa disse que não obteve nenhuma exigência a mais dos países } \\
\text { europeus }\end{array}$ \\
\hline $\mathrm{H}$ & $\begin{array}{l}\text { Em relação às exigências a mais do que consta na diretiva, ocorre o } \\
\text { cumprimento de circulares, sendo que a última foi a circular } 463 \text {, e que no } \\
\text { momento não há novas exigências. }\end{array}$ \\
\hline I & $\begin{array}{l}\text { Talvez ISO 9000, alergênicos (substâncias que causam alergias ao } \\
\text { consumidor), relatórios de controle de organismo geneticamente } \\
\text { modificado. }\end{array}$ \\
\hline
\end{tabular}

Quadro 10 - Clientes europeus: exigências futuras e adicionais às existentes

Fonte: dados da pesquisa

- não respondeu 


\subsection{Relação com o fornecedor}

Esta seção se refere ao relacionamento das empresas com seus fornecedores de boi, em que se pretende verificar se a especificidade do ativo está alterando as formas de governança.

A Tabela 27 traz informações sobre a forma como o frigorífico adquire o boi.

Tabela 27. Forma de adquirir a matéria-prima boi

\begin{tabular}{lcc}
\hline & Freqüência & Percentagem \\
\hline Compra de boi antes de 1996) & 8 & 100,0 \\
Via compra no mercado & 0 & 0,0 \\
Via contrato & 0 & 0,0 \\
Outro modo & 8 & 100,0 \\
TOTAL & & \\
Compra de boi atualmente & 8 & 100,0 \\
Via compra no mercado & 0 & 0,0 \\
Via contrato & 0 & 0,0 \\
Outro modo & 8 & 100,0 \\
TOTAL & & \\
\hline
\end{tabular}

Fonte: dados da pesquisa

Nota-se que das 8 empresas que responderam esta questão, todas compram boi via mercado, tanto antes de 1996, como atualmente, quando se amplificaram as exigências quanto à segurança do alimento (devido principalmente à descoberta em 1996 da relação da EEB com a CJD em humanos). A compra é feita por um comprador próprio da empresa via mercado ou por telefone, em que neste apenas há uma ordem de compra, em que existem critérios de compra, tais como rastreabilidade, raça, peso, castração, ou seja, a descrição do animal é feita por telefone, portanto sendo préestabelecida. Dessa forma a negociação é transparente, em que há total confiabilidade e 
fidelidade entre fornecedores e empresas. As empresas pagam à vista, em que geralmente cobram um desconto de $4 \%$, ou para 30 dias sem desconto.

Uma empresa respondeu que possui um sistema de controle de abate on-line via Internet, onde os pecuaristas têm acesso a várias informações sobre os animais encaminhados ao abate, o que faz aumentar a confiança entre fornecedor de boi e frigorífico.

A questão central é como a empresa garante o fornecimento de carne com as características requeridas comprando via mercado, já que sob a ótica da ECT, esta não é a forma mais eficiente de se governar esta transação dado o aumento da especificidade do ativo.

A Tabela 28 mostra que $87,5 \%$ de 8 empresas, cria boi para fornecimento próprio, ou seja, se verticaliza para trás, e apenas $12,5 \%$ não cria boi, sendo que $66,7 \%$ de 6 empresas têm uma participação abaixo de 50\% no total fornecido à empresa, 16,7\% uma participação maior que 50\%, e $16,7 \%$ de $0 \%$ de participação. Quanto ao motivo dessa integração, apenas 5 empresas responderam, onde $60 \%$ destas responderam que se integram para terem maior controle da qualidade e da rastreabilidade do boi, retratando o aumento da especificidade do boi, $20 \%$ devido à garantia da oferta de boi na entressafra e $20 \%$ responderam ambos. Muitas destas empresas possuem fazendas em que criam novilho precoce e boi verde ${ }^{18}$.

${ }^{18}$ O boi orgânico é aquele criado em pasto sem agrotóxico e sem adubação química, tratado com medicamentos homeopáticos, ou seja, um boi ecologicamente correto. Já no caso do boi verde, apesar de também se valer da criação a pasto como nos sistemas agroecológicos, permite-se o uso de adubos sintéticos solúveis, de antibióticos e medicamentos alopáticos. 
Tabela 28. Criação de boi para fornecimento próprio

\begin{tabular}{lcc}
\hline & Freqüência & Percentagem \\
Fornecimento próprio & & 87,5 \\
\hline Sim & 7 & 12,5 \\
Não & 1 & 100,0 \\
Total & 8 & \\
& & \\
Por quê? & 3 & 60,0 \\
Controle da qualidade/rastreabilidade & 1 & 20,0 \\
Garantir a oferta de boi na entressafra & 1 & 20,0 \\
Ambos & 5 & 100,0 \\
Total & & \\
& & 16,7 \\
Participação & 1 & 0,0 \\
$>50 \%$ & 0 & 66,7 \\
$=50 \%$ & 4 & 16,7 \\
$0<\mathrm{X}<50 \%$ & 1 & 100,0 \\
$0 \%$ & 6 & \\
Total & & \\
\hline
\end{tabular}

Fonte: dados da pesquisa

Observa-se que os frigoríficos obtêm boi via compra no mercado bem como criando boi para fornecimento próprio. Dessa forma, prevalece uma estrutura de governança mista, regida tanto pelo mercado, que é caracterizado pelo estabelecimento de reputação entre o frigorífico e o pecuarista, como pela verticalização para trás dos frigoríficos. 


\begin{tabular}{|l|l|}
\hline Empresas & \multicolumn{1}{|c|}{ Respostas } \\
\hline A & $\begin{array}{l}\text { Nos estados dos quais a empresa compra bovinos (SP, GO e MG) a doença } \\
\text { está erradicada. }\end{array}$ \\
\hline B & - \\
\hline C & Não compra da região Sul. Uma medida é verificar o controle de vacinação. \\
\hline D & $\begin{array}{l}\text { A empresa disse que o controle na compra de boi é realizado através de GTA } \\
\text { (Guia de Trânsito do Animal), onde se tem a certificação que o animal foi } \\
\text { vacinado contra a doença. A empresa não se atingiu naquela época, pois não } \\
\text { compra gado daquele estado para o abate. A origem do gado abatido é do } \\
\text { circuito Centro Oeste, que é zona livre de febre aftosa desde final de 1999. }\end{array}$ \\
\hline E & $\begin{array}{l}\text { O controle sanitário é exercido pela Defesa (MAA) e que a empresa apenas } \\
\text { cumpre as exigências sanitárias (Atestado de vacina e GTA). }\end{array}$ \\
\hline F & $\begin{array}{l}\text { O principal fornecedor da empresa é uma cooperativa que reúne criadores } \\
\text { que têm a mesma qualidade, padrão e a constância de seus rebanhos. }\end{array}$ \\
\hline G & - \\
\hline H & - \\
\hline I & Controle de vacinação. \\
\hline
\end{tabular}

Quadro 11 - Medidas tomadas pela empresa quanto à febre aftosa

Fonte: dados da pesquisa

- não respondeu

O Quadro 11 mostra as medidas tomadas pelas empresas na compra de boi em relação à febre aftosa e como essa doença atingiu a compra de boi pelas empresas em 2000 devido ao foco no RS e Grã Bretanha. Nota-se que a maioria das medidas é a verificação do atestado de vacinação e do GTA (guia de trânsito animal para abate, venda ou transferência de bovinos), e os surtos dessa doença no RS em nada afetou a adoção de novos cuidados ao se realizar a compra. Porém algumas empresas vêm adotando a certificação Eurepgap ${ }^{19}$ (Eurep - Euro Retalien Produce Working Group/ Gap - Good Agricultural Practice) como forma de controle da qualidade nas fazendas. Ressalta-se que a febre aftosa é a das principal barreira sanitária da carne bovina brasileira, em que a atuação do MAPA é muito importante no combate e controle da doença em todo o país.

19 O Eurepgap tem sido criado por supermercados europeus para assegurar alimentos seguros e ambientalmente corretos. A adesão é voluntária, e a norma abrange todo o sistema produtivo, daí a certificação ser concedida à propriedade. 
Tabela 29. Número de fornecedores da empresa

\begin{tabular}{lcccc}
\hline Empresa & \multicolumn{4}{c}{$\mathrm{N}^{\mathbf{o}}$ de fornecedores da empresa } \\
& \multicolumn{2}{c}{ Mercado interno } & \multicolumn{2}{c}{ Mercado externo } \\
\hline & Rastreados & Não rastreados & Rastreados & Não rastreados \\
A & $0 \%$ & $100 \%$ & $100 \%$ & $0 \%$ \\
B & - & - & - & - \\
C & $100 \%$ & $0 \%$ & $100 \%$ & $0 \%$ \\
D & - & - & - & - \\
E & $70 \%$ & $30 \%$ & $100 \%$ & $0 \%$ \\
F & $80 \%$ & $20 \%$ & $100 \%$ & $0 \%$ \\
G & - & - & - & - \\
H & - & - & - & - \\
I & $95 \%$ & $5 \%$ & $100 \%$ & $0 \%$ \\
\hline
\end{tabular}

Fonte: dados da pesquisa

- não respondeu

Em relação ao número de fornecedores de boi ao mercado interno, apenas a empresa A possui 100\% de fornecedores não rastreados destinados ao mercado interno, enquanto que as demais empresas têm abaixo de $30 \%$ de fornecedores de boi não rastreados. Em relação ao mercado externo, todas as empresas possuem 100\% de fornecedores rastreados, pois se não forem é impossível exportar. Nota-se que mesmo a carne com destino ao mercado interno, há grande número de fornecedores de boi rastreados, o que mostra a preocupação da empresa quanto à qualidade do produto que fornece aos seus consumidores bem como o aumento da especificidade da carne bovina. 
Tabela 30. Compra de boi rastreado

\begin{tabular}{lcc}
\hline Modo & Freqüência & Percentagem \\
\hline Via contrato formal & 0 & 0,0 \\
Sem contrato & 7 & 100,0 \\
O fornecedor não aceita & 0 & 0,0 \\
Total & 7 & 100,0 \\
\hline
\end{tabular}

Fonte: dados da pesquisa

Como pode se observar na Tabela 30,100\% das empresas compram boi rastreado sem contrato e nenhuma respondeu que o fornecedor não aceita a realização de contratos.

Tabela 31. Incentivo dado pela empresa ao boi rastreado

\begin{tabular}{lll}
\hline Incentivo & Freqüência & Percentagem \\
\hline Preço & 6 & 85,7 \\
Outro & 1 & 14,3 \\
Total & 7 & 100,0 \\
\hline
\end{tabular}

Fonte: dados da pesquisa

No que se refere ao incentivo dado pela empresa na compra de boi rastreado, das 7 empresas que responderam, $85,7 \%$ destas dão como incentivo o preço, e apenas $14,3 \%$ dão outro tipo de incentivo, como o oferecimento de brincar os bois para o pecuarista. Porém, atualmente o estímulo econômico para rastrear é baixo, pois o prêmio é muito pequeno. 
Tabela 32. Freqüência de compra de boi

\begin{tabular}{lcc}
\hline & Freqüência & Percentagem \\
\hline Diariamente & 7 & 100,0 \\
Semanalmente & 0 & 0,0 \\
Mensalmente & 0 & 0,0 \\
Anualmente & 0 & 0,0 \\
Total & 7 & 100,0 \\
\hline
\end{tabular}

Fonte: dados da pesquisa

A Tabela 32 mostra que as empresas compram boi diariamente de seus fornecedores, ou seja, a compra de boi bem como sua negociação é um processo que se repete todos os dias.

Percebe-se no quadro 12 que na maior parte dos frigoríficos há uma manutenção de seus fornecedores todo ano, mas sempre acabam agregando novos fornecedores. Assim, essa constância de fornecedores possibilita a criação de uma relação de credibilidade entre pecuarista e frigorífico, que também explica a pouca incidência de contratos formais entre as partes.

\begin{tabular}{|l|l|}
\hline Empresas & \multicolumn{1}{|c|}{ Respostas } \\
\hline A & $\begin{array}{l}\text { A empresa respondeu que possui alguns parceiros, com os quais } \\
\text { trabalham todos os anos, porém sempre aparecem fornecedores novos. }\end{array}$ \\
\hline B & Algumas vezes, quando o mercado aquece muito, porém possui criação \\
\hline C & Há uma estabilidade. \\
\hline D & - \\
\hline E & $\begin{array}{l}\text { Basicamente os fornecedores são os mesmos, embora a todo ano se } \\
\text { agreguem novos fornecedores. }\end{array}$ \\
\hline F & Metade são os mesmos e a outra metade são variáveis. \\
\hline G & $\begin{array}{l}\text { A empresa possui uma gama de fornecedores onde compra o gado na } \\
\text { medida de suas possibilidades. }\end{array}$ \\
\hline H & - \\
\hline I & $\begin{array}{l}\text { Normalmente a empresa procura manter os mesmos fornecedores, mas } \\
\text { sempre acaba tendo variações. }\end{array}$ \\
\hline
\end{tabular}

Quadro 12 - Variação dos fornecedores de boi

Fonte: dados da pesquisa

- não respondeu 
No que se refere às incertezas das transações, percebe-se pela Tabela 33 que em relação ao aumento do preço do boi verificou-se que não há uma tendência clara, já que os graus de incerteza altos e baixos tiveram o mesmo número de repostas, além disso, algumas empresas operam no mercado futuro de boi gordo Quanto à falta de boi para compra, a maioria das empresas tem baixa incerteza, o que pode ser explicada pelo fato de algumas empresas confinarem o gado para garantir a oferta na entressafra. No que se refere à concorrência com outros frigoríficos na compra de boi, a maior parte dos frigoríficos possuem baixa incerteza, porém como todas as empresas competem com outros frigoríficos na aquisição de boi, elas utilizam estratégias como criação própria e forma de pagamento à vista, em que este beneficia a empresa pelo fato de pagar mais barato e de obter clientes fiéis.

Dessa forma, as incertezas quanto à matéria-prima boi relacionadas ao ambiente econômico são consideradas baixas pela maior parte dos frigoríficos.

Tabela 33. Incerteza quanto à matéria-prima boi

\begin{tabular}{|c|c|c|c|}
\hline & Grau & Freqüência & Percentagem \\
\hline \multirow{4}{*}{$\begin{array}{l}\text { Aumento no preço do } \\
\text { boi }\end{array}$} & 1 - baixo & 3 & 42,9 \\
\hline & 2 - médio & 1 & 14,3 \\
\hline & 3 - alto & 3 & 42,9 \\
\hline & Total & 7 & 100,0 \\
\hline \multirow{4}{*}{$\begin{array}{l}\text { Falta de boi para } \\
\text { compra }\end{array}$} & 1 - baixo & 4 & 57,1 \\
\hline & 2 - médio & 2 & 28,6 \\
\hline & 3 - alto & 1 & 14,3 \\
\hline & Total & 7 & 100,0 \\
\hline \multirow{4}{*}{$\begin{array}{l}\text { Concorrência com } \\
\text { outros frigoríficos na } \\
\text { compra de boi }\end{array}$} & 1 - baixo & 4 & 57,1 \\
\hline & 2 - médio & 3 & 42,9 \\
\hline & 3 - alto & 0 & 0,0 \\
\hline & Total & 7 & 100,0 \\
\hline
\end{tabular}

Fonte: dados da pesquisa 
Em relação ao comportamento dos fornecedores, das 7 empresas que responderam esta questão, todas afirmaram que têm fornecedores que cumprem o estabelecido. Além disso, 4 delas $(57,1 \%)$ disseram que também possuem fornecedores que não cumprem o combinado. Porém a participação dos fornecedores que cumprem o combinado no total de casos ocorridos na empresa é maior ou igual a $90 \%$, enquanto a participação nos casos ocorridos de problemas com o fornecedor é menor ou igual $10 \%$.

Observa-se que não há um relacionamento conflitante entre pecuaristas e frigoríficos neste subgrupo, pois este relacionamento é marcado pela fidelidade e pelo conhecimento das partes, o que pode explicar a não adoção de contratos formais. Deve ser salientado que esta característica não é comum a todo o mercado de carnes nacional, onde, ao contrário, existem diversos problemas de confiança entre as partes.

\subsection{Relação com o cliente interno}

Esta seção tem como objetivo verificar se houve mudanças na forma de governança entre as empresas e os clientes internos.

A Tabela 34 mostra que todas as 7 empresas têm como clientes internos os supermercado/hipermercado, $85,7 \%$ das empresas têm como clientes atacados, $85,7 \%$ das empresas têm como clientes as boutiques de carne e açougues, $57,1 \%$ lojas próprias da empresa e $42,9 \%$ outros clientes, tais como food service, distribuidores e instituições. 
Tabela 34. Clientes do mercado interno

\begin{tabular}{llll}
\hline Clientes & & Freqüência & Percentagem \\
\hline Supermercado/Hipermerca & 7 & & 100,0 \\
do & & & 85,7 \\
Boutiques de carne & 6 & 85,7 \\
Açougues & 6 & 100,0 \\
Atacado & 7 & 57,1 \\
Loja própria da empresa & 4 & 42,9 \\
Outro & 3 & \\
\hline
\end{tabular}

Fonte: dados da pesquisa

Conforme relato das empresas, a maioria vende sua maior parcela para os supermercados/hipermercados.

Em relação à realização de contratos do frigorífico com o cliente interno, observa-se que em $62,5 \%$ das 8 empresas não realizam contratos, o que evidencia a credibilidade do cliente à qualidade da carne ofertada pelo frigorífico bem como a fidelidade do cliente ao frigorífico na compra da carne. Por sua vez, 37,5\% dos frigoríficos realizam algum tipo de contrato com os clientes do mercado interno. Dentre estes, contratos de reciprocidade, que se resumem no pagamento de comissões pelos frigoríficos para que sua carne esteja presente nas gôndolas de hipermercados, contrato de parceria com determinados clientes, em que dão especificações para atender a qualidade (ficha técnica do produto), há contratos de volumes controlados por nota fiscal de recebimento, em que cada contrato possui um número devido às especificações do cliente. Uma empresa disse que realiza contratos desde antes de 1996 e outra disse que começou realizar em 2002.

A Tabela 35 mostra que a freqüência de vendas de carne diariamente é maior que a venda semanal, o que significa que há uma alta repetição do processo de venda. Este fato torna as relações mais estáveis e possibilita um maior conhecimento entre o cliente e o frigorífico. 
Tabela 35. Freqüência de venda ao cliente interno

\begin{tabular}{llclc}
\hline & \multicolumn{2}{c}{ Freqüência } & \multicolumn{2}{c}{ Percentagem } \\
& $\mathrm{d}$ & $\mathrm{S}$ & $\mathrm{d}$ & $\mathrm{s}$ \\
\hline $\begin{array}{l}\text { Supermercado/Hipermerca } \\
\text { do }\end{array}$ & 6 & 1 & 85,7 & 14,3 \\
Boutiques de carne & 4 & 2 & & \\
Açougues & 4 & 2 & 57,1 & 28,6 \\
Atacado & 4 & 3 & 57,1 & 28,6 \\
Loja própria da empresa & 3 & 1 & 57,1 & 42,9 \\
Outro & 1 & 1 & 42,9 & 14,3 \\
Total & 7 & 7 & 14,3 & 14,3 \\
\hline
\end{tabular}

Fonte: dados da pesquisa

$\mathrm{d}=$ diariamente

$\mathrm{s}=$ semanalmente

Observa-se no Quadro 13 que na maior parte dos frigoríficos há uma manutenção de seus clientes todo ano, mas sempre acabam agregando novos clientes. Assim, essa constância de venda para os mesmos clientes possibilita a criação de uma relação de confiabilidade entre frigoríficos e clientes internos.

\begin{tabular}{|l|l|}
\hline Empresas & \multicolumn{1}{|c|}{ Respostas } \\
\hline A & $\begin{array}{l}\text { A variação está na faixa de } 20 \%, \text { pois sempre há os estabelecimentos } \\
\text { que fecham ou deixam de comprar. }\end{array}$ \\
\hline B & A empresa está desenvolvendo vários clientes. \\
\hline C & Há uma estabilidade, mas há interesse em ter novos clientes. \\
\hline D & - \\
\hline E & $\begin{array}{l}\text { Basicamente os mesmos clientes, embora a todo ano se agreguem } \\
\text { novos. }\end{array}$ \\
\hline F & $60 \%$ mesmos clientes, $40 \%$ variam. \\
\hline G & A variação é mínima, pois a empresa tem estes clientes há anos. \\
\hline H & - \\
\hline I & Não varia muito, mas a empresa está aberta a novos clientes. \\
\hline
\end{tabular}

Quadro 13 - Variação dos clientes

Fonte: dados da pesquisa 
No que se refere às incertezas existentes nas transações de venda de carne entre os frigoríficos e seus clientes, a Tabela 36 mostra que das 7 empresas, 42,9\% possuem baixa incerteza quanto à queda de preço da carne de boi, $85,7 \%$ têm baixa incerteza quanto à variação na renda do consumidor interno, o que pode estar ligada ao fato desses frigoríficos terem como opção a exportação de sua carne, $42,9 \%$ baixa e $42,9 \%$ média incertezas quanto à concorrência com carne de frango e suína.

Tabela 36. Incerteza quanto à venda da carne ao cliente interno

\begin{tabular}{|c|c|c|c|}
\hline & Grau & Freqüência & Percentagem \\
\hline \multirow{4}{*}{$\begin{array}{l}\text { Queda no preço da carne } \\
\text { de boi }\end{array}$} & 1- baixo & 3 & 42,9 \\
\hline & 2 - médio & 2 & 28,6 \\
\hline & 3 - alto & 2 & 28,6 \\
\hline & Total & 7 & 100,0 \\
\hline \multirow{4}{*}{$\begin{array}{l}\text { Variação na renda do } \\
\text { consumidor }\end{array}$} & 1 - baixo & 6 & 85,7 \\
\hline & 2 - médio & 1 & 14,3 \\
\hline & 3 - alto & 0 & 0,0 \\
\hline & Total & 7 & 100,0 \\
\hline \multirow{4}{*}{$\begin{array}{l}\text { Concorrência com carne } \\
\text { de frango e suína }\end{array}$} & 1 - baixo & 3 & 42,9 \\
\hline & 2 - médio & 3 & 42,9 \\
\hline & 3 - alto & 1 & 14,3 \\
\hline & Total & 7 & 100,0 \\
\hline
\end{tabular}

Fonte: dados da pesquisa

Assim, observa-se que os frigoríficos consideram que as incertezas quanto à venda da carne bovina ao cliente interno relacionadas ao ambiente econômico são na maioria baixas.

Em relação ao comportamento do cliente interno, das 7 empresas que responderam esta questão, todas afirmaram que têm clientes que cumprem o estabelecido. Além disso, 5 delas $(71,4 \%)$ disseram que também possui clientes que não 
cumprem o combinado. Porém a participação dos clientes que cumprem o combinado no total de casos ocorridos na empresa é igual ou maior que $80 \%$, enquanto a participação nos casos ocorridos de problemas com o cliente é menor ou igual $20 \%$. \%. Portanto, não há um relacionamento conflitante entre o frigorífico e o mercado interno.

\subsection{Relação com o cliente europeu}

Os resultados desta seção procuram identificar aspectos das relações dos frigoríficos com os clientes europeus.

Quanto ao modo de exportação, os resultados da pesquisa indicam que $75 \%$ das 8 empresas exportam tanto via traders como diretamente, e apenas $25 \%$ das empresas exportam apenas diretamente, e nenhuma das empresas exportam só por traders.

No que se refere ao período em que os frigoríficos exportam para a UE e por que a escolha deste mercado, das 9 empresas pesquisadas, 2 já exportavam para a UE antes de 1996, e 4 começaram a exportar depois de 1996, e três empresas não responderam, e exportam para a UE por esta pagar preços melhores, porém, é a mais exigente quanto à qualidade da carne bovina.

Os tipos de carne exportados para a UE e a porcentagem estão na tabela 37.

Tabela 37. Tipo de carne exportada para a UE

\begin{tabular}{lcc}
\hline & Freqüência & Percentagem \\
\hline Só In natura & 6 & 75,0 \\
Só Industrializada & 0 & 0,0 \\
Ambas & 2 & 25,0 \\
Total & 8 & 100,0 \\
\hline
\end{tabular}

Fonte: dados da pesquisa 
Observa-se que $75 \%$ das 8 empresas só exportam carne in natura, enquanto que apenas $25 \%$ das empresa frigoríficas exportam tanto carne in natura como industrializada para a UE, (das empresas que exportam ambos os tipos de carne, a carne in natura tem uma participação maior na quantidade exportada do que a industrializada). Ressalta que os tipos de corte exportados para a UE são aqueles que possuem maior valor agregado, tais como filé mignon, contra filé, coxão mole entre outros.

Os principais clientes europeus dos frigoríficos estão relacionados na Tabela 38.

Tabela 38. Principais clientes europeus

\begin{tabular}{lcc}
\hline & Freqüência & Percentagem \\
\hline Rede de supermercados & 2 & 28,6 \\
Atacadistas & 6 & 85,7 \\
Empresas processadoras & 5 & 71,4 \\
Distribuidor & 6 & 85,7 \\
Outros & 1 & 14,3 \\
\hline
\end{tabular}

Fonte: dados da pesquisa

A Tabela 38 mostra que de 7 empresas frigoríficas, $28,6 \%$ têm como clientes europeus os supermercado/hipermercado, 85,7\% têm como clientes atacados, 71,4\% possui como clientes empresas processadoras, $85,7 \%$ das empresas têm como clientes distribuidores, e 14,3\% outros clientes europeus, tais como redes de fast food. Porém, para a maioria das empresas, os distribuidores possuem uma maior participação na clientela.

A Tabela 39 traz informações sobre as exigências serem ou não consideradas barreiras não tarifárias pelos frigoríficos. 
Tabela 39. Opinião da empresa frigorífica sobre as exigências européias

\begin{tabular}{lcc}
\hline & Freqüência & Percentagem \\
\hline Retratam preocupação dos consumidores & 8 & 100,0 \\
Retratam barreiras não-tarifárias & 3 & 37,5 \\
Precisam ser cumpridas para permanecer no & 8 & 100,0 \\
mercado europeu & & \\
\hline
\end{tabular}

Fonte: dados da pesquisa

Como pode notar na Tabela $39,100 \%$ das 8 empresas disseram que as exigências européias retratam a preocupação dos consumidores, pois retratam apenas a legislação deles, o que evidencia o aumento da especificidade da carne bovina. $\mathrm{Na}$ entrevista, as 3 empresas responderam que o nível de preocupação por parte do cliente europeu em relação à segurança do alimento é altíssima, sendo muito exigentes quanto à qualidade e a documentação em dia dos países dos quais importam carne bovina.

Das 8 empresas, $100 \%$ disseram que tais exigências precisam ser cumpridas para permanecer no mercado e apenas $37,5 \%$ disseram que retratam barreiras nãotarifárias, pois têm exigências de determinados clientes que não são pertinentes ou não têm fundamento técnico, tais como a exigência de animais abatidos com 30 meses (o que é difícil para o Brasil, pois os animais na maioria são criados a pasto) e de determinados procedimentos de controle de qualidade.

Uma das empresas relatou que disse ao seu cliente que sua exigência não tinha fundamento técnico, sendo que o cliente respondeu que se a exigência não fosse cumprida não haveria compra, ilustrando que os frigoríficos podem sofrer pressões dos seus clientes europeus.

Outra empresa argumentou que o Eurepgap é exigido pela pressão dos pecuaristas europeus que o possui, pois estes sabem que o nosso custo é menor na criação de boi, devido à utilização da criação a pasto, e, portanto, considerava que esta exigência era para elevar o custo de produto brasileiro. Relatou também que tem visitado 
frigoríficos europeus, e o controle de qualidade dos frigoríficos brasileiros são muito mais rigorosos que os deles.

As principais medidas adotadas pelas empresas frigoríficas para o atendimento das exigências são relatadas na Tabela 40.

Tabela 40. Principais medidas adotadas para atender a essas exigências

\begin{tabular}{lcc}
\hline & Freqüência & Percentagem \\
\hline Investir em P\&D & 6 & 66,7 \\
Contratar mão-de-obra especializada & 6 & 66,7 \\
Implantação de programas de qualidade & 9 & 100,0 \\
Assegurar-se de fontes de fornecimento da & 9 & 100,0 \\
matéria-prima boi & & 0,0 \\
Não adotou nenhuma medida & 0 & 11,1 \\
Outra & 1 & \\
\hline
\end{tabular}

Fonte: dados da pesquisa

Das nove empresas que participaram da pesquisa, 100\% implantaram programas de qualidade, $100 \%$ passaram a assegura-se das fontes de fornecimento de boi, 66,7\% investiram em P\&D, 66,7\% contrataram mão-de-obra especializada e 11,1\% adotaram outras medidas, o que mostra um aumento significativo da especificidade de ativos das empresas.

A Tabela 41 mostra as principais de mandas das empresas em relação ao setor público na solução das exigências européias. 
Tabela 41. Principais demandas em relação ao setor público

\begin{tabular}{lcc}
\hline & Freqüência & Percentagem \\
\hline Emissão de selos de qualidade & 2 & 33,3 \\
Linha de financiamento a taxas de juros & 2 & 33,3 \\
acessíveis & 3 & \\
Implantação e coordenação do SISBOV & 2 & 50,0 \\
Outros & 6 & 33,3 \\
Total & & 100,0 \\
\hline
\end{tabular}

Fonte: dados da pesquisa

De 6 empresas que responderam este item, 50\% consideram que o governo deve implantar e coordenar o SISBOV, 33,3\% demandam emissão de selos de qualidade, 33,3\% linhas de financiamento e taxas de juros acessíveis e 33,3\% responderam outras demandas, tais como acordos de livre comércio para quedas de barreiras e implementação de portarias. Dessa forma, para as indústrias, a participação do governo ainda é muito importante.

Em relação à realização de contratos, $100 \%$ de 8 empresas disseram que sempre realizaram contratos de exportação com seus clientes europeus, em que nestes contratos há as especificações dos produtos de cada cliente europeu, dessa forma, além de atender às exigências das legislações e normas do país, existem exigências dos clientes para atender necessidades específicas (peculiaridades do comprador).

Observa-se na Tabela 42 que $85,7 \%$ das 7 empresas vendem diariamente a seus clientes europeus, apenas 14,3\% vendem semanalmente. À medida que vão sendo honrados, novos contratos são celebrados, porém, respeitando-se as condições de mercado naquele momento. 
Tabela 42. Freqüência de venda aos clientes europeus

\begin{tabular}{lcc}
\hline & Freqüência & Percentagem \\
\hline Diariamente & 6 & 85,7 \\
Semanalmente & 1 & 14,3 \\
Mensalmente & 0 & 0,0 \\
Anualmente & 0 & 0,0 \\
Total & 7 & 100,0 \\
\hline
\end{tabular}

Fonte: dados da pesquisa

As incertezas existentes no mercado europeu estão relacionadas na Tabela 43.

Tabela 43. Incerteza quanto à venda da carne ao cliente europeu

\begin{tabular}{|c|c|c|c|}
\hline & Grau & Freqüência & Percentagem \\
\hline \multirow{4}{*}{$\begin{array}{l}\text { Queda brusca no preço da carne } \\
\text { bovina }\end{array}$} & 1 - baixo & 4 & 57,1 \\
\hline & 2- médio & 2 & 28,6 \\
\hline & 3 - alto & 1 & 14,3 \\
\hline & Total & 7 & 100,0 \\
\hline \multirow[t]{4}{*}{ Alteração no câmbio } & 1 - baixo & 2 & 28,6 \\
\hline & 2- médio & 5 & 71,4 \\
\hline & 3 - alto & 0 & 0,0 \\
\hline & Total & 7 & 100,0 \\
\hline \multirow{4}{*}{$\begin{array}{l}\text { Imposição } \\
\text { sanitárias }\end{array}$} & 1 - baixo & 1 & 14,3 \\
\hline & 2- médio & 3 & 42,9 \\
\hline & 3 - alto & 3 & 42,9 \\
\hline & Total & 7 & 100,0 \\
\hline \multirow[t]{4}{*}{ Outra } & 1 - baixo & 0 & 0,0 \\
\hline & 2- médio & 1 & 14,3 \\
\hline & 3 - alto & 0 & 0,0 \\
\hline & Total & 7 & 100,0 \\
\hline
\end{tabular}

Fonte: dados da pesquisa 
Nota-se na Tabela 43 que das 7 empresas 57,1,\% consideram baixa a incerteza relacionada a queda de preço da carne bovina, 71,4\% têm média incerteza quanto à variação no câmbio, pois nos contratos fixam-se preços em dólar, o que leva muitas empresas a operarem no mercado futuro; as incertezas quanto à imposição de barreiras sanitárias são consideradas médias 42,9\% das empresas e alta por outras $42,9 \%$; e 14,3\% tem incerteza média em relação à outras incertezas, como uma catástrofe sanitária.

Em relação ao comportamento do cliente europeu, das 7 empresas que responderam a questão, todas afirmaram que têm clientes que cumprem o combinado. Além disso, 2 delas $(28,6 \%)$ disseram que também possui clientes que não cumprem o combinado. Porém a participação dos clientes que cumprem o combinado no total de casos ocorridos na empresa é igual ou maior que $85 \%$, enquanto a participação nos casos ocorridos de problemas com o cliente é menor ou igual 15\%.

\subsection{Produção}

Apenas algumas empresas responderam as questões relacionadas ao abate, produção e exportação. Em relação ao abate, apenas 2 empresas demonstraram sua evolução, uma a partir de 1996 e outra a partir de 1999, em que para ambas foi crescente nos últimos anos.

Em relação à produção, exportação, e faturamento, 2 empresas demonstraram sua evolução, uma a partir de 2001 e outra a partir de 2003, em que para ambas todas estas variáveis tiveram um desempenho crescente.

Em relação às exportações para a UE, apenas uma empresa respondeu, cuja exportações aumentaram para este bloco. 


\section{CONCLUSÕES}

O Sistema Agroindustrial (SAG) da carne bovina brasileira possui um rebanho bovino de aproximadamente 185 milhões de cabeças, sendo o maior rebanho comercial do mundo, em que a grande maioria é criado à pasto. Em relação aos frigoríficos, existem aproximadamente 1000 unidades, em que destes apenas 351 possuem sistema de inspeção federal. Além disso, apenas uma pequena parcela, aproximadamente 67 empresas, está apta a destinar sua produção ao mercado externo, por possuírem uma estrutura produtiva e tecnológica compatível com o padrão internacional. Porém, o SAG da carne bovina é caracterizado por uma baixa coordenação, devido principalmente aos conflitos de interesses entre seus diferentes elos.

$\mathrm{O}$ aumento das exigências dos consumidores europeus quanto à segurança do alimento conduziram à mudanças no ambiente institucional e organizacional no Brasil, dado que a União Européia é o principal importador de carne bovina brasileira.

Dentre as mudanças no ambiente institucional nacional mais relevantes destacam-se a implementação da rastreabilidade aos produtos cárneos (SISBOV no Brasil), bem como os programas de qualidade relativos à análise de riscos e pontos críticos, como o HACCP.

Estas alterações induziram o setor de carne bovina nacional a se modernizar, através de investimentos tecnológicos, principalmente para atender determinados requisitos relativos à qualidade da carne. Como conseqüência, aumentou o grau da 
especificidade dos ativos empregados nessa atividade, o que implica numa maior dependência entre os agentes.

Apesar do aumento das exigências dos consumidores europeus terem alterado o ambiente institucional do bloco, com conseqüentes alterações no ambiente institucional brasileiro, verificou-se que estas pouco impactaram a forma de governança das transações do SAG da carne bovina nacional, pois tanto antes de 1996, ano em que se iniciam os aumentos das exigências externas, como atualmente, continua-se tendo relações via mercado entre frigoríficos exportadores com os pecuaristas e com os clientes internos.

Os resultados da pesquisa indicam que as empresas investiram intensivamente em programas de qualidade, para poder atender as exigências que constam nas diretivas da UE. Observou-se que além de cumprirem às exigências desse bloco, os frigoríficos atendem também requisitos específicos de determinados clientes europeus, o que evidencia o aumento da especificidade da carne bovina, bem como de todos os outros ativos envolvidos na sua produção. Dentre outras medidas, cita-se a contratação de mão-de-obra especializada e investimentos em P\&D.

Dessa forma, a adoção destes programas de qualidade exigiu investimentos específicos por parte das empresas para atender a determinados requisitos, e, portanto, as mesmas terão uma perda de renda se exportarem para países que não os exigem, bem como quando têm que escoar sua produção (ou tipos de cortes específicos) para o mercado interno.

É interessante observar que embora a maioria dos frigoríficos tenha um nível de rastreabilidade parcial, alguns declararam que já abatem quase que 100\% de animais totalmente rastreados, assim, logo terão um nível de rastreabilidade completa. Os frigoríficos embora reconheçam a dificuldade de se encontrar animais rastreados, não adotam estratégias no sentido de hierarquizar a transação via contratos com fornecedores. O único incentivo dado é o pagamento de um preço maior à carne 
rastreada, o que não garante a oferta de animais se houver a rivalidade de outro frigorífico. Ou seja, ou não se adota uma estrutura de governança eficiente ou não se compra um boi realmente rastreado dado o baixo enforcement existente no quesito rastreabilidade.

Conforme a Economia dos Custos de Transação, a adoção de contratos de fornecimento formais entre frigoríficos e produtores de boi seria uma forma de governança mais eficiente. Contudo, duas explicações plausíveis podem ser dadas sobre a estrutura de governança adotada.

A primeira, comentada anteriormente, se refere à falta de enforcement da rastreabilidade por parte da UE e do governo brasileiro. A rastreabilidade pode não estar sendo aplicada corretamente - segundo as normas do SISBOV - pelos pecuaristas, ou seja, o pecuarista pode estar vendendo um boi não rastreado como se fosse, o que conduz ao pequeno aumento da especificidade do ativo boi, e por isso, aumentando muito pouco os custos de transação, o que explica a não existência de contratos formais.

A segunda diz respeito ao comportamento confiável estabelecido entre pecuaristas e frigoríficos neste subgrupo, o que se aproxima da situação descrita por Williamson (1989) no Quadro 1. Notou-se que há uma constância dos mesmos fornecedores de boi para os frigoríficos, o que possibilita adquirirem conhecimento uns dos outros, reduzindo a incerteza; observou-se também que são mínimos os casos em que ocorre algum problema com o fornecedor em não cumprir o combinado entre as partes, o que permite a criação de reputação entre as partes, ou seja, que não ajam oportunisticamente, o que economiza custos de transação.

Adicionando a isso o fato da compra de boi ser realizada diariamente pelas empresas, ou seja, um processo que se repete todos os dias e que, portanto, reduz os custos de transação por diminuir os custos de coleta de informações, constatou-se a prevalência da fidelização entre o produtor de boi e o frigorífico, não havendo desconfiança entre eles, isto é, há um compromisso confiável entre as partes, que é suficiente para garantir o comportamento cooperativo entre elas. Ressalta-se também 
que as incertezas quanto à matéria-prima boi em relação ao ambiente econômico são consideradas na maioria baixas por parte dos frigoríficos.

Observou-se também que algumas empresas iniciaram um processo de verticalização da produção para trás, de modo a atender as exigências impostas pelos clientes europeus e para garantir a oferta na entressafra.

Quanto à relação do frigorífico com o cliente interno, observou-se que a maioria dos frigoríficos não realiza contratos, o que pode também ser explicado pelo comportamento confiável entre as partes. $\mathrm{O}$ fato de haver pouca variação dos clientes a cada ano (sendo que estes, na maioria dos casos, sempre cumpre o combinado entre as partes, o que permite a criação de reputação), e o fato da maioria das vendas serem realizadas diariamente, o que significa que tais fatos possibilitam baixa incerteza e baixa ação oportunística entre o frigorífico e os clientes internos, leva-os ao estabelecimento de um compromisso confiável. Ressalta-se também que as incertezas quanto à venda da carne bovina ao cliente interno relacionadas ao ambiente econômico são consideradas na maioria baixas. Também as exigências dos clientes internos são menores que as dos externos, reduzindo-se a especificidade do ativo.

Dessa forma, apesar da maioria dos frigoríficos participarem de Programas de Novilho Precoce ou Alianças Mercadológicas, em que ambos estimulam a adoção de estruturas de governança mais restritas, continuam ainda a ter relações via mercado com fornecedores de boi e clientes internos, mesmo com o processo de diferenciação da carne bovina.

No que se refere à relação do frigorífico com o cliente europeu, constatou-se que há realização de contratos, que sob a ótica da ECT, é a forma mais eficiente de se governar esta transação, devido ao alto grau da especificidade da carne bovina e dos demais ativos envolvidos na sua produção, bem como se constatou que as incertezas quanto à venda carne bovina ao cliente europeu relacionadas ao ambiente econômico são na maioria médias. 
No que diz respeito ao SISBOV, observou-se que problemas relacionados à sua implantação, que têm levado as organizações presentes no SAG a reivindicarem a alteração de determinadas regras, têm dificultado sua real adoção pelos pecuaristas.

Assim, na relação do frigorífico com o fornecedor de boi, coexistem duas formas básicas de comercialização: a utilização do mercado e a verticalização: houve uma evolução para a verticalização de parte da produção de boi pelas empresas, devido ao aumento da especificidade do ativo, mas pelo fato de haver baixo oportunismo entre as partes, criando reputação e fidelização desses agentes, e também pela dificuldade de enforcement da rastreabilidade do boi, continua-se utilizando do mesmo modo o mercado.

Quanto à relação dos frigoríficos com os clientes internos, rejeita-se a hipótese, o que pode ser explicado pela presença de baixo oportunismo entre as partes, fazendo com que adotem uma forma de governança - mercado - baseada também em compromissos confiáveis. Contudo, no que se refere às relações dos frigoríficos com o mercado europeu, não se rejeita a hipótese, sendo que o aumento da especificidade dos ativos os conduziu ao estabelecimento de contratos como forma de diminuir seus custos de transação.

Ressalta-se que os frigoríficos exportadores são apenas um subgrupo da indústria frigorífica, e que desta forma, o estabelecimento de um comportamento confiável entre frigoríficos e os fornecedores de boi e frigoríficos e clientes internos pode não ocorrer para o restante do mercado. 
ANEXOS 
ANEXO A - Códigos utilizados

\begin{tabular}{|c|c|}
\hline $\begin{array}{l}\text { Código } \\
\text { NCM }\end{array}$ & Descrição NCM \\
\hline 16025000 & $\begin{array}{l}\text { PREPARACOES ALIMENTICIAS E CONSERVAS,DE BOVINOS } \\
\text { CARCACAS E MEIAS CARCACAS DE BOVINO,FRESCAS OU }\end{array}$ \\
\hline 02011000 & REFRIGER \\
\hline 02012090 & $\begin{array}{l}\text { OUTRAS PECAS NAO DESOSSADAS DE BOVINO,FRESCAS OU } \\
\text { REFRIG }\end{array}$ \\
\hline & CARNES DESOSSADAS DE BOVINO,FRESCAS OU \\
\hline 02013000 & $\begin{array}{l}\text { REFRIGERADAS } \\
\text { QUARTOS DIANTEIROS NAO DESOSSADOS DE }\end{array}$ \\
\hline 02022010 & $\begin{array}{l}\text { BOVINO,CONGELADOS } \\
\text { QUARTOS TRASEIROS NAO DESOSSADOS DE }\end{array}$ \\
\hline 02022020 & BOVINO,CONGELADOS \\
\hline 02022090 & OUTRAS PECAS NAO DESOSSADAS DE BOVINO,CONGELADAS \\
\hline 02023000 & $\begin{array}{l}\text { CARNES DESOSSADAS DE BOVINO,CONGELADAS } \\
\text { MIUDEZAS COMESTIVEIS DE BOVINO,FRESCAS OU }\end{array}$ \\
\hline 02061000 & REFRIGERADAS \\
\hline 02062100 & LINGUAS DE BOVINO,CONGELADAS \\
\hline 02062200 & FIGADOS DE BOVINO,CONGELADOS \\
\hline 02062910 & RABOS DE BOVINO,CONGELADOS \\
\hline 02062990 & $\begin{array}{l}\text { OUTRAS MIUDEZAS COMESTIVEIS DE BOVINO,CONGELADAS } \\
\text { CARNES DE BOVINOS,SALGADAS/EM }\end{array}$ \\
\hline 02102000 & SALMOURA/SECAS/DEFUMADAS \\
\hline
\end{tabular}

Fonte: Brasil (2004d)

A Nomenclatura Comum do Mercosul (NCM) é composta de oito dígitos, sendo os seis primeiros formados pelo Sistema Harmonizado (capítulo, posição e subposição), e os dois últimos (item e subitem), criados de acordo com a definição estabelecida entre os países do Mercosul. A classificação das mercadorias na NCM regese pelas Regras Gerais para a Interpretação do Sistema Harmonizado (Brasil, 2004d). 
ANEXO B - Evolução histórica da regulamentação da cadeia bovina

\begin{tabular}{|c|c|c|}
\hline \begin{tabular}{|l|} 
Principais \\
Medidas \\
Institucionais
\end{tabular} & Data & Objetivo \\
\hline Lei $n^{\circ} 1.283$ & 18/Dez/1950 & $\begin{array}{l}\text { Estabelece o Regulamento da Inspeção } \\
\text { Industrial e Sanitária de Produto de Origem } \\
\text { Animal, por meio da fiscalização dos produtos } \\
\text { de origem animal, bem como dos } \\
\text { estabelecimentos para abate e preparação da } \\
\text { carne e transporte. }\end{array}$ \\
\hline \begin{tabular}{|l|} 
Decreto \\
$n^{\circ} 30.691$
\end{tabular} & 29/Mar/1952 & $\begin{array}{l}\text { Aprova o Regulamento da Inspeção Industrial e } \\
\text { Sanitária de Produtos de Origem Animal }\end{array}$ \\
\hline Lei $n^{\circ} 5.760$ & 03/Dez/1971 & $\begin{array}{l}\text { Criação da Lei de Federalização da Inspeção, de } \\
\text { forma progressiva todos os frigoríficos passam a } \\
\text { Ter fiscalização federal. }\end{array}$ \\
\hline Decreto $n^{\circ} 78.713$ & 11/Nov /1976 & $\begin{array}{l}\text { Os Estados, o Distrito Federal e os Territórios, } \\
\text { que pretendam celebrar convênios com a União, } \\
\text { para a realização dos serviços de inspeção } \\
\text { industrial e sanitária dos produtos de origem } \\
\text { animal, de que tratam as Leis no } 1.283 \text {, de } 18 \text { de } \\
\text { dezembro de } 1950,5.760 \text {, de } 3 \text { de dezembro de } \\
1971 \text { e respectivos regulamentos e a Lei no } 6.275 \\
\text { de } 1^{\circ} \text { de dezembro de } 1975 \text {, deverão dispor de } \\
\text { organismos próprios, em condições de exercer a } \\
\text { inspeção e fiscalização sobre as pequenas e } \\
\text { médias empresas que não se dediquem ao as a } \\
\text { comércio interestadual ou internacional. }\end{array}$ \\
\hline $\begin{array}{l}\text { Portaria SIPA } \\
n^{\circ} 5\end{array}$ & 08/Nov/1988 & $\begin{array}{l}\text { Estabelece normas para a Padronização de } \\
\text { Cortes de Carne Bovina }\end{array}$ \\
\hline $\begin{array}{l}\text { Portaria } \\
\text { Ministerial } \\
\mathrm{n}^{\mathrm{o}} 612\end{array}$ & 05/Out/1989 & $\begin{array}{l}\text { Estabelece normas para a Tipificação das } \\
\text { Carcaças de bovinos }\end{array}$ \\
\hline Lei n $^{0} 7.889$ & 23/Nov/1989 & $\begin{array}{l}\text { Passa a responsabilidade pela inspeção sanitária } \\
\text { até então exclusivamente da União, para Estados } \\
\text { e Municípios. }\end{array}$ \\
\hline $\begin{array}{l}\text { Portaria } \\
\text { Ministerial } \\
\mathrm{n}^{\mathbf{0} 2} 268\end{array}$ & 04/Maio/1995 & $\begin{array}{l}\text { Estabelece os Padrões de Qualidade do Novilho } \\
\text { Precoce }\end{array}$ \\
\hline $\begin{array}{l}\text { Portaria } \\
n^{\circ} 304, \text { MAARA }\end{array}$ & 22/Abr/1996 & $\begin{array}{l}\text { Estabelece que somente poderá ser feita a } \\
\text { entrega de carne de bovinos, com temperatura de } \\
\text { até } 7^{\circ} \mathrm{C} \text {, em cortes padronizados, devidamente } \\
\text { embalados e identificados, apresentando-se para } \\
\text { comercialização contendo as marcas e carimbos } \\
\text { oficiais com a rotulagem de identificação. }\end{array}$ \\
\hline
\end{tabular}


ANEXO B - Evolução histórica da regulamentação da cadeia bovina

\begin{tabular}{|c|c|c|}
\hline $\begin{array}{l}\text { Principais } \\
\text { Medidas } \\
\text { Institucionais }\end{array}$ & Data & Objetivo \\
\hline $\begin{array}{l}\text { Portaria } \\
n^{\circ} 89 \text { da DAS do } \\
\text { MAARA }\end{array}$ & 15/Jul/1996 & $\begin{array}{l}\text { Institui o Programa de Distribuição de Carnes } \\
\text { Bovina e Bubalina ao comércio varejista, } \\
\text { previamente, embalada e identificada, visando à } \\
\text { implantação da Portaria } 304 \text {. A identificação } \\
\text { deve conter informações de interesse ao } \\
\text { consumidor, previstas na legislação, como a } \\
\text { espécie, o sexo do animal e data de abate. }\end{array}$ \\
\hline $\begin{array}{l}\text { Portaria } \\
n^{\circ} 90 \text { da DAS, do } \\
\text { MAARA }\end{array}$ & 15/Jul/1996 & $\begin{array}{l}\text { Institui a obrigatoriedade da fixação de } \\
\text { etiquetas-lacre de segurança nos cortes de } \\
\text { bovinos, bubalinos e suíno, independentes da } \\
\text { aplicação de carimbos oficiais. }\end{array}$ \\
\hline${\text { Portaria } \mathrm{n}^{\circ} 36}$ & $30 / \mathrm{Abr} / 1997$ & $\begin{array}{l}\text { Ampliação dos Estados e municípios que devem } \\
\text { adaptar-se à Portaria } 304 \text { - São } 180 \text { municípios } \\
\text { dos Estados do RS, SC, PR, SP, RJ, ES, BA, SE, } \\
\text { GO, MS, MT, DF. Além disso, a implantação de } \\
\text { grupos técnicos para a análise e futura inclusão } \\
\text { de municípios com mais de } 200 \text { mil habitantes } \\
\text { no Programa de Distribuição de Carnes ao } \\
\text { Comércio Varejista. }\end{array}$ \\
\hline $\begin{array}{l}\text { Decreto } \\
n^{\circ} 2.244\end{array}$ & 04/Jun/1997 & $\begin{array}{l}\text { Altera dispositivos do Decreto } \mathrm{n}^{\circ} 30.691 \text {. Em } \\
\text { função da adesão do Brasil ao Mercosul, passa a } \\
\text { ser permitido o sacrifício de animais apenas por } \\
\text { métodos humanitários, utilizando-se de prévia } \\
\text { insensibilização baseadas em princípios } \\
\text { científicos, seguida de imediata sangria. }\end{array}$ \\
\hline $\begin{array}{l}\text { Portaria } \\
n^{0} 290\end{array}$ & 16/Jul/1997 & $\begin{array}{l}\text { Proibir, em todo o Território Nacional, o uso de } \\
\text { qualquer fonte de proteína de ruminantes na } \\
\text { alimentação de ruminantes. }\end{array}$ \\
\hline $\begin{array}{l}\text { Portaria } \\
n^{\circ} 142\end{array}$ & 23/Dez/1997 & $\begin{array}{l}\text { Descreve sobre o Programa de Distribuição de } \\
\text { carnes bovina e bubalinas ao comércio varejista }\end{array}$ \\
\hline $\begin{array}{l}\text { Portaria } \\
n^{\circ} 46\end{array}$ & 10/Fev/1998 & $\begin{array}{l}\text { Instituir o sistema de análise de perigos e pontos } \\
\text { críticos de controle - APPCC a ser implantado, } \\
\text { gradativamente, nas indústrias de produtos de } \\
\text { origem animal sob o regime do serviço de } \\
\text { inspeção federal - SIF, de acordo com o manual } \\
\text { genérico de procedimentos. }\end{array}$ \\
\hline
\end{tabular}


ANEXO B - Evolução histórica da regulamentação da cadeia bovina

\begin{tabular}{|c|c|c|}
\hline \begin{tabular}{|l|} 
Principais \\
Medidas \\
Institucionais
\end{tabular} & Data & Objetivo \\
\hline $\begin{array}{l}\text { Portaria } \\
n^{\circ} 25\end{array}$ & 24/Mar/1998 & $\begin{array}{l}\text { Institui os Comitês Técnicos, com a finalidade } \\
\text { de coordenar e orientar a execução das } \\
\text { atividades de implantação do Sistema de Análise } \\
\text { de Perigos e Pontos Críticos de Controle - } \\
\text { HACCP - nas indústrias de produtos de origem } \\
\text { animal, sob o regime do SIF. }\end{array}$ \\
\hline Portaria $\mathrm{n}^{\circ} 214$ & 20/Maio/1998 & $\begin{array}{l}\text { A entrada no país de bovinos destinados à cria, } \\
\text { recria e engorda, para posterior abate somente } \\
\text { será permitida aos animais identificados } \\
\text { individualmente por um brinco plástico } \\
\text { numerado, no modelo aprovado pela Secretaria } \\
\text { de Defesa Agropecuária deste Ministério. }\end{array}$ \\
\hline $\begin{array}{l}\text { Portaria } \\
n^{\circ} 145\end{array}$ & $\begin{array}{l}\text { Editada em } \\
\text { Setembro de } \\
\text { 1998, porém em } \\
\text { vigor desde } \\
\text { 04/Jan/1999 }\end{array}$ & $\begin{array}{l}\text { A Portaria prevê a venda de carne desossada ou } \\
\text { cortada com osso dos frigoríficos ou } \\
\text { distribuidores para o setor. A venda para o setor } \\
\text { varejista deverá ser em caixas ou containeres } \\
\text { apropriados. Os demais municípios possuem até } \\
\text { agosto do ano } 2000 \text { para se enquadrarem. }\end{array}$ \\
\hline Lei 9.712 & 1998 & $\begin{array}{l}\text { Estabelece regras para a formação das Agências } \\
\text { Executivas. }\end{array}$ \\
\hline 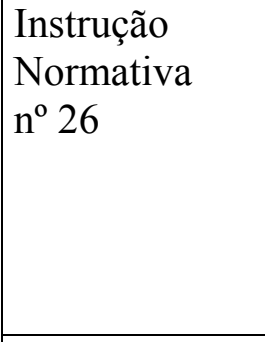 & 12/Jun/2001 & $\begin{array}{l}\text { Aprovar o Manual de } \\
\text { Operacionais da Vigilância } \\
\text { Internacionalimentos a ser utilizado na fiscalização e } \\
\text { inspeção do trânsito internacional de produtos } \\
\text { agropecuários, nos aeroportos internacionais, } \\
\text { portos estruturados, postos de fronteira e } \\
\text { aduanas especiais. }\end{array}$ \\
\hline $\begin{array}{l}\text { Instrução } \\
\text { Normativa } \\
n^{\circ} 1\end{array}$ & 09/Jan/2002 & $\begin{array}{l}\text { Instituir o Sistema Brasileiro de Identificação e } \\
\text { Certificação de Origem Bovina e Bubalina - } \\
\text { SISBOV. }\end{array}$ \\
\hline $\begin{array}{l}\text { Instrução } \\
\text { Normativa } \\
n^{\circ} 18\end{array}$ & $15 / \mathrm{Fev} / 2002$ & $\begin{array}{l}\text { Aprova as Normas a serem adotadas, visando } \\
\text { incrementar a vigilância pidemiológica para } \\
\text { detecção de Encefalopatias Espongiformes } \\
\text { Transmissíveis - EET - em ruminantes. }\end{array}$ \\
\hline $\begin{array}{l}\text { Instrução } \\
\text { normativa } n^{\circ} 1\end{array}$ & $28 / \mathrm{Fev} / 2003$ & $\begin{array}{l}\text { Aprovar o Regulamento Técnico sobre as } \\
\text { Condições Higiênico-Sanitárias e de Boas } \\
\text { Práticas de Fabricação para Estabelecimentos } \\
\text { Fabricantes e Industrializadores de Alimentos } \\
\text { para Animais e o Roteiro de Inspeção. }\end{array}$ \\
\hline
\end{tabular}


ANEXO B - Evolução histórica da regulamentação da cadeia bovina

\begin{tabular}{|c|c|c|}
\hline \begin{tabular}{|l|} 
Principais \\
Medidas \\
Institucionais \\
\end{tabular} & Data & Objetivo \\
\hline $\begin{array}{l}\text { Portaria } \\
n^{0} 7\end{array}$ & $02 / \mathrm{Abr} / 2003$ & $\begin{array}{l}\text { Aprova os procedimentos operacionais relativos } \\
\text { à habilitação, auditorias e supervisões em } \\
\text { estabelecimentos produtores de carnes e } \\
\text { derivados e de ovos e derivados habilitados ao } \\
\text { comércio internacional, em conformidade com } \\
\text { os anexos. }\end{array}$ \\
\hline Resolução 10 & 28/Mai/2003 & $\begin{array}{l}\text { Institui o Programa Genérico de } \\
\text { PROCEDIMENTOS - PADRÃO DE HIGIENE } \\
\text { OPERACIONAL - PPHO, a ser utilizado nos } \\
\text { Estabelecimentos de Leite e Derivados que } \\
\text { funcionam sob o regime de Inspeção Federal, } \\
\text { como etapa preliminar essencial dos Programas } \\
\text { de Segurança Alimentar do tipo APPCC } \\
\text { (Análise de Perigos e Pontos Críticos de } \\
\text { Controle). }\end{array}$ \\
\hline $\begin{array}{l}\text { Instrução } \\
\text { Normativa } \\
n^{0} 33\end{array}$ & 02/Jun/2003 & $\begin{array}{l}\text { Aprovar os Anexos desta Instrução Normativa, } \\
\text { que estabelecem o funcionamento do Serviço de } \\
\text { Vigilância Agropecuária Internacional junto às } \\
\text { fronteiras internacionais (portos, aeroportos, } \\
\text { postos de fronteira e aduanas especiais) e do } \\
\text { Serviço de Inspeção Federal - SIF junto aos } \\
\text { estabelecimentos habilitados ao comércio } \\
\text { internacional, com vistas ao controle das } \\
\text { exportações de produtos de origem animal. }\end{array}$ \\
\hline $\begin{array}{l}\text { Portaria } \\
n^{\circ} 134\end{array}$ & 14/Jul/2003 & $\begin{array}{l}\text { Autoriza o ingresso no Estado de Santa Catarina } \\
\text { de carne bovina fresca, com osso, oriunda dos } \\
\text { estados integrantes da zona livre de febre aftosa } \\
\text { com vacinação. }\end{array}$ \\
\hline $\begin{array}{l}\text { Instrução } \\
\text { Normativa } \\
n^{0} 83\end{array}$ & 21/Nov/2003 & $\begin{array}{l}\text { Regulamentos Técnicos de Identidade e } \\
\text { Qualidade de Carne Bovina em Conserva } \\
\text { (Corned Beef) e Carne Moída de Bovino. }\end{array}$ \\
\hline $\begin{array}{l}\text { Instrução } \\
\text { Normativa } \\
n^{\circ} 8\end{array}$ & 26/Mar/2004 & $\begin{array}{l}\text { Proíbe em todo o território nacional a produção, } \\
\text { a comercialização e a utilização de produtos } \\
\text { destinados à alimentação de ruminantes que } \\
\text { contenham em sua composição proteínas e } \\
\text { gorduras de origem animal. }\end{array}$ \\
\hline
\end{tabular}


ANEXO B - Evolução histórica da regulamentação da cadeia bovina

\begin{tabular}{|c|c|c|}
\hline \begin{tabular}{|l|} 
Principais \\
Medidas \\
Institucionais
\end{tabular} & Data & Objetivo \\
\hline $\begin{array}{l}\text { Instrução } \\
\text { Normativa } \\
n^{0} 21\end{array}$ & 02/Abr/2004 & $\begin{array}{l}\text { Aprovar as normas operacionais do sistema } \\
\text { brasileiro de identificação e certificação de } \\
\text { origem bovina e bubalina - SISBOV, e } \\
\text { respectivos anexos. Através desta, realizar-se-á } \\
\text { auditoria nas propriedades, nos frigoríficos, nas } \\
\text { certificadoras, na agroindústria e no fabricante } \\
\text { de elementos de identificação atuando sob o } \\
\text { enfoque da responsabilidade de todos os } \\
\text { envolvidos na cadeia. Torna-se também } \\
\text { obrigatório informar o número do cadastro de } \\
\text { pessoa física ou jurídica do proprietário, o } \\
\text { número do imóvel junto à Receita Federal e o } \\
\text { número de animais que o pecuarista pretende } \\
\text { certificar. }\end{array}$ \\
\hline $\begin{array}{l}\text { Instrução } \\
\text { Normativa } \\
n^{\circ} 9\end{array}$ & 04/Mai/2004 & $\begin{array}{l}\text { Aprovar o Sistema Brasileiro de Classificação de } \\
\text { Carcaças de Bovinos, em todo o território } \\
\text { nacional, e a classificação dos bovinos abatidos } \\
\text { nos estabelecimentos sob o controle do Serviço } \\
\text { de Inspeção Federal (SIF). }\end{array}$ \\
\hline $\begin{array}{l}\text { Instrução } \\
\text { Normativa } \\
n^{0} 77\end{array}$ & 29/Out/2004 & $\begin{array}{l}\text { Apenas os animais cuja carne é destinada à } \\
\text { exportação precisam estar cadastrados no } \\
\text { Sistema Brasileiro de Identificação e } \\
\text { Certificação de Origem Bovina e Bubalina } \\
\text { (Sisbov). O registro deve ser feito até } 40 \text { dias } \\
\text { antes do gado e dos búfalos serem abatidos nos } \\
\text { frigoríficos credenciados para atender o mercado } \\
\text { externo. }\end{array}$ \\
\hline
\end{tabular}

Fonte: IEL et al. (2000) e Brasil (2004b) 


\section{REFERÊNCIAS BIBLIOGRÁFICAS}

AGUIAR, D.R.D.; SILVA, A.L. Changes in beef consumption and retailing competitiveness in Brazil: a rapid appraisal. Agribusiness, v.18, n.2, p.145-161, 2002.

ASSOCIAÇÃO BRASILEIRA DA INDÚSTRIA EXPORTADORA DE CARNE (ABIEC). Entidade. http://www.abiec.org.br/abiec/missão.php (18 mar. 2004)

BÁNKUTI, F.I. Entraves e incentivos ao abate clandestino de bovinos no Brasil. São Carlos, 2002. 159p. Dissertação (Mestrado) - Centro de Ciências Exatas e de Tecnologia, Universidade Federal de São Carlos.

BÁNKUTI, F.I.; AZEVEDO, P.F. Abates clandestinos de bovinos: uma análise das características do ambiente institucional. http://www.fanorpi.com.br/web/exercicio2003/Abates\%20clandestnos.pdf (23 fev. 2004a)

BÁNKUTI, F.I.; AZEVEDO, P.F. Na clandestinidade: o mercado informal de carne bovina. http://www.iea.sp.gov.br/out/arquivo.php?ano=2000 (23 fev. 2004b)

BARCELlOS, M.D. de; FERREIRA, G.C. Direito do consumidor. Agroanalysis, v.23, n.4, p.27-30, jun. 2003.

BARROS, A.J.S.; LEHFELD, N.A.S. Fundamentos de metodologia científica: um guia para a iniciação científica. 2.ed. São Paulo: Makron Books, 2000. 84p. 
BEEFPOINT. Algumas novidades e muitos desafios aguardam 2004 na cadeia de carne bovina brasileira. http://www.beefpoint.com.br/bn/especiais/ (21 mar. 2004b)

BEEFPOINT. Panorama mundial do setor de carnes em 2003. http://www.beefpoint.com.br/bn/especiais/ (21 mar. 2004a)

BRASIL. Ministério da Agricultura, Pecuária e Abastecimento (MAPA). Defesa Agropecuária. http:www.defesaagropecuária.gov.br/sda/index.htm (01 abr. 2004a)

BRASIL. Ministério da Agricultura, Pecuária e Abastecimento (MAPA). Legislação. http://www.agricultura.gov.br/ (01 abr. 2004b)

BRASIL. Ministério da Agricultura, Pecuária e Abastecimento (MAPA). Estatísticas. http://www.agricultura.gov.br/ (18 mar. 2004c)

BRASIL. Ministério do Desenvolvimento, Indústria e Comércio Exterior (MDIC). Sistema Alice. http://www.agricultura.gov.br (18 mar. 2004d)

BRASIL. Secretaria do Comércio Exterior (SECEX). Barreiras externas às exportações brasileiras. Brasília, 2001. http://www.mdic.gov.br (20 fev. 2004)

CAVALCANTI, M.R. Acesso a mercados internacionais: sanidade é o primeiro passo. http://www.beefpoint.com.br/bn/editorial/ (23 mar. 2004a)

CAVALCANTI, M.R. Perspectivas e oportunidades para a cadeia de carne bovina brasileira em 2004. http://www.beefpoint.com.br/bn/editorial/ (23 mar. 2004b)

CENTRO DE ESTUDOS AVANÇADOS EM ECONOMIA APLICADA (CEPEA). Indicadores de preços. http://www.cepea.esalq.usp.br (27 set. 2004) 
COSTA, T.V.A.M. Integração regional e seus efeitos sobre as exportações brasileiras de carne avícola. Porto Alegre, 1999. 131p. Dissertação (Mestrado) - Faculdade de Ciências Econômicas, Universidade Federal do Rio Grande do Sul. http://www.ufrgs.br/pgdr/dissertacoes/ecorural/mecorural_costa_n203.pdf (31 jul. 2004)

DOIS anos sem febre aftosa. Agroanalisys, v.23, n.10, p.21, jan. 2004.

DÖRR, A.C. O posicionamento da indústria avícola frente às restrições do mercado consumidor europeu. São Paulo, 2003. 145p. Dissertação (Mestrado) - Escola Superior de Agricultura "Luiz de Queiroz”, Universidade de São Paulo.

ESTADOS UNIDOS. Department of Agriculture (USDA). Data and statistics. http://www.usda .gov/dlp/countrypages/brbfsit.pdf (04 May 2004)

EUROPA. Comissão Européia. Atividades da UE. http://www.europa.eu.int (05 May 2004b)

EUROPA. Comissão Européia. Legislação. http://www.europa.eu.int (05 May 2004a)

FAO. Statistical databases. http://www.fao.org.br (20 Mar. 2004)

FARINA, E.M.M.Q.; AZEVEDO, P.F. de; SAES, M.S.M. Competitividade: mercado, estado e organizações. São Paulo: Editora Singular, 1997. 286p.

FARINA, E.M.M.Q.; ZYLBERSZTAJN, D. Competitividade e organização das cadeias agroindustriais. San Jose: Instituto Interamericano de Cooperação para a Agricultura (IICA), 1994. 63p.

FAVERET FILHO, P.; PAULA, S.R.L. de. Cadeia da carne bovina: o novo ambiente competitivo. BNDES Setorial, n.6, p.97-116, set 1997.

FNP Consultoria \& Agroinformativos. Anualpec: anuário da pecuária brasileira. São Paulo, 2003. p.80: Pecuária de corte. 
FRANCO, M. Desafios internos. Agroanalysis, v.23, n.4, p.16-20, jun. 2003.

FUTURO promissor para a pecuária. DBO Rural, n.280, p.12, mar. 2004e.

GIL, A.C. Métodos e técnicas de pesquisa social. 5.ed. São Paulo: Editora Atlas, 1999. $195 p$.

IBA, S.K.; BRABET, C.; OLIVEIRA, I.J. de; PALLET, D. Um panorama da rastreabilidade dos produtos agropecuários do Brasil destinados à exportação: carnes, soja e frutas. São Paulo, nov. 2003. http://www.cirad.org.br/prosper (21 maio 2004)

INSTITUTO BRASILEIRO DE GEOGRAFIA E ESTATÍSTICA (IBGE). Sidra. http://www.ibge.gov.br (25 mar. 2004)

INSTITUTO EUVALDO LODI (IEL); CONFEDERAÇÃO NACIONAL DA AGRICULTURA (CNA); SEBRAE NACIONAL. Estudo sobre a eficiência econômica e competitividade da cadeia agroindustrial da pecuária de corte no Brasil. Brasília: IEL, 2000. http://www.cna.org.br/cadeias/cadeias_pecuarial.htm (05 fev. 2004)

INSTITUTO PARANAENSE DE DESENVOLVIMENTO ECONÔMICO E SOCIAL (IPARDES); INSTITUO BRASILEIRO DA QUALIDADE E PRODUTIVIDADE (IBPQ); UNIVERSIDADE FEDERAL DE SÃO CARLOS. Grupos de Estudos e Pesquisas Agroindustriais. Análise da competitividade da cadeia agroindustrial da carne bovina no estado do Paraná. Curitiba: IPARDES, 2002. http://www.pr.gov.br/ipardes/publicacoes/cadeias/publicacoes_cadeias.htm (05 fev. 2004)

JANK, M.S. Competitividade do agribusiness brasileiro: discussão teórica e evidências no sistema de carnes. São Paulo, 1996. 195p. Tese (Doutorado) - Faculdade de Economia, Administração e Contabilidade, Universidade de São Paulo. 
MACEDO, L.O.B. Dinâmicas evolucionárias e coordenação produtiva na bovinocultura de corte brasileira. Informações Econômicas, v.32, n.8, p.25-29, ago. 2002.

MIRANDA, S.H.G. de. Quantificação dos efeitos das barreiras não-tarifárias sobre as exportações brasileiras de carne bovina. São Paulo, 2001. 200p. Tese (Doutorado) Escola Superior de Agricultura “Luiz de Queiroz", Universidade de São Paulo.

MIRANDA, S.H.G. de; MOTTA, M.A.S.B. Exportação de carnes bovina brasileira: evolução por tipo e destino. Recife, mar. 2001. http://cepea.esalq.usp.br (20 maio 2004)

MORAES, M.A.F.D. de (Coord.). Estudo da competitividade de cadeias integradas no Brasil: impactos das zonas de livre comércio. Campinas: Unicamp, Instituto de Economia, Núcleo de Economia Industrial e da Tecnologia, dez. 2002. 122p.

NEVES, M.F.; MACHADO, C.P.; CARVALHO, D.T.; CASTRO, L.T. Redes agroalimentares \& marketing da carne bovina em 2010. Preços Agrícolas, v.15, n.171, p.7-18, jan./fev. 2001.

NORTH, D. Custos de transação, instituições e desempenho econômico. Rio de Janeiro: Instituto Liberal, 1994. 38p.

NORTH, D.C. The new institutional economics and development. St. Louis: Washington University, Economics Department, 1993. 11p. (Working paper) http://www.econwpa.wustl.edu.80/eps/eh/papers/9309/9309002.pdf (21 Jan. 2004)

OLIVEIRA NETO, O.J. de. Clusters: o novo ambiente competitivo. http://www.beefpoint.com.br/bn/espaçoaberto/ (22 maio 2004)

PECUARISTA de corte tem queda na renda. DBO Rural, n.280, p.24, mar. 2004c.

PIGATTO, G.; SILVA, A.L. da.; SOUZA FILHO, H.M. de. Alianças mercadológicas: a busca da coordenação na cadeia de gado de corte brasileira. http://www.gepai.dep.ufscar.br/gepai16.pdf (03 fev. 2004) 
PINEDA, N. Rastreabilidade: uma necessidade do mundo globalizado. http://www.beefpoint.com.br/bn/especiais/ (23 mar. 2004)

PITOMBO, L.H. Produção avança, mas a fatura cai. DBO Rural, n.280, p.16, mar. 2004.

POLÍTICAS e doenças afetam mercado mundial. DBO Rural, n.280, p.32, mar. 2004a.

RAMOS, M.H.F. Consumidor quer garantias da cadeia. DBO Rural, n.280, p.16, mar. 2004.

SANDRONI, P. Novíssimo dicionário de economia. São Paulo: Editora Best Seller, 1999. $847 \mathrm{p}$.

SIFFERT FILHO, N.; FAVERET FILHO, P. O sistema agroindustrial de carnes: competitividade e estruturas de governança. Thttp://www.bndes.gov.br/conhecimento/revista/rev1012.pdf (20T dez. 2003)

SIMÃO, G. Exportação de genética revoluciona o zebu. DBO Rural, n.280, p.46, mar. 2004.

SINDICATO DAS INDÚSTRIAS DE FRIO DO ESTADO DE SÃO PAULO (SINDIFRIO). Histórico. http://brazilianbeef.org.br/sindifrios/ (01 abr. 2004)

SISTEMA BRASILEIRO DE IDENTIFICAÇÃO DE ORIGEM BOVINA E BUBALINA (SISBOV). Sisbov e normativa. http://www. sisbov.com.br (06 mar. 2004)

SOUZA, J.P. de; PEREIRA, L.B.; SANTANA, E.A. de. Estratégias competitivas da cadeia agroindustrial de carnes no Brasil: percepções do distribuidor. http://www.fanorpi.com.br (02 mar. 2004) 
SPERS, E.E. Segurança do alimento. In: ZYLBERSZTAJN, D.; SCARE, R.F. (Org.). Gestão da qualidade no agrobusiness: estudos de caso. São Paulo: Atlas, 2003. cap.5, p.60-73.

TAVARES, E. Controle sanitário avança, mas é preciso muito mais. DBO Rural, n.280, p.104, mar. 2004.

TORRES JÚNIOR, A.M. Política cambial e influência na formação de preços de arroba bovina. http://www.beefpoint.com.br/bn/conjuntura/ (23 mar. 2004)

TROCA de insumos mostra decréscimo. DBO Rural, n.280, p.27, mar. 2004d.

VACAS puxam crescimento da produção. DBO Rural, n.280, p.18, mar. 2004b.

VINHOLIS, M.M.B. Uma análise da aliança mercadológica da carne bovina baseada nos conceitos da economia dos custos de transação. http://www.fearp.usp.br/egna/Por/ano1999.htm (03 fev. 2004)

VINHOLIS, M.M.B; AZEVEDO, P.F. Efeitos da rastreabilidade no sistema agroindustrial da carne bovina brasileira (compact disc). In: CONGRESSO BRASILEIRO DE ECONOMIA E SOCIOLOGIA RURAL, 39., Rio de Janeiro, 2000. Anais. Brasília: SOBER, 2000.

WILLIAMSON, O.E. Las instituciones económicas del capitalismo. México: Fondo de Cultura Económica, 1989. 435p.

YASSU, F. Brasil assume liderança mundial. DBO Rural, n.280, p.30, mar. 2004.

ZYLBERSTAJN, D. Estruturas de governança e coordenação do agribusiness: uma aplicação da nova economia das instituições. São Paulo, 1995. 241p. Tese (LivreDocência) - Faculdade de Economia, Administração e Contabilidade, Universidade de São Paulo. 
ZYLBERSZTAJN, D. Economia da organizações. http://www.projetoe.org.br/vteams/ tele_01/ leitura_01.html (06 mar. 2004) 
APÊNDICES 


\section{APÊNDICE 1 - Questionário}

\section{I - Características Gerais}

1. Nome da empresa e data de fundação

2. Qual mercado atendido por sua empresa?

\begin{tabular}{|l|l|}
\hline \multicolumn{1}{|c|}{ Mercado } & Participação (\%) na produção \\
\hline ( ) Mercado Interno & \\
\hline ( ) Mercado Externo & \\
\hline
\end{tabular}

3.Quais seus clientes internacionais?

\begin{tabular}{|l|l|l|}
\hline \multicolumn{1}{|c|}{ Cliente } & $\begin{array}{l}\text { Ano inicial de } \\
\text { exportação para o país }\end{array}$ & $\begin{array}{l}\text { Participação (\%) na } \\
\text { quantidade exportada de } \\
2003\end{array}$ \\
\hline $\begin{array}{l}\text { ( ) Países pertencentes à União } \\
\text { Européia }\end{array}$ & & \\
\hline ( ) Estados Unidos & & \\
\hline ( ) Oriente Médio & & \\
\hline ( ) Ásia & & \\
\hline $\begin{array}{l}\text { ( ) Outro. } \\
\text { Especifique: }\end{array}$ & & \\
\hline
\end{tabular}

\section{II - Aspectos Institucionais e Organizacionais}

1. Quais os programas de qualidade adotados pela empresa?

\begin{tabular}{|l|l|}
\hline \multicolumn{1}{|c|}{ Programa } & Ano de implementação na empresa \\
\hline ( ) Rastreabilidade & \\
\hline ( ) Análise de Riscos e Pontos Críticos - & \\
HACCP & \\
\hline ( ) ISO 9000 & \\
\hline ( ) Boas Práticas de Fabricação - BPF & \\
\hline ( ) Outro. Especifique: & \\
\hline
\end{tabular}

2. Qual o nível de rastreabilidade da empresa?

( ) Completa: iniciada no nascimento do animal

( ) Parcial: iniciada com o animal já vivo, sendo implantada tanto na recria como na engorda

( ) Não possui 
3. Qual a Portaria Nacional a empresa tem dificuldade em atender?

4. Quais as dificuldades da empresa em atender o SISBOV?

5. Como a doença da vaca-louca afetou a estrutura/investimentos na empresa?

6. Em relação aos clientes europeus, quais os programas de qualidade que são exigidos por eles?

\begin{tabular}{|l|l|}
\hline Programas de Qualidade Exigidos & $\begin{array}{l}\text { Ano em que a União } \\
\text { Européia exigiu }\end{array}$ \\
\hline ( )Nenhum & \\
\hline ( )Análise de Riscos e Pontos críticos de Controle de & \\
\hline ( )ISO 9000 & \\
\hline ( )Rastreabilidade: & \\
\hline Total ( ) & \\
\hline Parcial ( ) & \\
\hline Nenhum ( ) & \\
\hline ( )Boas Práticas de Fabricação (BPF) & \\
\hline
\end{tabular}

7.Quais são as principais exigências dos clientes europeus em relação à matéria-prima:

( ) Não usar hormônios

( ) Não usar ingredientes de origem animal

( ) Não usar antibióticos

( ) Outros. Especificar:

8.Existem outras exigências que os clientes europeus passarão a exigir em breve? Alguns cliente tem exigência a mais do que consta na diretiva? 


\section{III - Relação com Fornecedor}

1. Como a empresa adquire a matéria-prima boi?

\begin{tabular}{|l|}
\hline $\begin{array}{l}\text { Antes de } 1996 \text { (antes do surto } \\
\text { da vaca-louca) }\end{array}$ \\
\hline $\begin{array}{l}\text { ( ) Via compra no mercado } \\
\text { (sem contrato) de qualquer } \\
\text { produtor }\end{array}$ \\
\hline $\begin{array}{l}\text { ( ) Via contratos com } \\
\text { produtores. Especifique o tipo de } \\
\text { contrato: }\end{array}$ \\
\hline ( ) Outro modo. Especifique: \\
\hline
\end{tabular}

\begin{tabular}{|l|}
\hline $\begin{array}{l}\text { Depois de } 1996 \text { (com as exigèncias de } \\
\text { qualidade e rastreabilidade) }\end{array}$ \\
\hline $\begin{array}{l}\text { ( ) Via compra no mercado (sem contrato) } \\
\text { de qualquer produtor }\end{array}$ \\
\hline $\begin{array}{l}\text { ( ) Via contratos com produtores. } \\
\text { Especifique o tipo de } \\
\text { contrato: }\end{array}$ \\
\hline ( ) Outro modo. Especifique: \\
\hline
\end{tabular}

2. Quais as medidas ou cuidados adotados pela empresa na compra de boi em relação à doença da febre aftosa? Como essa doença atingiu a compra de boi pela empresa no ano de 2000 (foco da doença no estado do Rio Grande do Sul) e 2001 (na Grã -Bretanha)?

3. A empresa cria boi para o fornecimento próprio?

\begin{tabular}{|l|l|l|}
\hline & Por quê? & $\begin{array}{l}\text { Participação (\%) no o total } \\
\text { fornecido à empresa }\end{array}$ \\
\hline ( ) Sim & & \\
\hline ( ) Não & & \\
\hline
\end{tabular}

4. Qual o número de fornecedores da empresa?

\begin{tabular}{|l|l|l|l|}
\hline \multicolumn{2}{|c|}{ Para atender o Mercado Interno } & \multicolumn{2}{c|}{ Para atender o Mercado Externo } \\
\hline $\begin{array}{l}\mathrm{N}^{\mathrm{o}} \text { de fornecedores } \\
\text { rastreados }\end{array}$ & $\begin{array}{l}\mathrm{N}^{\mathrm{o}} \text { de fornecedores } \\
\text { não rastreados }\end{array}$ & $\begin{array}{l}\mathrm{N}^{\mathrm{o}} \text { de fornecedores } \\
\text { rastreados }\end{array}$ & $\begin{array}{l}\mathrm{N}^{\mathrm{o}} \text { de fornecedores } \\
\text { não rastreados }\end{array}$ \\
\hline & & & \\
\hline
\end{tabular}

5. Como é feita a compra do boi rastreado?

( ) Via contrato formal

( ) Sem contrato

( ) O fornecedor não aceita

6. Qual incentivo dado pela empresa ao boi rastreado?

( ) Preço

( ) Outro. Especifique: 
7. A empresa compra boi:

( ) diariamente ( ) semanalmente ( ) mensalmente ( )anualmente

8. A empresa compra boi dos mesmos fornecedores todo ano ou a cada ano os fornecedores variam muito?

9. Diante das incertezas da empresa quanto ao ambiente econômico e à matéria prima boi, relacione um grau de incerteza para cada, de acordo com a legenda abaixo:

1-Baixa

2-Média

3-Alta

\begin{tabular}{|l|l|}
\hline \multicolumn{1}{|c|}{ Incerteza } & Grau de incerteza \\
\hline ( ) Aumento no preço do boi & \\
\hline ( ) Falta de boi para compra & \\
\hline $\begin{array}{l}\text { ( ) Concorrência com outros frigoríficos } \\
\text { na compra do boi }\end{array}$ & \\
\hline ( )Outra. Qual & \\
\hline
\end{tabular}

10. Em relação ao comportamento do fornecedor:

\begin{tabular}{|l|l|}
\hline Comportamento do fornecedor de boi & $\begin{array}{l}\text { Participação (\%) no total de casos } \\
\text { ocorridos }\end{array}$ \\
\hline $\begin{array}{l}\text { ( ) Cumpre o combinado entre as partes } \\
\text { na negociação de compra do boi }\end{array}$ & \\
\hline $\begin{array}{l}\text { ( ) São poucos os casos em que o } \\
\text { fornecedor não cumpre o combinado entre } \\
\text { as partes na negociação de compra do boi }\end{array}$ & \\
\hline $\begin{array}{l}\text { ( ) A empresa sempre tem problemas com } \\
\text { o fornecedor quanto ao cumprimento do } \\
\text { combinado na negociação }\end{array}$ & \\
\hline
\end{tabular}

11. A empresa compete com outros frigoríficos na compra de boi?

12. A empresa participa de Alguma Aliança Mercadológica ou Programa de Novilho Precoce?

( ) Sim. Qual e Por quê?

( ) Não. Por quê? 
13. Quem deve ser o responsável pela coordenação e por quê? (pode assinalar mais de uma opção)

( ) Governo. Por quê?

( ) Produtores. Por quê?

( ) Frigoríficos exportadores. Por quê?

( ) Frigoríficos em geral. Por quê?

( ) Varejo. Por quê?

( ) Órgãos de classe. Por quê?

( ) Outros. Qual e Por quê?

14. Que incentivos devem ser dados para ocorrer a coordenação para frigoríficos e produtores de boi?

\section{IV - Relação com o Cliente Interno (Mercado Interno)}

1. Quais os clientes do mercado interno da empresa e a participação? (pode assinalar mais de uma alternativa)

\begin{tabular}{|l|l|}
\hline \multicolumn{1}{|c|}{ Cliente } & Participação (\%) na quantidade vendida \\
\hline Supermercado/Hipermercado & \\
\hline Boutiques de carne & \\
\hline Açougue & \\
\hline Atacado & \\
\hline Loja própria da empresa & \\
\hline Outro. Qual: & \\
\hline
\end{tabular}

2. Há contratos da empresa com o varejo na venda da carne? Que tipo e desde quando?

3. Qual a freqüência de venda da empresa (marque com X):

\begin{tabular}{|l|l|l|l|l|}
\hline \multicolumn{2}{|c|}{ Varejo } & \multicolumn{3}{c|}{ Frequência } \\
\cline { 2 - 5 } & $\begin{array}{l}\text { Diariament } \\
\mathrm{e}\end{array}$ & $\begin{array}{l}\text { Semanalment } \\
\mathrm{e}\end{array}$ & $\begin{array}{l}\text { Mensalmen } \\
\text { te }\end{array}$ & $\begin{array}{l}\text { Anualme } \\
\text { nte }\end{array}$ \\
\hline Supermercado/Hipermercado & & & & \\
\hline Boutiques de carne & & & & \\
\hline Açougue & & & & \\
\hline Atacado & & & & \\
\hline Loja própria da empresa & & & & \\
\hline Outro. Qual & & & & \\
\hline
\end{tabular}


4. A empresa sempre vende para os mesmos varejos (clientes) ou a cada ano os clientes variam muito?

5. Diante das incertezas da empresa quanto ao ambiente econômico e à venda da carne, relacione um grau de incerteza para cada, de acordo com a legenda abaixo:

1-Baixa

2-Média

3-Alta

\begin{tabular}{|l|l|}
\hline \multicolumn{1}{|c|}{ Incerteza } & Grau de incerteza \\
\hline ( ) Queda no preço da carne de boi & \\
\hline ( ) Variação da renda do consumidor & \\
\hline ( ) Concorrência com carne de frango e & \\
suína & \\
\hline ( )Outra. Qual & \\
\hline
\end{tabular}

6. Em relação ao comportamento do varejo:

\begin{tabular}{|l|l|}
\hline Comportamento do varejo & $\begin{array}{l}\text { Participação (\%) no total de casos } \\
\text { ocorridos }\end{array}$ \\
\hline $\begin{array}{l}\text { ( ) Cumpre o combinado entre as partes } \\
\text { na negociação da venda da carne }\end{array}$ & \\
\hline $\begin{array}{l}\text { ( ) São poucos os casos em que o varejo } \\
\text { não cumpre o combinado entre as partes na } \\
\text { negociação da venda da carne }\end{array}$ & \\
\hline $\begin{array}{l}\text { ( ) A empresa sempre tem problemas com } \\
\text { o varejo quanto ao cumprimento do } \\
\text { combinado na negociação }\end{array}$ & \\
\hline
\end{tabular}

\section{V - Relação com Cliente Europeu (mercado externo)}

1. A empresa exporta diretamente ou utiliza traders?

( ) utiliza traders ( ) exporta diretamente ( ) ambas

2. Desde quando a empresa exporta para a União Européia e por que optou por este mercado?

3. Tipo de carne exportada para a União Européia e participação de cada tipo:

( ) In natura. Participação:

( ) Industrializada. Participação: 
4. Quais os principais clientes europeus?

\begin{tabular}{|l|l|}
\hline Clientes europeus & Participação(\%) \\
\hline ( )Rede de supermercados & \\
\hline ( )Atacadistas & \\
\hline ( ) Empresas processadoras & \\
\hline ( ) Distribuidor & \\
\hline ( ) Outros. Quais? & \\
\hline
\end{tabular}

5. Qual a opinião da sua empresa no que se refere a estas exigências (citadas nas questões anteriores) do cliente europeu?

\begin{tabular}{|l|l|l|}
\hline \multicolumn{1}{|c|}{ Alternativas } & \multicolumn{2}{c|}{ Marque com um X } \\
\cline { 2 - 3 } & SIM & NÃO \\
\hline Estas exigências retratam a preocupação dos consumidores & & \\
\hline $\begin{array}{l}\text { Estas exigências retratam barreiras não-tarifárias (imposições } \\
\text { feitas para restringir o comércio, que na realidade não são } \\
\text { exigências dos consumidores) }\end{array}$ & & \\
\hline $\begin{array}{l}\text { Estas exigências precisam ser cumpridas para permanecer no } \\
\text { mercado europeu }\end{array}$ & & \\
\hline Outro (especificar) & & \\
& & \\
\hline
\end{tabular}

6. Quais as principais medidas adotadas pela empresa para atender as exigências de seus respectivos clientes?

\begin{tabular}{|l|}
\hline \multicolumn{1}{|c|}{ Medidas Adotadas } \\
\hline ( )Investir em pesquisa e tecnologia \\
\hline ( )Contratar mão-de-obra especializada \\
\hline ( )Passou a implantar Programas de Qualidade \\
\hline ( )Assegurar-se das fontes de fornecimento da matéria-prima \\
\hline ( )Não adotou nenhuma medida \\
\hline ( )Outro (listar): \\
\hline
\end{tabular}


7. Quais as principais demandas da empresa em relação a situação do setor público?

\begin{tabular}{|l|l|}
\hline \multicolumn{1}{|c|}{ Alternativas } & $\begin{array}{c}\text { Marque com } \\
\text { um X }\end{array}$ \\
\hline Emissão de selos de qualidade & \\
\hline Linhas de financiamento à taxa de juros acessíveis & \\
\hline Implantação e coordenação do SISBOV & \\
\hline Outros (listar) & \\
\hline
\end{tabular}

8. Há contratos da empresa com os clientes externos? Que tipo e desde quando?

9. Qual a freqüência de venda ao cliente europeu:

( ) diariamente ( ) semanalmente ( ) mensalmente ( )anualmente

10. Diante das incertezas da empresa quanto ao ambiente econômico e à venda da carne ao mercado externo, relacione um grau de incerteza para cada, de acordo com a legenda abaixo:

1-Baixa

2-Média

3-Alta

\begin{tabular}{|l|c|}
\hline \multicolumn{1}{|c|}{ Incerteza } & Grau de incerteza \\
\hline ( ) Queda brusca no preço da carne de boi & \\
\hline ( ) Alteração no câmbio & \\
\hline ( ) Imposição de barreiras sanitárias & \\
\hline ( ) Outra. Qual__ & \\
\hline
\end{tabular}

11. Em relação ao comportamento do cliente europeu:

\begin{tabular}{|l|l|}
\hline Comportamento do cliente europeu & $\begin{array}{l}\text { Participação (\%) no total de casos } \\
\text { ocorridos }\end{array}$ \\
\hline $\begin{array}{l}\text { ( ) Cumpre o combinado entre as partes } \\
\text { na negociação da venda da carne }\end{array}$ & \\
\hline $\begin{array}{l}\text { ( ) São poucos os casos em que o cliente } \\
\text { europeu não cumpre o combinado entre as } \\
\text { partes na negociação da venda da carne }\end{array}$ & \\
\hline $\begin{array}{l}\text { ( ) A empresa sempre tem problemas com } \\
\text { o cliente europeu quanto ao cumprimento } \\
\text { do combinado na negociação }\end{array}$ & \\
\hline
\end{tabular}


VI - Produção

1. Qual o número de bois abatidos pela empresa? (preencher os espaços)

\begin{tabular}{|l|l|}
\hline Ano & Abate total \\
\hline 1996 & \\
\hline 1997 & \\
\hline 1998 & \\
\hline 1999 & \\
\hline 2000 & \\
\hline 2001 & \\
\hline 2002 & \\
\hline 2003 & \\
\hline
\end{tabular}

2. Qual o número da Produção e Exportação da Empresa? (preencher os espaços)

\begin{tabular}{|c|c|c|}
\hline Ano & $\begin{array}{c}\text { Produção Total } \\
\text { US\$ }\end{array}$ & $\begin{array}{c}\text { Exportação Total } \\
\text { US\$ }\end{array}$ \\
\hline 1996 & & \\
\hline 1997 & & \\
\hline 1998 & & \\
\hline 1999 & & \\
\hline 2000 & & \\
\hline 2001 & & \\
\hline 2002 & & \\
\hline 2003 & & \\
\hline 2004 & & \\
\hline
\end{tabular}

2. Qual a exportação da empresa para a Europa?

\begin{tabular}{|c|c|}
\hline Ano & $\begin{array}{c}\text { Exportação para a União Européia } \\
\text { US\$ }\end{array}$ \\
\hline 1996 & \\
\hline 1997 & \\
\hline 1998 & \\
\hline 1999 & \\
\hline 2000 & \\
\hline 2001 & \\
\hline 2002 & \\
\hline 2003 & \\
\hline 2004 & \\
\hline
\end{tabular}


4. Faturamento Anual

( ) menos de $\mathrm{R} \$ 300$ milhões ( ) entre $\mathrm{R} \$ 301$ e $\mathrm{R} \$ 650$ milhões

( ) entre $\mathrm{R} \$ 651$ e R\$ 999 milhões ( ) mais de R\$ 1 bilhão

( ) não é possível informar

5. Origem do capital da empresa (pode marcar com X em mais de uma opção):

( ) Nacional

( ) Estrangeiro.Especifique o pais:

( ) Misto

Nome e cargo na empresa das pessoas que responderam o questionário 


\section{Apêndice 2 - Perguntas adicionais feitas nas entrevistas}

1. A empresa compra boi que seja alimentado com ração composta por transgênicos?

( ) Compra

( ) Não compra

( ) Isso não tem importância para a empresa

2. Quais os tipos de corte que a empresa exporta para a União Européia

3. Qual o nível de preocupação que a empresa tem observado por parte dos clientes europeus em relação à segurança do alimento? Nas respostas seguintes, as letras indicam os clientes.

A- Rede de supermercados

B- Atacadistas

C- Empresas processadoras

D- Distribuidor

E- Outros. Quais?

Considere o nível de preocupação de acordo com a escala abaixo:

$0=$ nenhum nível de preocupação

$1=$ baixo nível de preocupação

$2=$ médio nível de preocupação

$3=$ alto nível de preocupação

4= altíssimo nível de preocupação

\begin{tabular}{|c|l|}
\hline Cliente Europeu & $\begin{array}{l}\text { Nível de preocupação (colocar o } \mathrm{n}^{\mathrm{o}} \text { de acordo com a } \\
\text { escala descrita acima) }\end{array}$ \\
\hline A & \\
\hline B & \\
\hline C & \\
\hline D & \\
\hline E & \\
\hline
\end{tabular}

